QATAR UNIVERSITY

Graduate Studies

College of Art \& Sciences

\title{
Spatial and Temporal Distribution of Heavy Metals in Marine Sediment along the Doha Bay
}

\author{
A project in \\ Department of Biological \& Environmental Sciences \\ By \\ (C) 2013 Hajer Ammar Al-Naimi \\ Submitted in Partial Fulfillment \\ Of the Requirements \\ For the Degree of \\ Master of Science
}

June 2013 
The project of Hajer Ammar Al-Naimi was reviewed and approved by the following:

We, the committee members listed below accept and approve the project of the student named above. To the best of this committee's knowledge, the project conforms the requirements of Qatar University, and we endorse this project for examination.

Name: Dr. Mohammed Al-Ghouti

Signature Date

Name: Dr. Mehsin Al-Yafei

Signature Date

Name: Dr. Saeed Al-Meer

Signature Date

Name: Mr. Ismail Al-Shaikh

Signature Date

Name:

Signature Date

Name:

Signature Date 


\section{Abstract}

Concentrations of twenty five heavy metals ( $\mathrm{Ag}, \mathrm{Al}, \mathrm{As}, \mathrm{Ba}, \mathrm{Be}, \mathrm{Ca}, \mathrm{Cd}, \mathrm{Co}, \mathrm{Cr}$, $\mathrm{Cu}, \mathrm{Fe}, \mathrm{K}, \mathrm{Li}, \mathrm{Mg}, \mathrm{Mn}, \mathrm{Mo}, \mathrm{Na}, \mathrm{Ni}, \mathrm{Pb}, \mathrm{Sb}, \mathrm{Se}, \mathrm{Sr}, \mathrm{V}, \mathrm{Zn}$, and $\mathrm{Hg}$ ) in surface sediment from ten transects each with five stations were studied. The sediment samples were collected in May and December 2012 in order to examine the spatial and temporal variation and investigate the pollution sources. Significant differences were observed in metal concentrations between the sampling locations and durations. Higher concentrations were observed in areas where there are a lot of anthropological activities. The distribution of selected metals were presented in contour maps showing the variation between the two periods. Moreover, it was observed that December 2012 sampling was significantly higher than May 2012. In order to further study particle size effect on metals uptake, two different grinding times were administered on four randomly selected samples and the results showed no significant difference on the analysis in the ICP-OES instrument. The overall results of metal analyses were within the international standards criteria and the results were comparable to the previous studies conducted around Qatar. A monitoring approach is recommended for the sediment quality assessment. Additional examinations were conducted using contour maps that show the distributions of the metals around Doha Bay during May and December 2012. 


\section{LIST OF ABBREVIATIONS}

A list of some common abbreviations used in this report is provided below.

AVS -Acid Volatile Sulfides

BOD- Biological Oxygen Demand

CCV - Continuous Calibration Verification

CRM - Certified Reference Material

ERL - Effects Low Range

ERM - Effects Range-Moderate

ICP-OES - Inductively Coupled Plasma Optical Emission Spectrophotometer ICV - Initial Calibration Verification

LOQ - Limit of Quantitation

PAH - Polycyclic Aromatic Hydrocarbons

PEL - Probable Effects Level

SBOD - Sediment Biochemical Oxygen Demand

SQG - Sediment Quality Guideline

TEL - Threshold Effects Level

TPH - Total Petroleum Hydrocarbons

VOC - Volatile Organic Compounds 


\section{TABLE OF CONTENTS}

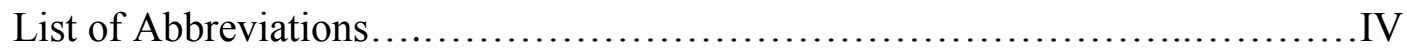

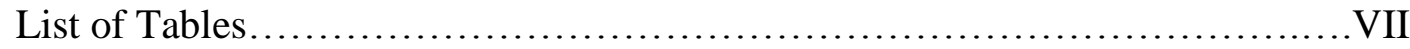

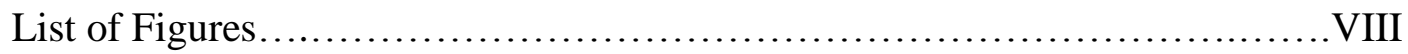

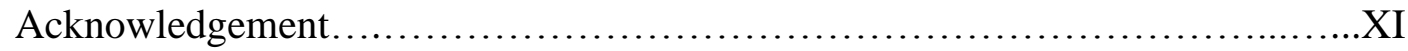

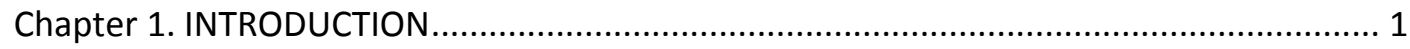

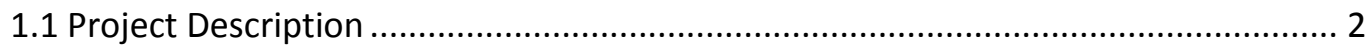

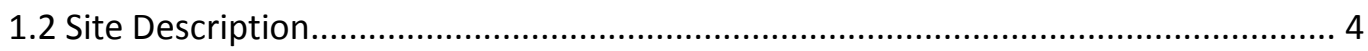

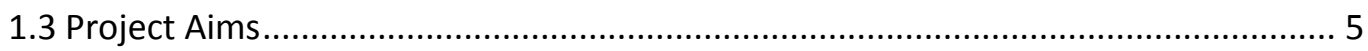

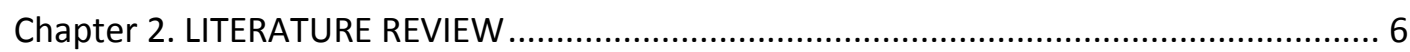

2.1 Heavy Metals, Uses and Sources ............................................................. 8

2.2 Contamination and Pollution in the Marine Environment................................... 13

2.2.1 An Overview of Marine Pollution .................................................... 13

2.3 Heavy Metals Pollution in Sediments ........................................................ 14

2.3.1 Effects of Heavy Metals Contamination in Sediments ............................... 15

2.4 potential Heavy metals contamination associated with impounded water systems:

2.5 Assessment of Contaminated Sediments ................................................... 27

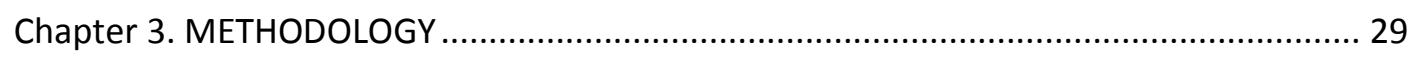

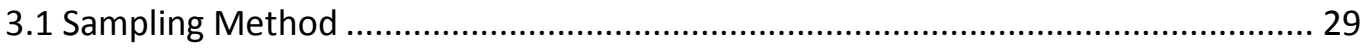

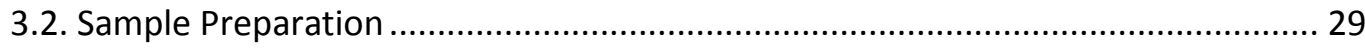

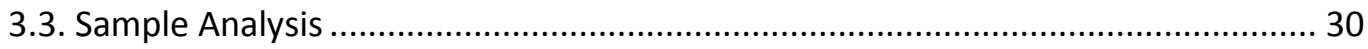

3.4. Quality Control Measures..................................................................... 30

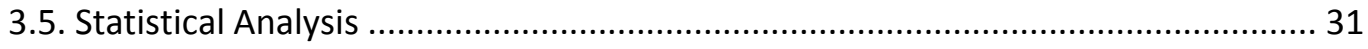

Chapter 4. RESULTS AND DISCUSSION ............................................................. 35

4.1 Spatial Variation of the Metals Concentration ................................................. 36

4.2 Seasonal Variation of the Metals Concentration ............................................. 43

4.3 Size Analysis for Sediment Samples ........................................................... 51

4.4 Comparison to International Guidelines and Previous Studies............................. 57

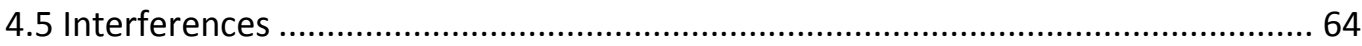




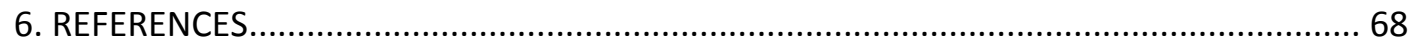

7. Appendix A : Results of Metal Analyses ...................................................................... 79

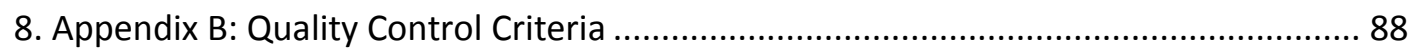

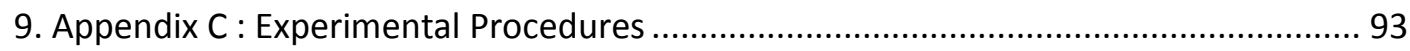

10. Appendix D : Contour Maps of Selected Heavy Metals............................................. 108

11. Appendix E : Images of Equipment and Instruments ............................................. 118 


\section{LIST OF TABLES}

$\underline{\text { Table }}$

$\underline{\text { Page }}$

Table.1. Details of the sampling locations and depth

3

Table 2: Details about selected heavy metals .11

Table.3: Comparison of average metals concentration recorded in sediment samples surrounding Doha Bay during May and December 2012 sampling....

Table 4: International sediment quality guidelines summarized for consideration of contaminant levels analyzed within Doha Bay during May and December 2012 sampling.

Table 5: Metal concentrations recorded in sediments from the different locations. 


\section{LIST OF FIGURES}

$\underline{\text { Figure }}$

$\underline{\text { Page }}$

Figure 1. Map showing the studies locations................................4

Figure 2: Orakei Basin, Auckland, New Zealand.............................25

Figure 3: The Pearl Qatar project........................................25

Figure 4: a diagram of Orakei basin illustrating the

massive formation of black mud..............................................27

Figure 5: Contour Map showing the distribution of

Zinc metal around Doha Bay during May 2012...............................39

Figure 6: Contour Map showing the distribution of

Zinc metal around Doha Bay during December 2012 .........................40

Figure 7: Contour Map showing the distribution of

Vanadium metal around Doha Bay during May 2012........................41

Figure8: Contour Map showing the distribution of

Vanadium metal around Qatari Bay during December 2012 ....................42

Figure9: Aluminum concentration recorded from the sediment samples collected around Doha Bay during May and December 2012 sampling ....................................... 45

Figure 10 : Barium concentration recorded from the sediment samples collected around Doha Bay during May and December 2012 sampling.........................................45

Figure 11: Cadmium concentration recorded from the sediment samples collected around Doha Bay during May and December 2012 sampling .......................................46

Figure 12: Chromium concentration recorded from the sediment samples collected around Doha Bay during May and December 2012 sampling.

Figure 13: Copper concentration recorded from the sediment samples collected around Doha Bay during May and December 2012 sampling.... 
Figure 14: Potassium concentration recorded from the sediment samples collected around Doha Bay during

Figure 15: Nickel concentration recorded from the sediment samples collected around Doha Bay during May and December 2012 sampling.

Figure 16: Antimony concentration recorded from the sediment samples collected around Doha Bay during May and December 2012 sampling.

Figure 17: Zinc concentration recorded from the sediment samples collected around Doha Bay during May and December 2012 sampling. ...

Figure 18: Comparison of metal concentrations of stations A3, D3, E1, and I1 under 15-min and 30-min grinding time

Figure 19 : Particle size distribution of station A3/30 min. .55

Figure 20 : Particle size distribution of station A3/15 min. .55

Figure 21 : Particle size distribution of station D3/30 min .55

Figure.22 : Particle size distribution of station D3/15 min.

Figure 23: Particle size distribution of station E1/30 min. .56

Figure 24 : Particle size distribution of station E1/15 min. .56

Figure25 : Particle size distribution of station I1/30 min. .57

Figure 26 : Particle size distribution of station I1/15 min. .57

Figure 27: Cadmium concentration from sediment samples compared with international standard recorded during May and December 2012 sampling....

Figure 28: Chromium concentration from sediment samples compared with international standard recorded during May and December 2012 sampling...

Figure 29: Copper concentration from sediment samples compared with international standard recorded during May and December 2012 sampling. 
Figure 30: Nickel concentration from sediment samples compared with international standard recorded during May and December 2012 sampling..................................61

Figure 31: Zinc concentration from sediment samples compared with international standard recorded during May and December 2012 sampling.

Figure 32: Mercury concentration from sediment samples compared with international standard recorded during May and December 2012 sampling.... .62 


\section{ACKNOWLEDGEMENTS}

I would like to gratefully acknowledge the enthusiastic supervision of Dr. Mohammed Al-Ghouti during this work. I also wish to thank Mr. Ismail Al-Shaikh for his invaluable assistance, support and guidance. Deepest gratitude are also due to the rest of the supervisory committee, Dr. Mehsin Al-Yafei and Dr. Saeed AlMeer without whose knowledge and assistance this study would not have been successful. I would also like to convey thanks to the management and faculty of the Environment Studies Center, Qatar university for providing the laboratory facilities and technical support. Finally, I wish to express my love and gratitude to my beloved family; for their understanding and endless love, through the duration of my studies. 


\section{Chapter 1. INTRODUCTION}

Pollution by heavy metals in natural environments has become a global problem (Irabien and Velasco, 1999). Heavy metals are of considerable environmental concern due to their toxicity, wide sources, non-biodegradable properties, and accumulative behaviors. With the rapid industrialization and economic development in the east coastal region of Qatar, especially in the Doha bay area, heavy metals are continuing to be introduced to estuarine and coastal environment through runoff, non-point sources, and land-based point sources where metals are produced as a result of metal refinishing by-products (Malins, et al. 1984). When metals enter into the marine environment, most of them will settle down and be incorporated into sediments together with organic matters, Fe/Mn oxides, sulfides, and clay (Wang and Chen, 2000). Marine sediments act as scavengers for trace metals and often provide an excellent proof of man's impact (Guevara et al., 2005). To some extent, trace metal contents in sediment can reflect the quality of the water body. Although sediments act as one of the ultimate sinks for heavy metals input into the aquatic environment, they cannot fix metals permanently. Some of the sediment bound metals might be released into the water body again through various processes of remobilization under variable conditions (Allen 1995). Therefore, sediments are the main repository and source of heavy metals in the marine environment and play an important role in the transport and storage of potentially hazardous metals. 


\subsection{Project Description}

This project is a part of an environmental assessment project that is carried out by the Environmental Studies Center (ESC), Qatar University. The project aimed at producing a baseline study to provide knowledge on the environmental characteristics and properties in the location where many developments are constructed such as residences, marinas and other facilities within the coast of Doha Bay. This part which this study is concerned, is to investigate metals concentration within the area. This bay is categorized as an impounded water body which is isolated partially or totally from the main water system due to human intervention (e.g. urbanization). This kind of water system may lay beneath many speculated environmental problems such as: water stratification, high biological oxygen demand (BOD), siltation (release of mud and silt-sized sediment to the water) which increase the heavy metal load attracted by silts, change of $\mathrm{pH}$ as more organic contents increase the water becomes more acidic, increase in salinity due to higher evaporation and less water movement, increase in nutrient as more $\mathrm{P}$ (phosphorous) and $\mathrm{N}$ (Nitrogen) would be added to the water body with minimum recharging, accumulation of heavy metals, accumulation of organic pollutants, death of the native species, introduction of new exotic species, deterioration of water quality, and value loss of estates (Denton, et al. 2001). According to the contract between Lusail Real Estate Development and ESC, those were some of the major reasons for conducting such a study. For the heavy metal analysis part of the study, 50 marine sediment samples for two time periods (May and December 2012) were collected from selected sites located at the 
coastal area north of Doha, north of the Pearl, and south of Al Safeliya on the eastern coast of Qatar. These samples are subjected to simultaneous determination of minerals and heavy metals (Ag, $\mathrm{Al}, \mathrm{As}, \mathrm{Ba}, \mathrm{Be}, \mathrm{Ca}, \mathrm{Cd}, \mathrm{Co}, \mathrm{Cr}, \mathrm{Cu}, \mathrm{Fe}, \mathrm{K}, \mathrm{Li}$, $\mathrm{Mg}, \mathrm{Mn}, \mathrm{Mo}, \mathrm{Na}, \mathrm{Ni}, \mathrm{Pb}, \mathrm{Sb}, \mathrm{Se}, \mathrm{Sr}, \mathrm{V}, \mathrm{Zn}$ and $\mathrm{Hg}$ ) using Inductively Coupled Plasma-Optical Emission Spectrometry (ICP-OES). The two sampling times are called phase I and phase II; respectively. Table $1 \&$ Figure 1 show the locations and the details of the 50 stations.

Table 1. Details of the sampling locations and depth(m).

\begin{tabular}{|c|c|c|c|c|c|c|c|}
\hline Location & Latitude_X & Longitude_Y & Depth & Location & Latitude_X & Longitude_Y & Depth \\
\hline $\mathbf{A 1}$ & 232348 & 409257 & 3.1 & F1 & 232184 & 398247 & 2.8 \\
\hline$\overline{A 2}$ & 233299 & 409482 & 3.2 & F2 & 233174 & 398383 & 2.7 \\
\hline A3 & 234288 & 409711 & 7.3 & F3 & 234165 & 398519 & 3.9 \\
\hline A4 & 235255 & 409934 & 9.2 & F4 & 235156 & 398656 & 6.5 \\
\hline A5 & 236251 & 410164 & 12.1 & F5 & 236146 & 398792 & 5.7 \\
\hline$\overline{\text { B1 }}$ & 232464 & 407097 & 0.4 & G1 & 232917 & 397150 & 2.8 \\
\hline$\overline{\text { B2 }}$ & 233415 & 407292 & 3 & G2 & 233880 & 397420 & 0.9 \\
\hline$\overline{\text { B3 }}$ & 234416 & 407484 & 7 & G3 & 234843 & 397690 & 7 \\
\hline B4 & 235386 & 407669 & 2.6 & G4 & 235806 & 397961 & 6.4 \\
\hline B5 & 236386 & 407862 & 0.6 & G5 & 236769 & 398231 & 7.3 \\
\hline $\mathrm{C1}$ & 232782 & 405113 & 0.3 & H1 & 230789 & 395254 & 1.5 \\
\hline $\mathrm{C2}$ & 233761 & 404993 & 3.3 & H2 & 231746 & 395547 & 2.5 \\
\hline $\mathrm{C3}$ & 234769 & 404859 & 0.4 & H3 & 232702 & 395839 & 2 \\
\hline $\mathrm{C5}$ & 236719 & 404596 & 0.6 & H4 & 233658 & 396131 & 5.2 \\
\hline $\mathrm{C4}$ & 235746 & 404728 & 0.6 & H5 & 234614 & 396424 & 6.4 \\
\hline D1 & 233582 & 403627 & 0.3 & I1 & 231020 & 393796 & 2.7 \\
\hline D2 & 234553 & 403437 & 2 & I2 & 231917 & 394239 & 2.3 \\
\hline D3 & 235541 & 403225 & 7.6 & I3 & 232813 & 394682 & 5.7 \\
\hline D4 & 236514 & 403022 & 7.6 & I4 & 233709 & 395126 & 5.8 \\
\hline D5 & 237490 & 402799 & 2.2 & I5 & 234606 & 395569 & 8 \\
\hline E1 & 231706 & 400509 & 1 & $\mathbf{J 1}$ & 236056 & 393945 & 0.3 \\
\hline E2 & 232709 & 400405 & 3.9 & $\mathbf{J 2}$ & 236426 & 394874 & 8.9 \\
\hline $\mathbf{E 3}$ & 233720 & 400269 & 4.8 & J3 & 236795 & 395803 & 8.4 \\
\hline E4 & 234701 & 400164 & 4.4 & J4 & 237165 & 396732 & 8.5 \\
\hline$\overline{\text { E5 }}$ & 235703 & 400039 & 0.3 & J5 & 237535 & 397662 & 5.5 \\
\hline
\end{tabular}




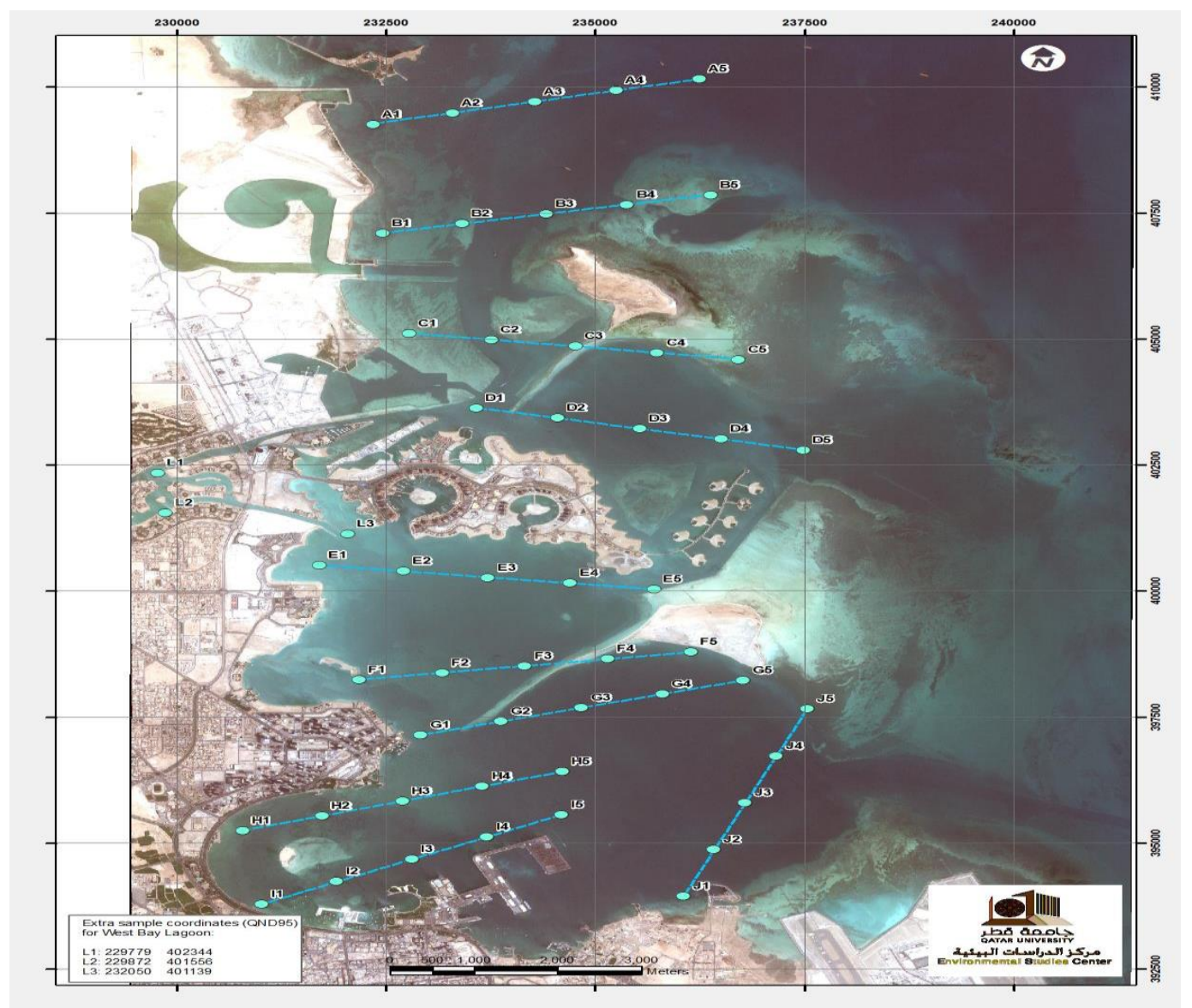

Figure 1. Map showing the studied locations (Total number of samples is 100). Source: $\mathrm{ESC} / \mathrm{QU}$

\subsection{Site Description}

The selected site of the study stretches the whole bay of Qatar comprising the coastal area north of Doha, north of the Pearl and south of Al Safeliya on the eastern coast of country. This area is under on-going development by Lusail Real Estate Development Company where coastal residences inclusive of a number of facilities will be developed. Major construction work on channels for a marina and work on the seafloor will be materialized. The impact of these activities will result in environmental stresses. To ensure a factual knowledge on the area, this study is realized and designed as a baseline impact assessment analysis which will be used 
as reference for future studies within the area.

The scope of the work details the survey of the area in terms of metal contaminants. Other important factors which may influence the contaminant level is also evaluated especially the siltation at the site, sea current and waves since the latter two affect siltation and in the case of dredging work on the seabed and sedimentation. All of these affect and pose impact on marine life and reduce the aesthetic value of the intended establishment. Slow current will cause a formation of a lagoon which will cause water stagnation and fouling. Both are undesirable in a residential location (Güven and Akınc1 2008).

Field monitoring is performed and data will be studied in detail to enable modeling. Monitoring of physico-chemical parameters is based on the baseline studies of all parameters.

\subsection{Project Aims}

- To present a competent and practical baseline review of the concentrations of 25 minerals and heavy metals (Ag, Al, As, Ba, Be, Ca, Cd, Co, Cr, Cu, Fe, K, Li, $\mathrm{Mg}, \mathrm{Mn}, \mathrm{Mo}, \mathrm{Na}, \mathrm{Ni}, \mathrm{Pb}, \mathrm{Sb}, \mathrm{Se}, \mathrm{Sr}, \mathrm{V}, \mathrm{Zn}$, and $\mathrm{Hg}$ ) in the marine sediments of the Doha bay, Qatar.

- To explore the main difficulties that may face metals measurements using ICPOES with low and high metal concentrations and how to overcome these difficulties.

- To investigate the metal concentrations at different grinding time of the sediment in order to ascertain if there is any correlation between the metal levels and grain size of the samples taken. 


\section{Chapter 2. LITERATURE REVIEW}

Sediments are essential and integral parts of water systems. They provide the substrate for organisms and through interaction with the overlying waters play an essential role in the aquatic ecosystem (Burden, et al. 2002). They are increasingly recognized as both a carrier and a possible source of contaminants in aquatic systems, and these materials may also affect groundwater quality and agricultural products when disposed on land. Contaminants are not necessarily fixed permanently by the sediment, but may be recycled via biological and chemical agents both within the sedimentary compartment and the water column. Bioaccumulation and food chain transfer may be strongly affected by sedimentassociated proportions of pollutants ((Begum, et al. 2009). Benthic organisms, in particular, have direct contact with sediment, and the contaminant level in the sediment may have greater impact on their survival than do aqueous concentrations (Malins, et al. 1984).

They are also an important repository for metal pollutants that enter the sea. Sediments provide habitats for many aquatic organisms and also a major repository for many of the more persistent chemicals that are introduced into surface waters. In the aquatic environment, most anthropogenic chemicals and waste materials including toxic organic and inorganic chemicals eventually accumulate in sediments. In aquatic environments, many heavy metals are transported predominantly in association with particulate matter, and consequently, a high concentration of heavy metals is often detected in sediments 
in many industrialized harbors and coastal regions around the world (Miller, et al. 2000, Chen, et al. 2001; Feng, et al. 2004; Wang, et al. 2007).

Contaminated sediments are crucial indicators of pollution in aquatic environments and can be defined as soils, sand, organic matter, or minerals accumulated at the bottom of a water body (USEPA 1998). Contaminants contained in sediments can be released to overlying waters and sediments can be important sources of contaminants in waters (Allen 1995; Güven and Akıncı 2008). Many of the sediments in seas, rivers, lakes, and oceans have been contaminated by pollutants. These pollutants are directly discharged by industrial plants and municipal sewage treatment plants, others come from polluted runoff in urban and agricultural areas, and some are the result of historical contamination (Begum, et al. 2009; Pempkowiak, et al. 1999). Contaminated sediments can threaten creatures in the marine environment. Some kinds of toxic sediments kill benthic organisms, reducing the food available to larger animals such as fish. Some contaminants in the sediment are taken up by benthic organisms in a process called bioaccumulation. When larger animals feed on these contaminated organisms, the toxins are taken into their bodies, moving up the food chain in increasing concentrations in a process known as bio-magnification. As a result, fish and shellfish, waterfowl, and freshwater and marine mammals may accumulate hazardous concentrations of toxic chemicals (Begum, et al. 2009).

Bottom sediments are known to act as a sink for heavy metals introduced to the sea and ocean by river runoff and dry and wet atmospheric depositions (Aksu, et al. 1998). Contaminated sediments do not always remain at the bottom of a water 
body. Anything that stirs up the water, such as dredging, can re-suspend sediments. Re-suspension may mean that all of the animals in the water, and not just the bottom-dwelling organisms, will be directly exposed to toxic contaminants. Different aquatic organisms often respond to external contamination in different ways, where the quantity and form of the element in water, sediment, or food will determine the degree of accumulation (Begum, et al. 2008). Many dangerous chemical elements, if released into the environment, accumulate in the soil and sediments of water bodies. Under certain conditions, chemical elements accumulated in the silt and bottom sediments of water bodies can migrate back into the water. Silt can become a secondary source of heavy metal pollution (Begum, et al. 2009).

\subsection{Heavy Metals, Uses and Sources}

Metals are natural constituents of rocks, soils, sediments, and water. However, over the 200 years following the beginning of industrialization huge changes in the global budget of critical chemicals at the earth's surface have occurred, challenging those regulatory systems which took millions of years to evolve (Wood and Wang 1983). The heavy metal content of sediments comes from natural sources (rock weathering, soil erosion, dissolution of water-soluble salts) as well as anthropogenic sources such as municipal wastewater-treatment plants, manufacturing industries, and agricultural activities etc. (Güven and Akınc1 2008).

The metals must be both abundant in nature and readily available as soluble species. Abundance generally restricts the available metals to those of atomic numbers below 40, some of which are virtually unavailable due to the low 
solubility of their hydroxides. Viewed from the standpoint of environmental pollution, metals may be classified according to three criteria (Wood 1974);

(i) Noncritical (Na, Mg, Fe, K, Ca, Al, Sr, Li, Rb),

(ii) Toxic but very insoluble or very rare (Ti, Hf, Zr, W, Ta, Ga, La, Os, Ir, Ru, $\mathrm{Ba}, \mathrm{Rh})$, and

(iii) Very toxic and relatively accessible (Be, $\mathrm{Co}, \mathrm{Ni}, \mathrm{Cu}, \mathrm{Zn}, \mathrm{Sn}, \mathrm{Cr}, \mathrm{As}, \mathrm{Se}, \mathrm{Te}$, $\mathrm{Ag}, \mathrm{Cd}, \mathrm{Hg}, \mathrm{Tl}, \mathrm{Pb}, \mathrm{Sb}, \mathrm{Bi})$.

Environmental pollution with toxic metals is becoming a global phenomenon. As a result of the increasing concern with the potential effects of the metallic contaminants on human health and the environment, the research on fundamental, applied and health aspects of trace metals in the environment is increasing (Vernet 1991).

Advances in information of the distributions and concentrations of trace metals in the marine environment have occurred since the mid-1970s (Burton and Statham 2000). This is mainly due to developments in procedures for contamination free sampling, the adoption of clean methodologies for handling and analysis of samples, and increased application of improved analytical methods such as inductively coupled plasma-mass spectrometry (ICP-MS) (Burton and Statham 2000; Plant, et al. 2003).

Heavy metals occur naturally as they are components of the lithosphere and are released into the environment through volcanism and weathering of rocks (Fergusson 1990). However, large-scale release of heavy metals to the aquatic 
environment is often a result of human intervention (Mance 1987; Denton, et al. 1997). Coastal regions are some of the most sensitive environments and yet they are subject to growing human pressures (David 2003) because of increasing urbanization, industrial development, and recreational activities. Therefore, pollution levels are often elevated in the coast because of nearby land based pollution sources (Fergusson 1990; Wang, et al. 2007). Industrial processes that release a variety of metals into waterways include mining, smelting and refining. Almost all industrial processes that produce waste discharges are potential sources of heavy metals to the aquatic environment (Denton, et al. 2001). Domestic wastewater, sewage sludge, urban runoff, and leachate from solid waste disposal sites are also obvious sources of heavy metals into rivers, estuaries and coastal waters (Mance 1987). A proportion of the total anthropogenic metal input in the sediments in near shore waters, adjacent to urban and industrial growth centers comes from the combustion of fossil fuels. Other potential sources include ports, harbors, marinas and mooring sites, also subjected to heavy metal inputs associated with recreational, commercial, and occasionally, military, boating, and shipping activities (Denton, et al. 1997). Table 2 shows important facts about some heavy metals. 
Table 2. Details about selected heavy metals.

\begin{tabular}{|c|c|c|c|c|}
\hline Metal & $\begin{array}{l}\text { Average } \\
\text { concentration } \\
\text { in sediment }\end{array}$ & Sources & Factors & References \\
\hline $\begin{array}{l}\text { Cadmium } \\
\text { (Cd) }\end{array}$ & $\approx 0.1 \mu \mathrm{g} / \mathrm{g}$ & $\begin{array}{l}\text { Metallurgical industries, } \\
\text { municipal effluents, sewage } \\
\text { sludge, mine wastes, fossil } \\
\text { fuels and some phosphorus } \\
\text { containing fertilizers. }\end{array}$ & $\begin{array}{l}\text { Size and density of } \\
\text { sediment, PH, acidity, } \\
\text { redox conditions and } \\
\text { complexing agents. }\end{array}$ & $\begin{array}{l}\text { Denton, et al. } \\
\text { 1997; Fergusson } \\
\text { 1990; Finkelman } \\
\text { 2005. }\end{array}$ \\
\hline $\begin{array}{l}\text { Chromium } \\
\text { (Cr) }\end{array}$ & $\approx 69 \mu \mathrm{g} / \mathrm{g}$ & $\begin{array}{l}\text { Input from rivers, urban } \\
\text { runoff, domestic and } \\
\text { industrial wastewaters, } \\
\text { sewage sludge and } \\
\text { electroplating and metal } \\
\text { finishing industry. }\end{array}$ & $\begin{array}{l}\text { volcanic eruptions and } \\
\text { PH. }\end{array}$ & $\begin{array}{l}\text { Denton, et al. } \\
\text { 1997; Fergusson } \\
\text { 1990; Finkelman } \\
2005 .\end{array}$ \\
\hline $\begin{array}{l}\text { Cobalt } \\
\text { (Co) }\end{array}$ & $20-25 \mu \mathrm{g} / \mathrm{g}$ & $\begin{array}{l}\text { Wind-blown dust, seawater } \\
\text { spray, volcanoes, forest } \\
\text { fires, continental and } \\
\text { marine biogenic emissions, } \\
\text { burning of fossil fuels, } \\
\text { sewage sludge, phosphate } \\
\text { fertilizers, mining and } \\
\text { smelting of cobalt ores, } \\
\text { processing of cobalt alloys, } \\
\text { and industries that use or } \\
\text { process cobalt compounds }\end{array}$ & $\begin{array}{l}\mathrm{PH}, \text { redox conditions, } \\
\text { ionic strength, } \\
\text { dissolved organic } \\
\text { matter concentrations } \\
\text { and presence of } \\
\text { organic ligands }\end{array}$ & $\begin{array}{l}\text { Barceloux 1999; } \\
\text { Smith and Carson } \\
1981\end{array}$ \\
\hline $\begin{array}{l}\text { Copper } \\
\text { (Cu) }\end{array}$ & $\approx 39 \mu \mathrm{g} / \mathrm{g}$ & $\begin{array}{l}\text { Mining, smelting, domestic } \\
\text { and industrial wastewaters, } \\
\text { steam electrical production, } \\
\text { incinerator emissions, } \\
\text { dumping of sewage sludge } \\
\text { and algaecides and } \\
\text { antifouling paints. }\end{array}$ & $\begin{array}{l}\text { Manganese oxides } \\
\text { containing sediment } \\
\text { And high organic } \\
\text { matter containing } \\
\text { sediment. }\end{array}$ & $\begin{array}{l}\text { Denton, et al. } \\
\text { 1997; Finkelman } \\
2005 .\end{array}$ \\
\hline
\end{tabular}


Cont. Table 2:

\begin{tabular}{|c|c|c|c|c|}
\hline Metal & $\begin{array}{l}\text { Average } \\
\text { concentration } \\
\text { in sediment }\end{array}$ & Sources & Factors & References \\
\hline $\begin{array}{l}\text { Manganese } \\
\text { (Mn) }\end{array}$ & $\approx 330 \mathrm{mg} / \mathrm{kg}$ & $\begin{array}{l}\text { Leaching from the soil and } \\
\text { Deposition from } \\
\text { atmosphere }\end{array}$ & $\begin{array}{l}\text { Size and density of } \\
\text { sediment and } \mathrm{PH} \text {. }\end{array}$ & $\begin{array}{l}\text { NAS 1973; Rope, } \\
\text { et al. 1988; } \\
\text { Windholz } 1983 .\end{array}$ \\
\hline Nickel (Ni) & $\approx 55 \mu \mathrm{g} / \mathrm{g}$ & $\begin{array}{l}\text { Discharge of municipal } \\
\text { wastewater, smelting and } \\
\text { the refining of nonferrous } \\
\text { metals and mine drainage } \\
\text { effluents. }\end{array}$ & $\begin{array}{l}\text { Presence of sulfides } \\
\text { under anaerobic } \\
\text { conditions and } \\
\text { presence of co- } \\
\text { precipitate } \mathrm{Ni}(\mathrm{OH})_{2}(\mathrm{~s}) \\
\text { under aerobic } \\
\text { conditions. }\end{array}$ & $\begin{array}{l}\text { Denton, et al. } \\
\text { 2001; Finkelman } \\
2005\end{array}$ \\
\hline Lead $(\mathbf{P b})$ & $15-50 \mu \mathrm{g} / \mathrm{g}$ & $\begin{array}{l}\text { Manufacturing processes, } \\
\text { atmospheric deposition, } \\
\text { domestic wastewaters } \\
\text { sewage and sewage sludge. }\end{array}$ & $\begin{array}{l}\text { Manganese oxides } \\
\text { containing sediment } \\
\text { and } \mathrm{PH}\end{array}$ & $\begin{array}{l}\text { Denton, et al. } \\
1997\end{array}$ \\
\hline Zinc (Zn) & $\approx 80 \mu \mathrm{g} / \mathrm{g}$ & $\begin{array}{l}\text { Discharge of domestic } \\
\text { wastewaters; coal-burning } \\
\text { power plants; } \\
\text { manufacturing processes } \\
\text { involving metals; } \\
\text { atmospheric fallout, } \\
\text { nonferrous metals, burning } \\
\text { of fossil fuels, municipal } \\
\text { wastes, fertilizer and } \\
\text { cement production. }\end{array}$ & $\begin{array}{l}\text { Presence of lead and } \\
\text { cadmium and PH }\end{array}$ & $\begin{array}{l}\text { Denton, et al. } \\
\text { 1997; Denton, et } \\
\text { al. 2001; } \\
\text { Finkelman } 2005\end{array}$ \\
\hline
\end{tabular}




\subsection{Contamination and Pollution in the Marine Environment}

Coastal areas provide important benefits to humans in terms of food resources and ecosystem services. At the same time, human activities here may have significant negative impacts on the health of ecosystems and the viability of resources. Therefore, coastal and marine pollution control is required to predict and monitor the consequences of human activities on marine and estuarine ecosystems (David 2003).

Today, the world and particularly Europe are concerned with the pollution of marine environments, which result in instant and long-term damages to coastal and marine habitats and ecosystems (Valentukevičienè and Brannvall 2008). It is thus increasingly urgent to develop new solutions for reducing pollution.

\subsubsection{An Overview of Marine Pollution}

Both contamination and pollution involve the disturbance of the natural state of the environment by anthropogenic activity. The two terms are distinguishable by the severity of the effect: pollution induces the loss of potential resources (Goldberg 1992).

In the marine environment, human-induced disturbances take many forms. Owing to source strengths and pathways, the greatest effects tend to be in the coastal zone. Waters and sediments in such regions bear the main blow of industrial and sewage discharges and are subject to spoil dumping (Hester and Harisson 2000). Contaminants are introduced into coastal environments from multiple anthropogenic sources. In urban areas a significant proportion of the contaminant load is introduced in solution, through urban storm water runoff and effluent 
discharge (Matthai, et al. 2002; Brown and Peake 2006). Many contaminants have low water solubility (Olsen, et al. 1982). When these contaminants once introduced into surface waters rapidly adsorb to suspended sediment and organic matter and are in this manner scavenged from the water column through flocculation, coagulation and sedimentation (Huh, et al. 1992; Honeyman and Santschi 1988; Hatje, et al. 2003).

\subsection{Heavy Metals Pollution in Sediments}

Major indicators of pollution in aquatic environments are contaminated sediments that can be defined as soils, sand, organic matter, or minerals accumulated at the bottom of a water body (USEPA 1998). Under certain conditions, contaminants found in sediments can be released to waters and thus, sediments can be important sources of the contaminants in waters (Allen 1995).

Marine sediments constitute part of the contaminants in aquatic environments. The bottom sediment serves as a reservoir for heavy metals, and therefore, deserves special consideration in the planning and design of aquatic pollution research studies. Heavy metals such as $\mathrm{Cd}, \mathrm{Hg}, \mathrm{Pb}, \mathrm{Cu}$, and $\mathrm{Zn}$, are regarded as serious marine pollutants because of their toxicity, tendency to be incorporated into food chains, and ability to remain in an environment for a long time (Puyate, et al. 2007). The concentration of heavy metals in sediments can be influenced by variation in their texture, composition, reduction/oxidation reactions, adsorption/desorption, and physical transport or sorting in addition to anthropogenic input (Basaham and El-Sayed 1997). Potentially, toxic compounds, especially heavy metals, are adsorbed on mineral or organic particles either in 
their organic or inorganic forms (Forstner and Wittman 1983; Kabata-Pendias and Pendias 2000). Studies on the distribution of trace metals in sediments and other media are of great importance in the context of environmental pollution (Howari 2005).

Sediments of rivers, lakes and estuaries in a large number of locations have been contaminated by inorganic and organic materials. Among the inorganic materials, metals are frequent and important contaminants in aquatic sediments. They are involved in a number of reactions in the system including sorption and precipitation, and they are greatly influenced by redox conditions in the sediments (Allen 1995). Heavy metals are transported as either dissolved species in water or an integral part of suspended solids. They may be volatilized to the atmosphere or stored in riverbed sediments. They can remain in solution or suspension and precipitate on the bottom or can be taken up by organisms (Topcuoglu, et al. 2002).

\subsubsection{Effects of Heavy Metals Contamination in Sediments}

Heavy metals are preferentially transferred from the dissolved to the particulate phase and these results in the elevation of metal concentrations in estuaries and marine sediments. Therefore, concentrations often exceed those in overlying water by several orders of magnitude (Langston 2000). Since sediments can accumulate heavy metals, concentrations can be high and become potentially toxic (Williamson, et al. 2003). Exposure and uptake of even a small fraction of sediment-bound metal by organisms could have significant toxicological significance, in particular where conditions favor bioavailability. In addition, 
increased metal concentrations in pore water may contribute significantly to sediment toxicity (Langston 2000).

Binning and Baird (2001) reported that many of the metals have no known biological function in the marine environment, but can act together with other chemical species to increase toxicity. The potential effects of accumulating levels of heavy metals can be estimated by comparing the concentrations of contaminants of interest present in sediments with sediment quality guidelines (SQGs) (Williamson, et al. 2003). The Sediment Quality Guidelines

(SQGs) have been derived from large databases, which correlate the incidence of adverse biological effects with the concentrations of contaminants in sediments (Long, et al. 1995). They are used in the evaluation of sediment contamination and potential ecotoxicological effects.

There are two levels of risks considered under this SQG - effects low range (ERL) and effects range-moderate (ERM) (Guerra-Garcia and Garcia-Gomez 2005). Concentrations below the ERL value are rarely associated with biological effects while concentrations above the ERL but below the ERM indicate a possible range in which effects would occur occasionally. Concentrations above ERM are associated with frequent adverse ecological effects on the benthic communities. The effect of heavy metal contaminants in the sediment on benthic organisms can be either acute or chronic (Binning and Baird 2001). No matter whether metals are essential or not, all heavy metals form an important group of enzyme inhibitors when natural concentrations are exceeded. Therefore, organisms living in or adjacent to metal contaminated sediments may suffer toxic effects that can be fatal in highly contaminated situations (Denton, et al. 2001). In addition, metal 
enrichment in estuaries and coastal environments is a major concern as heavy metals have the ability to bio-accumulate in the tissues of various biotas (Binning and Baird 2001).

A wide range of criteria to find the impact of metals on marine organisms have been developed during the last few years (Chandra 2002). Growth, reproduction, and recruitment are usually the processes most susceptible to metal stress. Heavy metal contamination has become a subject of public interest because humans have been harmed by metal contamination (Chandra 2002).

The toxicity of a trace element to an organism depends on the metal chemical species, its concentration and the organism being affected. As for the organism, toxic effects occur when excretory, metabolic, storage, and detoxicification mechanisms no longer have the capacity to match uptake rates. This capacity may vary between species, populations, even individuals and can also depend on the stage in the life history of the organism (Langston 2000). The consumption of marine food is the principal path to human exposure to heavy metals. Effects on humans can be observed after either a one-off exposure to a large non-lethal dose (acute) or after repeated exposure to lower dose (chronic) (Redfern 2006).

Enrichment of trace metals from anthropogenic sources in the estuaries and marine environments has become a serious human health and environmental concern. Once trace metals are deposited in sediments, they undergo a series of physical, biological and chemical processes. Trace metals occur in a number of different forms, mainly in the dissolved and in the solid state (adsorbed onto surfaces of clays, element oxides, organic material, co-precipitated with sediment phases and incorporated into organic matter). The highest proportion is usually in 
the solid phase. How an element is bound in sediment determines the biologically active fraction and its fate and cycling.

Understanding the processes affecting trace metals concentration and their fate in sediments is important in gauging appropriate designs for sampling and monitoring programs and planning for appropriate remediation options (Williamson and Wilcock 1994).

\subsubsection{Heavy Metals Input into Sediments}

Metal enrichment in the sediments is usually located close to past and present sources of pollution ( Luoma 2000). Simply, concentrations drop with distance away from the source of input as determined by the physical processes that dilute and redistribute the particles with which metals associate as in the case of dilution with less contaminated sediments (Fergusson 1990; Luoma 2000). However, the rate of decline in concentration with distance from sources of pollution is extremely variable (Williamson and Wilcock 1994). Metal concentration in sediments are not only determined by metal inputs but also effected by other complex factors such like sediment characteristics and reactions at particle surfaces that influence the quantity of metal adsorbed, and reduction/oxidation reactions (Luoma 2000).

\subsubsection{Sediment Texture}

Metal concentrations in marine and estuarine sediments are determined not only by metal inputs but also by sediment characteristics. Grain size distribution has been recognized to affect trace metal concentrations in estuarine and marine 
sediments (Luoma 2000). Generally, trace metals are mainly concentrated in the silt/clay sediment fraction; consisting of particles with a grain size $<0.063 \mathrm{~mm}$. The enrichment of the silt/clay fraction by anthropogenic trace metals is due to the large specific area of this fraction and to the strong adsorptive properties of clay minerals (Krumgalz, et al. 1992).

Fine grained sediment of this particular fraction has a high absorption potential because the sediment has a large surface area to ratio, and contain large amounts of interstitial water (Loomb 2001). The feature of fine grained sediment that is of significance regarding the trace metals is their ability to absorb metal ions by their outer sheath of hydroxyl groups (Fergusson 1990). The surface of this sediment size may be also negatively charged which is crucial in providing potential absorption sites for metal ions (Fergusson 1990). Fine grained minerals also have a higher surface area to volume ratio and can absorb material into their lattice framework (Loomb 2001).

\subsubsection{Sediment Composition}

One of the most important sediment characteristics is the concentration of sediment components. The concentrations of the important metal-reactive components of sediments can vary among estuarine and marine environments (Luoma 2000) and are found to increase as sediment textures become finer. The sediment components contain many phases that strongly adsorb metals such as amorphous iron oxides, manganese oxides, and polar organic matter (Williamson, et al. 2003). 
The nature of Fe oxides, organic materials, or Mn oxides will determine site densities for sediment components; and the relative concentrations of $\mathrm{Fe}, \mathrm{Mn}$ and organic materials will determine aggregate differences in binding site density or binding intensity (Luoma 2000). Amorphous iron hydrous oxide has a large surface area per unit weight. It is abundant and it may be an important medium for trace metal adsorption. Concentrations do not change greatly with depth or redox conditions, though are strongly dependent on sediment texture (Williamson and Wilcock 1994). Amorphous manganese oxide concentration is lower than iron oxides, though its rapid cycling between reduced and oxidized forms, and between sediments and water mean that it is important in trace metal mobilization from sediments (Williamson and Wilcock 1994).

Generally organic matter content of sediments increase as the sediment texture becomes finer (Denton, et al. 2001). The presence of organic matter can potentially increase metal concentrations in sediment by adsorption of metals from surrounding environment onto organic material (Loomb 2001). Also dead organisms in sediments may carry the heavy metals with them, either taken in by the organism while alive or sorbed on to the animal before or after death (Fergusson 1990) and this contribute directly to the metal levels in the sediments. Organic compounds containing metal ions may also be sorbed onto Fe-Mn oxides. Organic materials can affect metal species solubilization by complexing the metal ions, but they can also take metal ions out from the solution and contribute to the sediments. Decomposition of organic material produces organic ligands that may extract metals from the sediments which can effectively mobilize metals by increasing their concentration in the water. Interestingly, the Irving-Williams 
series of increasing stability of metal complexes is the same order as increasing mobilization (Fergusson 1990);

$\mathrm{Mn}<\mathrm{Fe}<\mathrm{Co}<\mathrm{Ni}<\mathrm{Cu}<\mathrm{Zn}$

\subsubsection{Redox Reactions}

In the surface sediments, organic matter is decomposed by organisms in the presence of oxygen. In finer sediments such as clay, with the exception of coarse sediments and other high-energy areas where there is rapid advection of oxygenated water, this decomposition uses up oxygen in the sediment quickly. The decomposition occurs faster than the rate of diffusion of oxygen into the sediments and, as a result, most sediment is anaerobic just below the surface (Williamson, et al. 2003). The decomposition of organic matter proceeds under anoxic conditions using alternative electron acceptors to oxygen, such as nitrate, manganese and iron oxides, and sulfate to oxidize organic carbon. This oxidation, together with the resulting anoxic conditions, produces large changes to the form of iron, manganese and sulfur, which are important in binding trace metals in sediment and releasing them to the overlaying water (Williamson and Wilcock 1994).

\subsubsection{Adsorption/Desorption}

The release of metals from toxic sediments can happen as the salinities increase or reduction/oxidation condition changes due to the high ionic strength of seawater 
and potential competition for binding sites with $\mathrm{Ca}$ and $\mathrm{Mg}$ (Luoma 2000). The flux of oxygen from the water to the sediments controlled the reaction at the interface; hence the depletion of oxygen consequently limits the release of the metals into the water. The extent of losing the metals from toxic sediments can be reduced by re-adsorption to precipitating Fe and Mn oxides.

\subsubsection{Physical Transport}

Sediment type and dynamics are known to affect contaminant concentration and fate. In coastal environments with low hydrodynamic energy, fine particulates tend to be trapped, while in areas where hydrodynamic energy is high, fine particulates are moved on. There are three main zones that can be distinguished based on three types of processes (Williamson and Wilcock 1994; Williamson, et al. 2003).

i) areas of accumulation (deposition). This is where fine materials are continuously being deposited. Wave and current energies are very low in this area; ii) areas of transportation. This is where fine materials are deposited discontinuously, and

iii) areas of erosion. This is where there is little deposition of fine materials. Wave and/or current energies are high in this area.

For most metals, the intermediate fate is the deposition area where the finest sediments generally accumulate (Luoma 2000). These areas tend to be sheltered estuaries and embayment, and deeper water offshore. The ultimate fate of heavy metals is burial given that metals do not break down. When buried, heavy metals 
become immobilized as insoluble sulfide precipitates due to the decomposition of organic material (Williamson, et al. 2003).

\subsubsection{Bioturbation}

A lot of studies have suggested that bioturbation strongly affects the physical, chemical and biological properties of sediments. Biological mixing is more important in muddy sediments than sandy sediments, where strong physical processes occur. There are two groups of animals based on the magnitude of sediment disturbance;

i) large individual predators, such as rays and crabs, may shift large amount of sediment when searching for food, and

ii) smaller animals such as worms and gastropods. The latter burrow and ingest sediment, shift only small amounts of sediments, but their high population densities make them important in sediment turnover (Williamson and Wilcock 1994).

Bioturbation has a major impact on the chemistry of muddy sediments. Oxygen penetration in unbioturbated sediments is highly restricted, and the redox boundary occurs a few millimeters below the surface. Marine organisms, such as polychaetes and crabs, create extensive honeycombs in mud flats up to $60 \mathrm{~cm}$ in depths allowing oxygen to be transported deep within the sediments via burrows (Williamson and Wilcock 1994). These honeycombs, in turn, provide low tide irrigation of burrow water, which maintains oxic conditions when tidal flats are submerged. In this way, the sediment becomes a honeycomb of oxic and anoxic environments. 
Burrowing organisms also can alter the levels and the speciation of heavy metals in sediments by affecting the sediment stratigraphy to become blurred, particle size altered, pore spaces and $\mathrm{pH}$ changed. Consequently, metal concentrations do not appear to change rapidly with depth. The organisms may also bio-accumulate heavy metals and remove them from the sediment profile hence decreasing the metal concentrations in the sediments (Fergusson 1990).

\section{4 potential Heavy metals contamination associated with impounded water systems:}

Impounded water bodies are those isolated partially or totally from the main water system. They may be fresh water as in dams or sea water as in estuaries or basins. Impoundment may result from geologic processes (e.g. earthquake) or human intervention (e.g. urbanization). Early in the 1900s, extensive urbanization in different parts of the world was associated with manipulation of water bodies, so as to "fit" them within the proposed structure plan for a particular region. Indeed, it is the architect's dream to fit his buildings with a beautiful blue water body. Before long, however, it was recognized that this would not be without a price. Environmental costs ranged from degradation of the entire ecosystem to severe outbreaks of mosquitoes. Local examples of impounded water bodies lie along Doha bay, and there are Aluasil and the Peral Qatar projects. Many environmental effects can be easily predicated along these shores with time in comparison to other not so recent built bays such as Orakei Basin, Auckland, New Zealand. Figures 2 shows the effect of black mud formation while figure 3 meant to show the similarities in design between Orakei Basin and the pearl Qatar. 


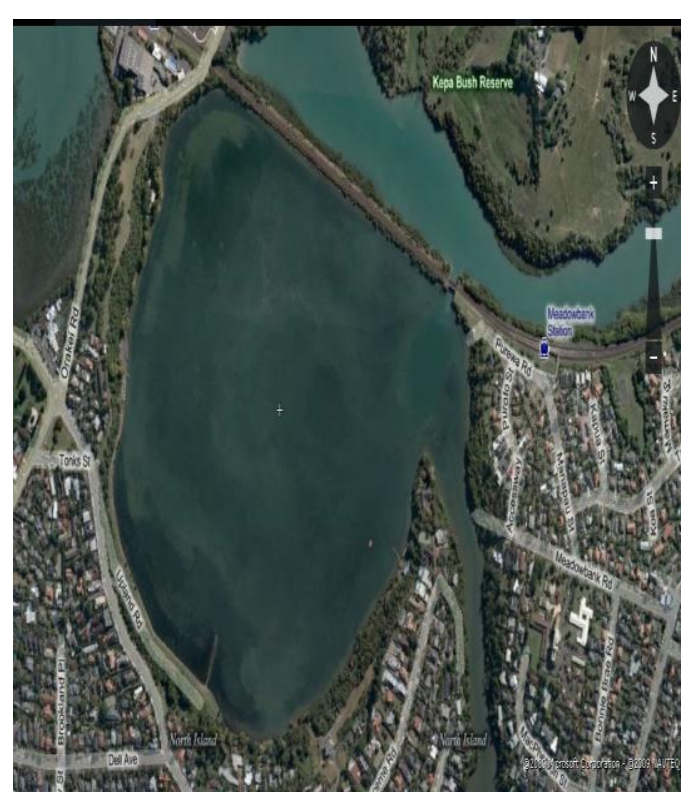

Figure 2: Orakei Basin, Auckland, New Zealand. Source: Google Earth, November 2009

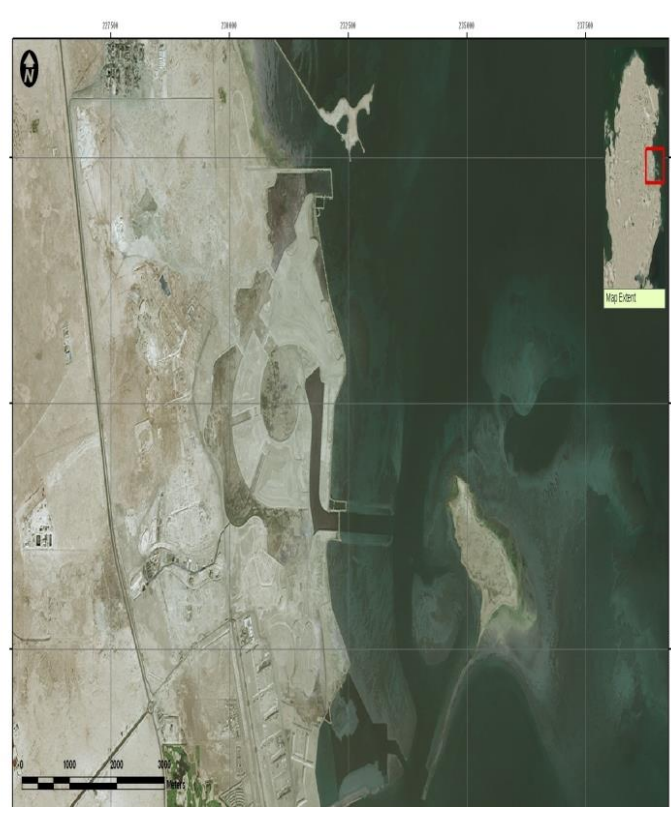

Figure 3: The Pearl Qatar project

Source: Google Earth, April 2012

Some of these environmental effects may include the following (Binning and Baird 2001):

- Water stratification: oxygen content of the lower part of the impounded water body would be consumed by the oxidation of the organic matter while the upper layer would have higher oxygen due to its contact with the atmosphere causing the lower layer to become anoxic (poisonous) gradually.

- Biochemical Oxygen Demand (BOD): water would have high BOD due to consumption of the high organic content of the water that might leads to a decrease in biodiversity and therefore to deterioration of the quality of the water.

- Siltation: the release of mud and silt-sized sediment to the water which increases the ability of heavy metals to bind to the sediment surface; hence 
increasing heavy metal pollution. Also, algal materials would stick to these materials and deposit them down forming muddy substratum which can pose a great threat to organisms that live on solid ground like corals because mud blocks the gills of breathing organisms like fish and block pores of corals.

- Change of pH: as more organic contents increase the water becomes more acidic

- Salinity increases: due to higher evaporation and less water movement

- Temperature variation: the higher the temperature the more reactive the analyte in question. Temperature is normally directly related to the dissolution rate of metals. This rule suggests that metals are more soluble at higher temperatures and more available in water column, on the other hand, at lower temperatures the metals precipitate out in the sediments (Fergusson 1990; Luoma 2000).

- Nutrient level increase: also as more P (phosphorous) and N (Nitrogen) would be added to the water body with minimum recharging

- Eutrophication: Resulting in active growth of algal materials due to the high content of nutrients and the minimum disturbance of water(Williamson, et al. 2003).

- Growth of anaerobic bacteria: which is associated with the formation of many toxic compounds such as Pyrite $\mathrm{FeS}_{2}$ that is responsible for the black color mud around Orakei Basin(Luoma 2000). Black mud region is a very hostile environment that affects the existence of many organisms. 
Many of the mentioned effects contribute on the increase of heavy metal upload (Luoma 2000). Figure 4 illustrates the massive formation of black mud in Orakei Basin.

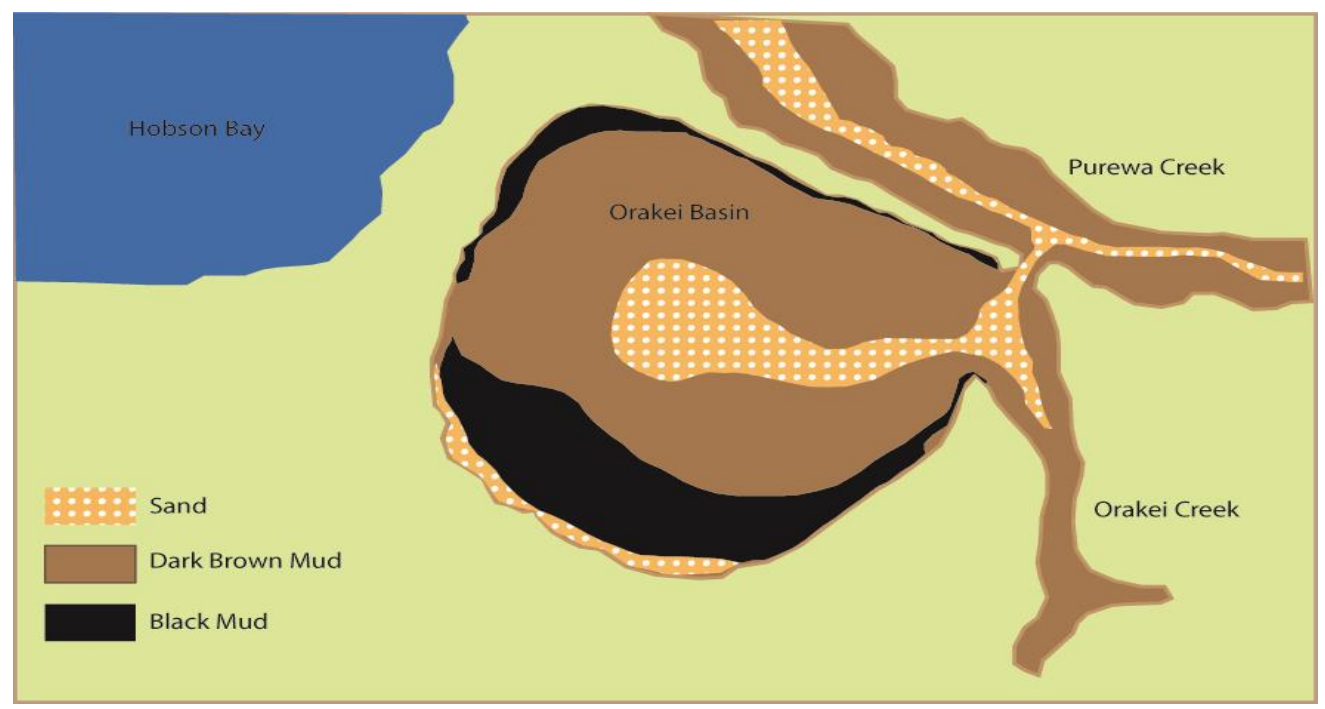

Figure 4: a diagram of Orakei basin illustrating the massive formation of black mud. Source: http://www.aucklandcity.govt.nz/council/services/orakeibasin/bylawchange.asp

\subsection{Assessment of Contaminated Sediments}

This part is conducted by the ESC as it is considered as an important part of the whole project. The environmental fate of contaminants must be understood in order to predict potential impacts on human health and ecosystems. Extensive experience is required for understanding how contaminants enter water bodies, the geochemical processes that govern their bioavailability, and how they are transformed by biological, geological and chemical processes over time Scientists design and oversee sampling and analysis programs to identify whether and to what extent various key effects may be occurring and the source of environmental risks. These data are used in a risk management setting in concert with industry and regulators to determine whether remediation is appropriate and identify the 
optimal courses of action.

Field studies may also include an important environmental forensics component, which can help allocate liability among various sources. Risk posed by sedimentassociated chemicals to aquatic organisms is best understood through an evaluation of sediment quality, known as the Sediment Quality Triad: sediment chemistry, toxicity, and benthic community. Measurements of these three areas are integrated to reach conclusions based on the degree of risk indicated by each measurement and the confidence in each measurement. Exponent ecologists and toxicologists have extensive experience in applying the Sediment Quality Triad approach to sediments containing metals, polychlorinated biphenyls (PCBs), polycyclic aromatic hydrocarbons (PAHs), and pesticides. Scientists working in this field should have specific expertise in cost-effective study design, including selecting appropriate test methods, interpreting results of Sediment Quality Triad studies, and developing technically defensible cleanup goals to support remedial decisions. Assessing the toxicity of the complex mixture of contaminants that can be present in sediment can be a challenging undertaking. For example, individual compounds in oil vary in potency and modes of toxic action, and the influence of weathering changes the composition and toxicity of the mixture. Technical approaches to understand and predict the toxicity of individual sediment contaminants are required and it should be developed site-specific sediment quality guidelines and cleanup levels (Ansari, et al. 2004). 


\section{Chapter 3. METHODOLOGY}

\subsection{Sampling Method}

All Samples are collected by ESC sampling team. They were taken by a diver using Teflon beaker and then were kept in glass jars. All glass jars were labeled and pretreated to suit this experiment. The obtained samples meet the requirements of the sampling program and handle so that they do not deteriorate or become contaminated before it is analyzed, hence samples were transformed to a freezer at temperature of $-4 \mathrm{C}^{\circ}$ (set by $\mathrm{ESC}$ ) for preservation required until analysis.

\subsection{Sample Preparation}

Sample preparation is the first step in our project workflow, and sets the foundation for the quality of the results. However, the main principle of the sample preparation is to ensure that the samples are in the best condition required for the selected analysis. The samples preparation includes the following steps in the project:

1. Drying using freeze dryer ( Stoppering Tray Dryer, LABCONCO)

2. Grinding (Retsch model PM400)

3. Digestion by a mixture of strong acids using Hot Block system (Environmental Express).

4. Cooling and dilution. 


\subsection{Sample Analysis}

All samples were fully analyzed using Inductively Coupled Plasma-Optical Emission Spectrometry (ICP-OES), Perkin-Elmer, Optima 5300 DV located at ESC. The representative marine sediment samples are accurately weighed and treated with acids using hot block system in order to destroy the organic matter in the samples; thus the total recoverable elements concentration will then be determined. After cooling, the sample is made up to the volume with deionized water and filtered if turbid. The sample solution is aspirated through nebulizer and the resulting aerosol is transported to the plasma torch where excitation occurs. Element specific emission spectra are produced by radio-frequency inductively coupled plasma. The spectra are dispersed by a grating spectrometer, and intensities of the line spectra are monitored at specific wavelengths by a charged coupled detector (Channeltron electron multiplier). A fitted background correction is used to correct the blank signal and matrix effect. The standard operational procedure number is SOP-ESC-ICP-01 which was developed using USEPA 3051A for marine sediments digestion and EPA6010b for sample analysis. See Appendix C for detailed experimental procedures. In addition, the effect of grinding time was considered in the design of this experiment to study the consequence of grain size on the metals uptake.

\subsection{Quality Control Measures}

The ICP lab at the ESC is an accredited lab with the ISO17025 and it adapted many quality control criteria such as: 
- Field blank

- Method blank

- Reagent blank

- Initial calibration verification (ICV)

- Continuous calibration verification (CCV)

- Matrix Spike

- Certified reference material (CRM)

- Multi elements calibration

- Sample replication

About $10 \%$ of total number of samples were subjected to quality control measurements. Moreover, the data which are obtained below the sensitivity of the method of analysis and instrument used were reported as below the limit of quantitation (LOQ). Limit of Quantitation (LOQ) is defined as the lowest amount of analyte in a sample which can be quantitatively determined with suitable precision and accuracy of an individual analytical procedure. It is a parameter of quantitative assays for low levels of compounds in sample matrices, and is used particularly for the determination of impurities and/or degradation products.

Tables 1 to 6 in the Appendix B show the quality control criteria measured during the study.

\subsection{Statistical Analysis}

Data processing was included the followings:

- Upper acceptable limit 
- Lower acceptable limit

Upper and lower acceptable limits are confidence limits for the mean- an interval estimate for the mean. Interval estimates are often desirable because the estimate of the mean varies from sample to sample. Instead of a single estimate for the mean, a confidence interval generates a lower and upper limit for the mean. The interval estimate gives an indication of how much uncertainty there is in our estimate of the true mean. The narrower the interval, the more precise is our estimate.

- Repeatability

Repeatability is the variation in measurements taken by a single person or instrument on the same item and under the same conditions. It can be expressed as standard deviation $(s)$, variance $\left(s^{2}\right)$, probability distribution function, etc for a suitable number of measurements made under repeatability conditions ((Bland, 2001).

\section{- Reproducibility}

Reproducibility is the precision estimate obtained when a series of measurements are made under more variable conditions, i.e. the same method on identical test items used by different operators with different equipment in different facilities at different times. It can be expressed as standard deviation (s), variance, probability distribution factor, etc. At the ICP laboratory of ESC reproducibility is measured 
every six months by performing a Proficiency Testing check (PT) with another accredited laboratory

\section{- Recovery\%}

Percentage of spike recovery is calculated using a mathematical equation as a measure of precision (Bland, 2001).

An acceptable recovery $\%$ at ESC is $>90 \%$.

For the purpose of comparison, the study used a statistical analysis tool to establish and evaluate significant differences on the results obtained for each metal. Multivariate and Repeated Measures Analysis of Variance (ANOVA) are incorporated to delineate the differences among the 10 transects and between the study duration. Since all groups of data are expected to differ from each other to some degree, the extent to which groups differ can tell us whether they are intrinsically similar and can thus be assumed to be the same or whether they are effectively different. The primary tool used to make this determination is ANOVA. It distinguishes between groups of mean values by comparing variance. These variances are partitioned in ANOVA so that separate measures are provided for variation between the groups and within each group.

Analysis of variance (ANOVA) is a technique for analyzing the way in which the mean of a variable is affected by different types and combinations of factors. It gives a single overall test of whether there are differences between groups or treatments. In this study, differences between groups and within the groups were 
analyzed. In order to identify the differences between treatments it is necessary to look more closely at the meaning of a $P$ value.

When interpreting a $P$ value, it can be concluded that there is a significant difference between groups if the $P$ value is small enough, and less than 0.05 (5\%) is a commonly used cutoff value. In this case $5 \%$ is the significance level, or the probability of a type I error. This is the chance of incorrectly rejecting the null hypothesis (i.e. incorrectly concluding that an observed difference did not occur just by chance) (Bland, 2001), or more simply the chance of wrongly concluding that there is a difference between two groups when in reality there's no such difference. Post Hoc test is performed to know which means of all the groups tested for ANOVA which rejected the null hypothesis. Tukey's Honestly Significant Difference is used as post hoc test as this is most sensitive robust analysis to identify the significant differences between and within the group being tested. 


\section{Chapter 4. RESULTS AND DISCUSSION}

The following section gives the detailed investigation on the metal analyses as an environmental indicator made to survey the sediment samples obtained from the coastal area north of Doha, north of the Pearl Qatar project and south of $\mathrm{Al}$ Safeliya on the eastern coast of Qatar. It is important to look for ecological indicators to assess the condition of the environment. They are valuable in providing early warning signals, diagnose, and formulate solutions on the causes of any environmental problem. There are several factors that influence the magnitude of the key indicators; it must be ideally selected to represent vital information about the structure, function and composition of the ecological system.

The study determined the concentrations of 25 metals in sediment samples and aimed at investigating the factors that influenced its levels. There were a total of 50 samples analyzed from the 10 transects consisting of 5 stations within the study area (Figure 1). There were two study durations made which the first phase was carried out on May 2012 while the second phase was on December 2012. These transects will be evaluated for spatial variation while the 2 phases will be for temporal variation. To establish comparison and variability over the course of the study, a statistical analysis was employed using Analysis of Variance (ANOVA) and a post hoc Tukey's Honestly Significant Difference Test to further delineate the overall differences between transects and overtime. The data is represented by a Box and Whisker plot to show the spread of the values observed in each transect in a form of minimum, maximum, 3rd quartile, 1st quartile, the median and the 
outlier. The central line indicated central tendency or the median; the large box indicated the variability around the central tendency. The standard error or the 3rd quartile and 1st quartile; and the whiskers around the box indicated the minimum and maximum range in the data. Moreover, the values obtained were compared with the international guidelines with its designated contaminant criteria.

Tables 1\&2 in Appendix A show the consolidated results of the different metals analyzed from the two phases of the study. The metals $\mathrm{Ag}, \mathrm{Ca}, \mathrm{Na}, \mathrm{Se}$, and $\mathrm{Sr}$ were not included in the table as the results for $\mathrm{Ag}$, $\mathrm{Se}$, and $\mathrm{Sr}$ for all samples recorded lower than limit of quantitation while $\mathrm{Ca}$ and $\mathrm{Na}$ results were erroneous and best analyzed in ionic forms, thus need a different preparation strategy than what ESC follows in their SOP.

\subsection{Spatial Variation of the Metals Concentration}

Understanding the spatial distribution of data is essential in elucidating the dispersion of the contaminant within a geographic location. It provides visualization of the spatial pattern of the immensity of the pollution through the generation of a contour map using Geographic Information System (GIS) at ESC. The emphasis of the spatial analysis is to measure properties, identify relationships and differences taking into account the spatial localization. The present study had incorporated spatial analysis on different transects analyzed on different duration within the study area. It was found that significant differences were observed to most metals around the study area except $\mathrm{Ba}-\mathrm{Dec} 2012\left(\mathrm{~F}_{(9,40)}\right.$ $=1.054 ; \mathrm{p}>0.05) ; \mathrm{Cd}-$ May $2012\left(\mathrm{~F}_{(9,40)}=0.656 ; \mathrm{p}>0.05\right) ; \mathrm{K}-$ Dec 2012 $\left(\mathrm{F}_{(9,40)}=1.951 ; \mathrm{p}>0.05\right) ; \mathrm{Li}-\operatorname{Dec} 2012\left(\mathrm{~F}_{(9,40)}=1.160 ; \mathrm{p}>0.05\right) ; \mathrm{Mg}-$ May 
$2012\left(\mathrm{~F}_{(9,40)}=1.729 ; \mathrm{p}>0.05\right) ; \mathrm{Sb}-$ May $2012\left(\mathrm{~F}_{(9,40)}=1.558 ; \mathrm{p}>0.05\right) ; \mathrm{Hg}-$ Dec $2012\left(\mathrm{~F}_{(9,40)}=1.462 ; \mathrm{p}>0.05\right)$. The transects $\mathrm{E}-\mathrm{J}$ has significantly higher metal concentration as within these locations it was evident that there are a lot of anthropological activities. On-going construction activities, presence of marinas, the 4 surface water discharge points along the coastline and the fact that the area is an enclosed location with an impounded water system are the contributory factors to the measured level.

Figure 5and 6 show the maps of the distribution of Zn metal surrounding the study area during the two sampling durations. $\mathrm{Zn}$ is commonly used for roof constructions, gutters, drainpipes, roof flashings and coverings. $\mathrm{Cu}$ and $\mathrm{Pb}$ has similar applications. According to Wood 1974, $\mathrm{Zn}, \mathrm{Cu}$ and $\mathrm{Pb}$ are three of the most toxic and relatively accessible metal which when exposed to the atmosphere and or washed to the open waters will ultimately contribute to the pollution loading within the area. In the present study, these metals differ significantly in their dispersion within the study area (Tukey HSD, $\mathrm{p}<0.05$ ). Zn and $\mathrm{Cu}$ metals have an average concentration of $6.49 \pm 2.72 \mathrm{ppm}$ and $2.70 \pm 1.66 \mathrm{ppm}$ respectively while $\mathrm{Pb}$ obtained concentrations below the limit of quantitation.

$\mathrm{V}$, and $\mathrm{Ni}$ are known to be the primary constituents in crude oil (Alloway 1995). The concentrations obtained for $\mathrm{V}$ and $\mathrm{Ni}$ in both sampling duration were found to be significantly different. (Tukey HSD, $\mathrm{p}<0.05$ ) Higher concentrations were observed in southern part Doha bay. This area is where the marina is located. The average concentration for $\mathrm{V}$ is $6.21 \pm 3.38 \mathrm{ppm}$ while for $\mathrm{Ni}$ is $3.97 \pm 2.26 \mathrm{ppm}$. 
Figures 7 and 8 show the maps of the distribution of $\mathrm{V}$ metal surrounding the study area during the two sampling durations

Some metal concentrations were observed to be below the limit of quantitation (LOQ) of the instrument's sensitivity. As, $\mathrm{Be}, \mathrm{Ca}, \mathrm{Co}, \mathrm{Mo}, \mathrm{Pb}, \mathrm{Se}$ and $\mathrm{Sr}$ were recorded < LOQ to most stations during the May 2012 sampling while $\mathrm{Be}, \mathrm{Ca}, \mathrm{Co}$, $\mathrm{Pb}, \mathrm{Se}$, and $\mathrm{Sr}$, for December 2012. 


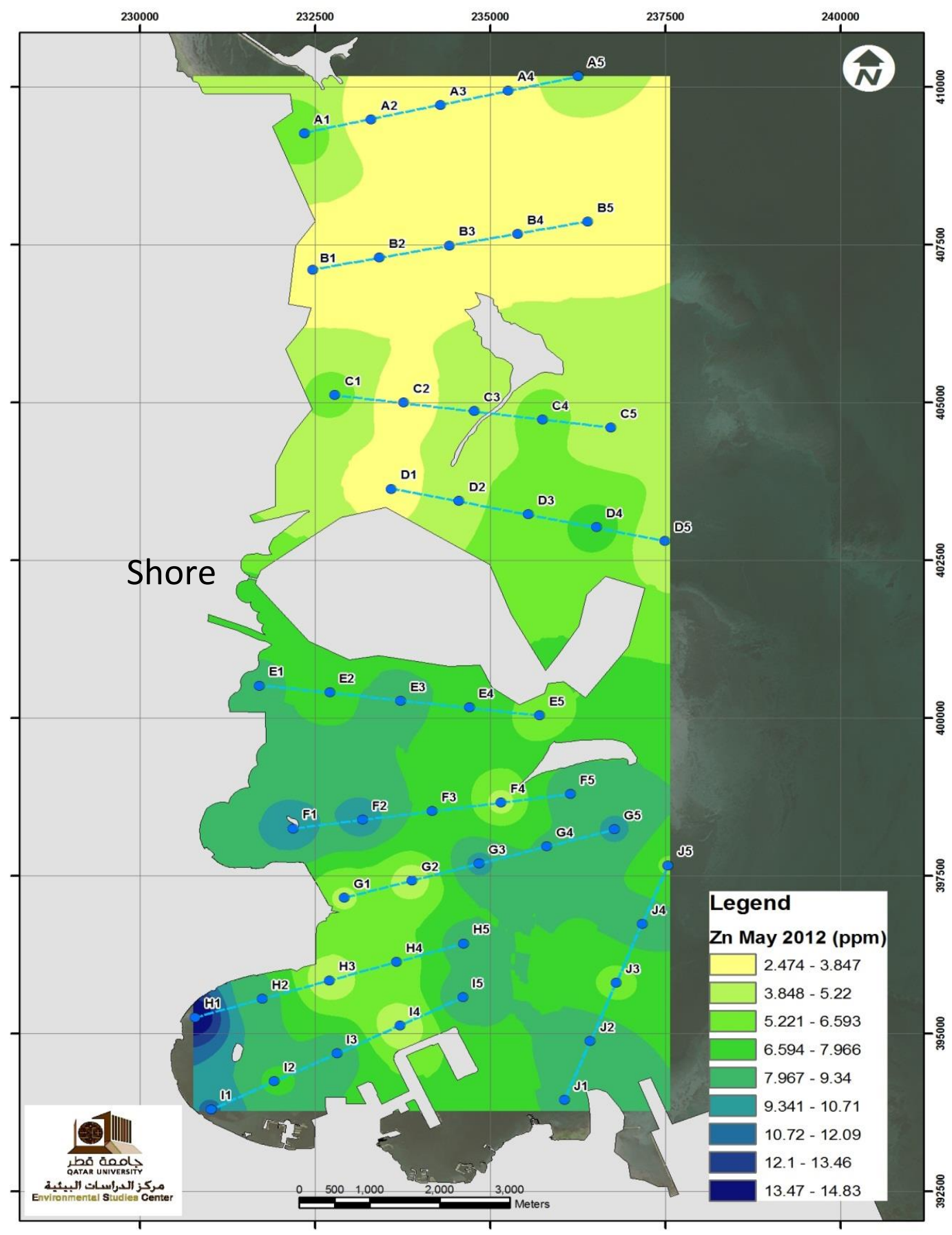

Figure 5: Contour Map showing the distribution of Zinc metal around Doha Bay during May 2012. 


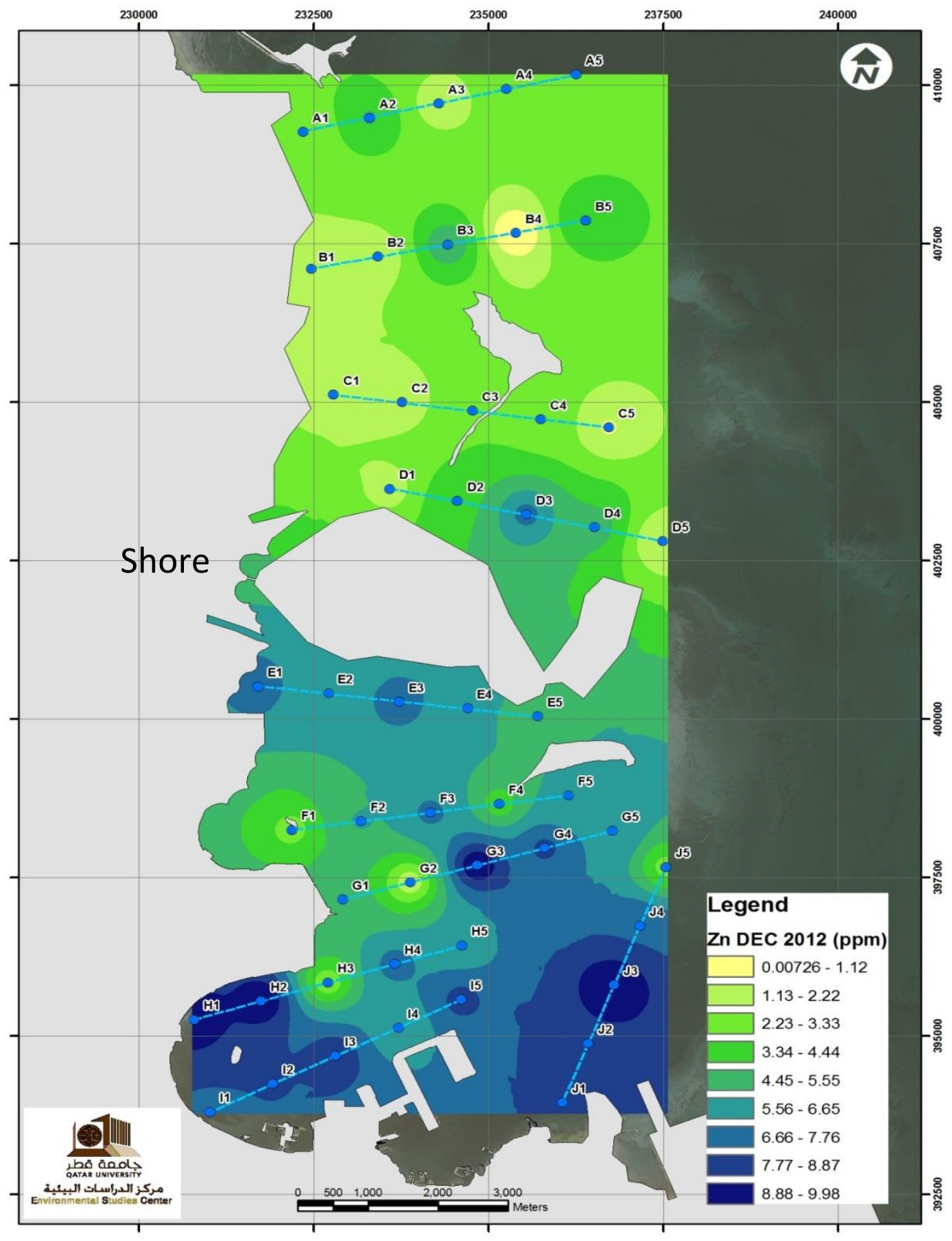

Figure 6: Contour Map showing the distribution of Zinc metal around Doha Bay during December 2012. 


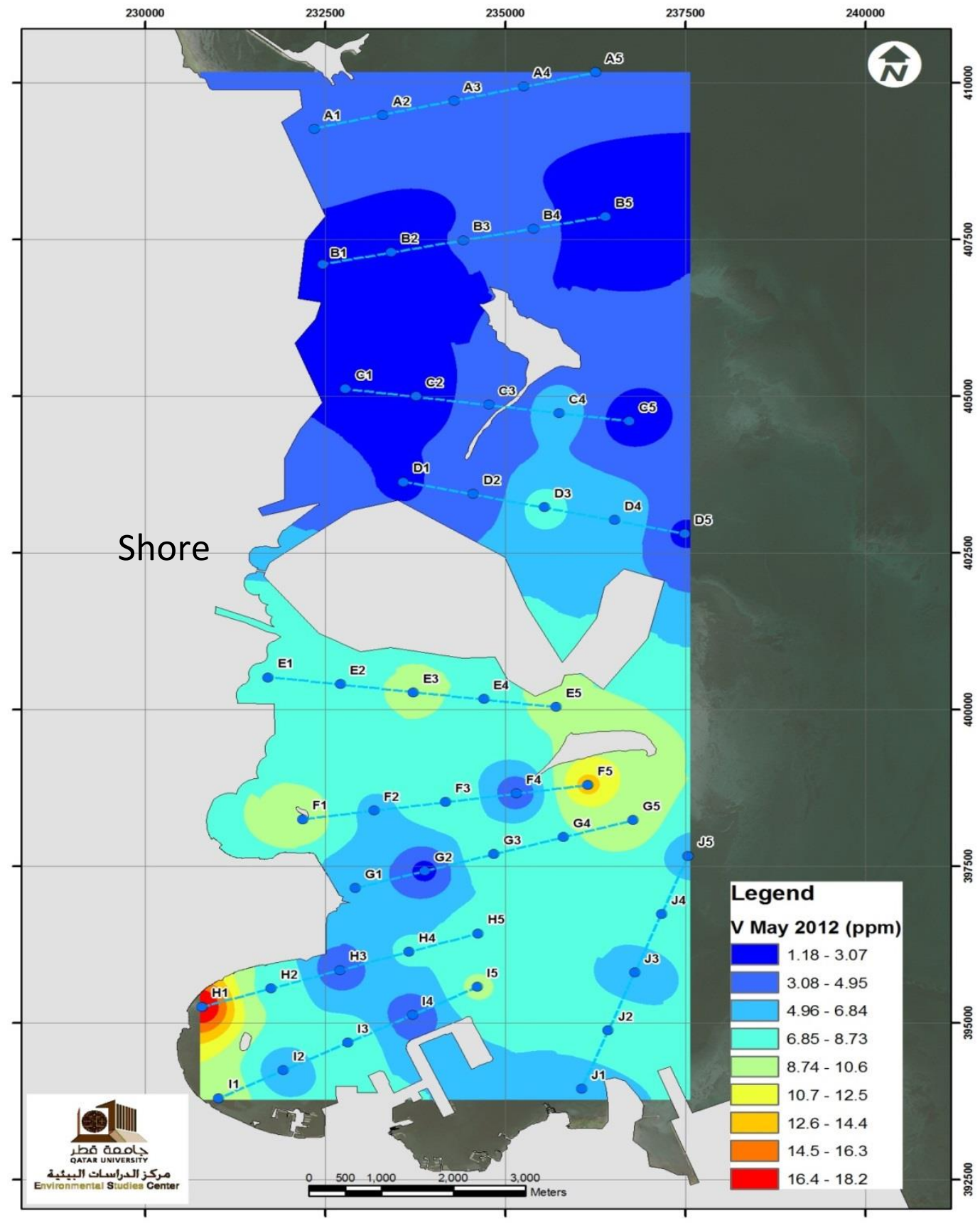

Figure 7: Contour Map showing the distribution of Vanadium metal around Doha Bay during May 2012. 


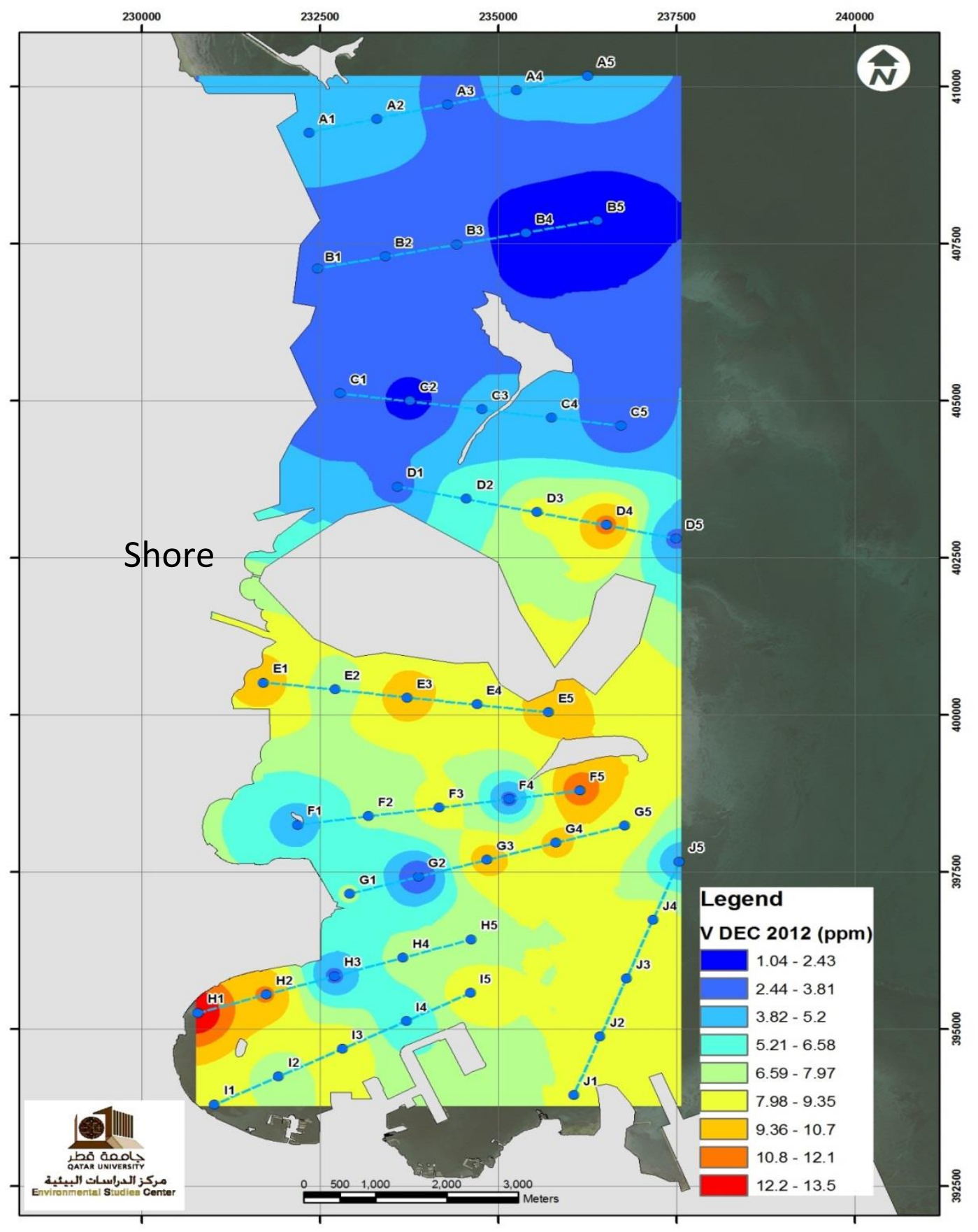

Figure8: Contour Map showing the distribution of Vanadium metal around Doha Bay during December 2012. 


\subsection{Seasonal Variation of the Metals Concentration}

Metals are classified into three criteria according to environmental impact. These classifications include their reactivity and availability to ecological system. Trace metals normally occur at very low levels in the environment. They exert a variable range of toxicity and effect, while some metals such as $\mathrm{Mn}, \mathrm{Fe}, \mathrm{Cu}$, and $\mathrm{Zn}$ are essential metal micronutrients, others such as $\mathrm{Hg} ; \mathrm{Cd}$ and $\mathrm{Pb}$ are not required even in small amount by any organism (Fergusson 1990; Luoma 2000). These metals are stable and exist as persistent environmental contaminants which impose havoc to the organisms and the environment. They are known as heavy metals which are very toxic and tend to accumulate in the soils and sediments (Williamson, et al. 2003). Overtime, these metals accumulate within the sediments and the latter become an important reservoir of metal concentrations which provide input record of the pollution loading within a system.

The present study obtained results from two sampling duration. Overtime, the metal concentration was found to significantly differ from each station within the study area. It was observed that higher concentrations were observed during the sampling done on December 2012 compared with May 2012. Below shows the summary of the relationship of the metal concentration analyzed from the different transects during the two sampling duration. The relationship was assessed using Repeated Measures ANOVA and further delineated using post hoc test. 
- $\mathrm{Al}, \mathrm{Ba}, \mathrm{Cd}, \mathrm{Cr}, \mathrm{Cu}, \mathrm{K}, \mathrm{Ni}, \mathrm{Sb}, \mathrm{Zn}$, and $\mathrm{Hg}$ metals show significant differences over the two period of the study (ANOVA, $\mathrm{p}<0.05$ ). Higher concentrations were observed during the December 2012 sampling. Temperature variation within a season is one of the factors that affect metal concentration. According to Fergusson, 1990 and Luoma, 2000, the metal concentration in sediment is temperature dependent where the marine sediments are suspected to have less metal concentration during the summer season and higher concentration on water column due to vertical mixing. Qatar has an arid climate with May as the beginning of summer and December as the winter season which is evident with obtained results. In addition to this factor that may influence the metal concentration measured during the study, there is an increased constructions and modifications within the area which contribute to the results. In fact an ongoing activities such as hotel and building constructions i.e. Pearl Qatar, Lusail Development. Project, Karata project, West Lagoon, Doha Harbor. Figures 9 to 17 show the comparison of the two sampling duration and degree of distribution of the metals concentrations around the study area.

- $\mathrm{Fe}, \mathrm{Li}, \mathrm{Mg}, \mathrm{Mn}$ and $\mathrm{V}$ metals show no significant difference on the concentration over the two period of the study. (ANOVA, p >0.05) However, among the transects, significant differences were observed having higher concentration within the location with most activities. 


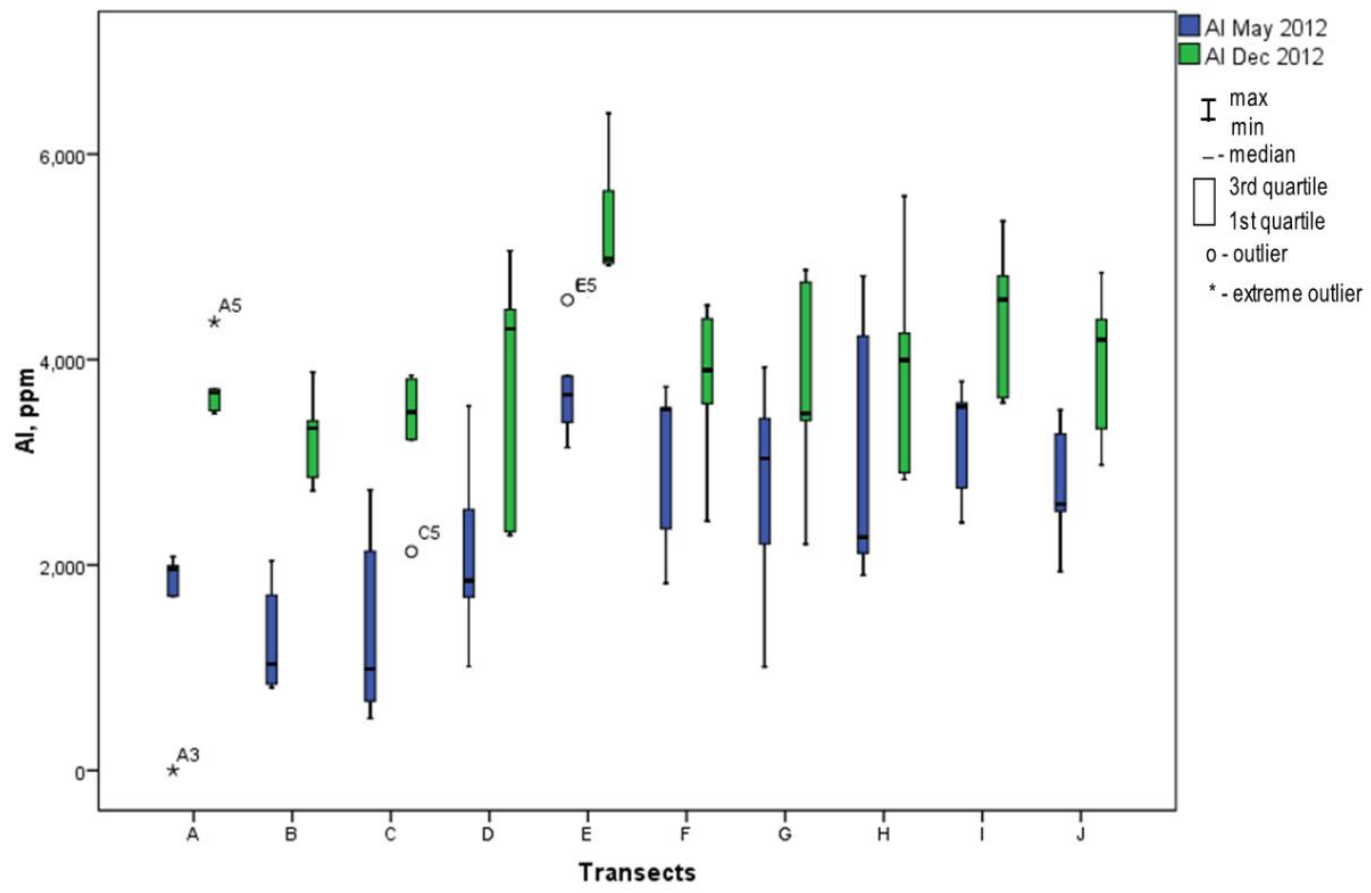

Figure 9: Aluminum concentration recorded from the sediment samples collected around Doha Bay during May and December 2012 sampling.

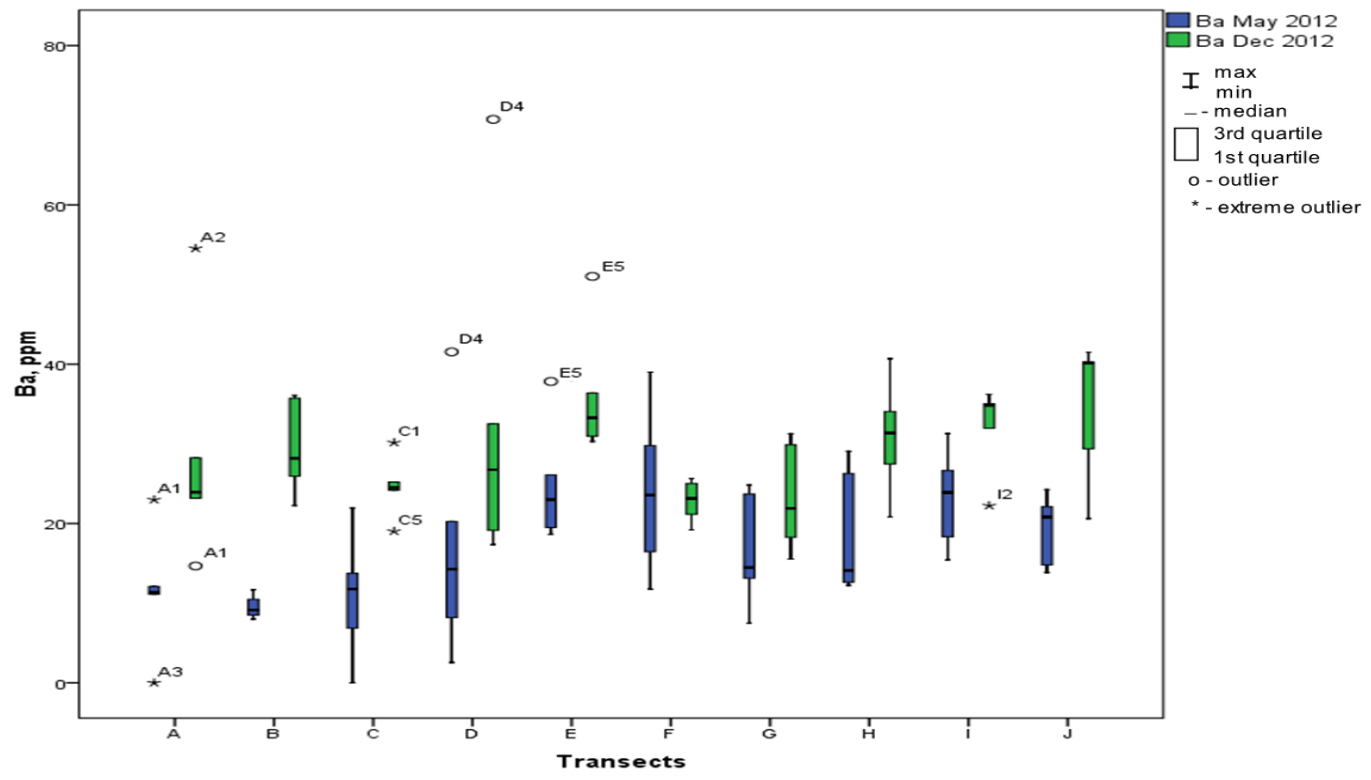

Figure 10 : Barium concentration recorded from the sediment samples collected around Doha Bay during May and December 2012 sampling. 


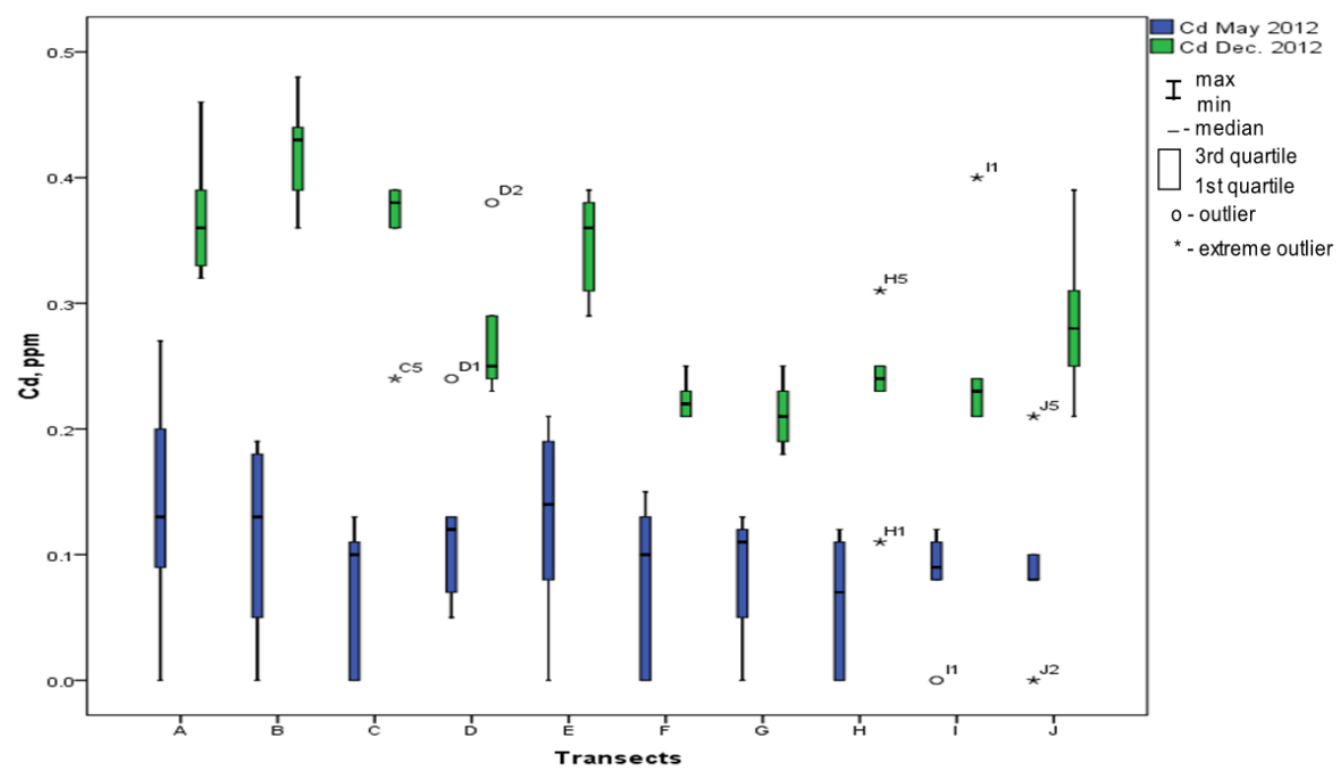

Figure 11: Cadmium concentration recorded from the sediment samples collected around Doha Bay during May and December 2012 sampling.

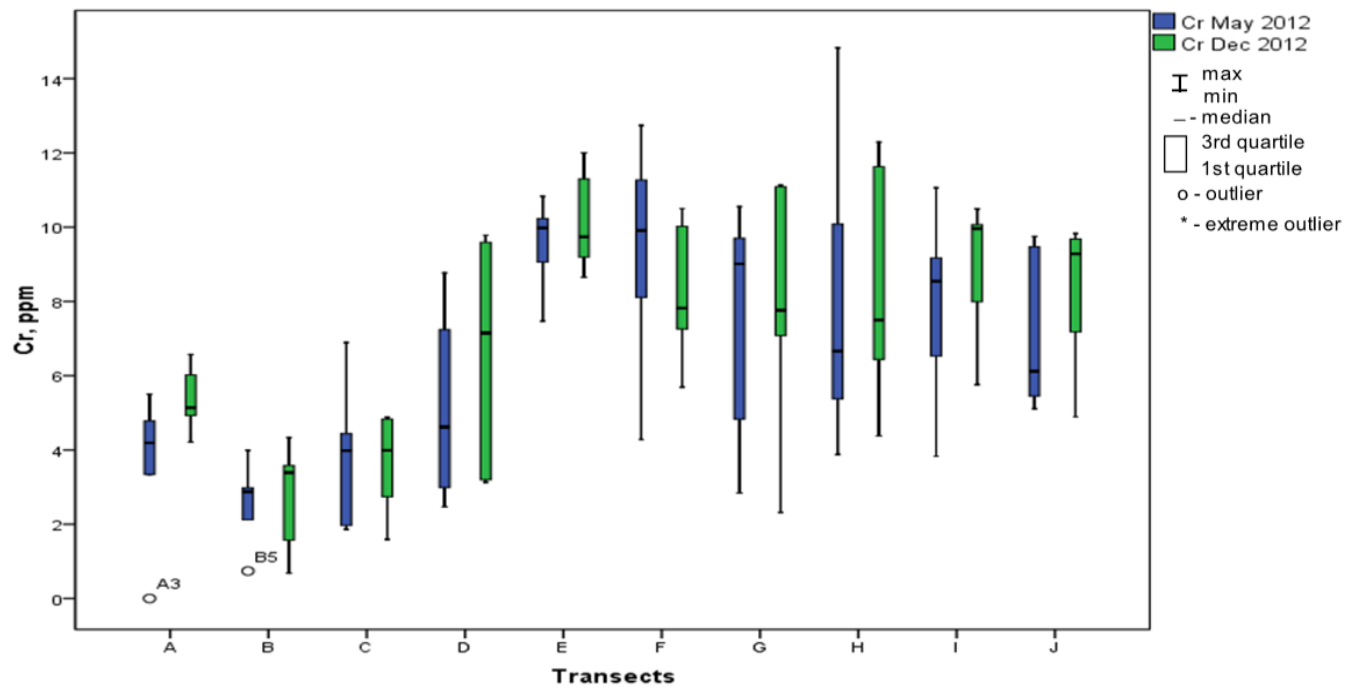

Figure 12: Chromium concentration recorded from the sediment samples collected around Doha Bay during May and December 2012 sampling. 


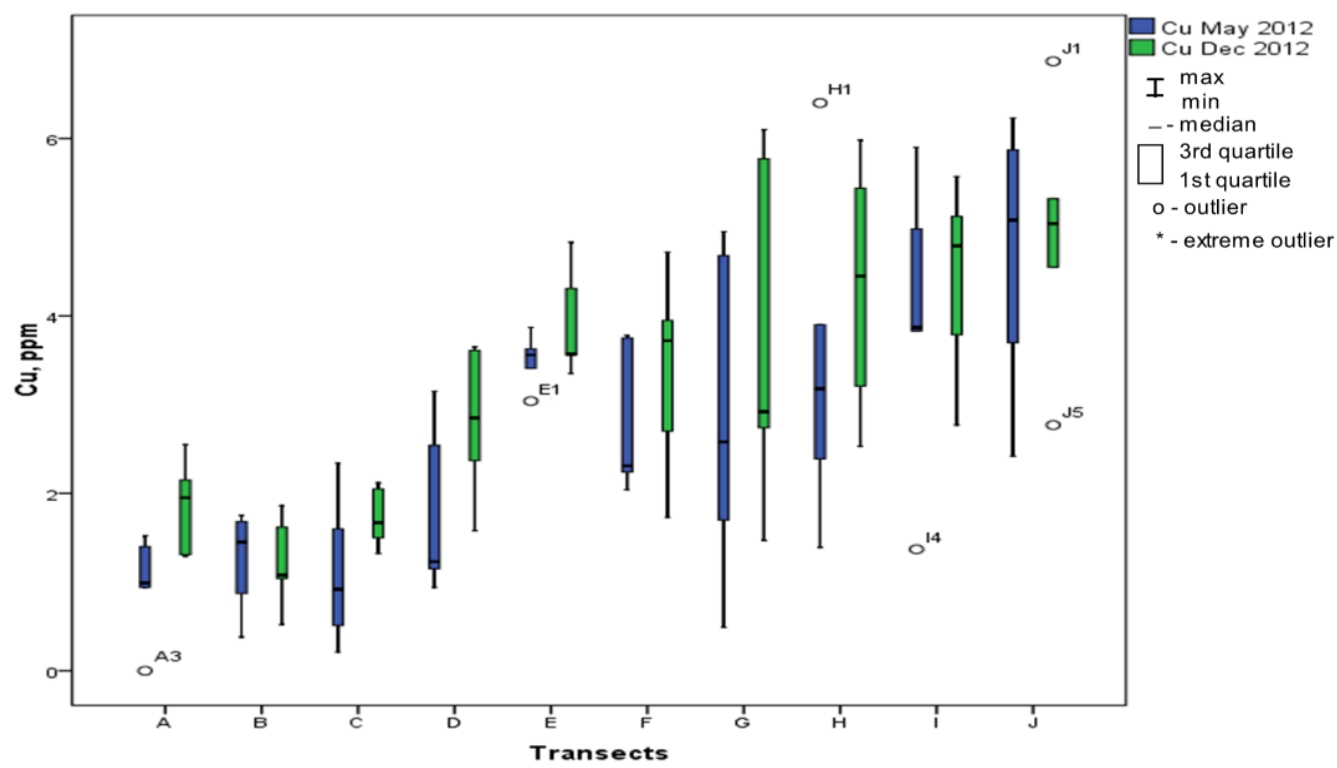

Figure 13: Copper concentration recorded from the sediment samples collected around Doha Bay during May and December 2012 sampling.

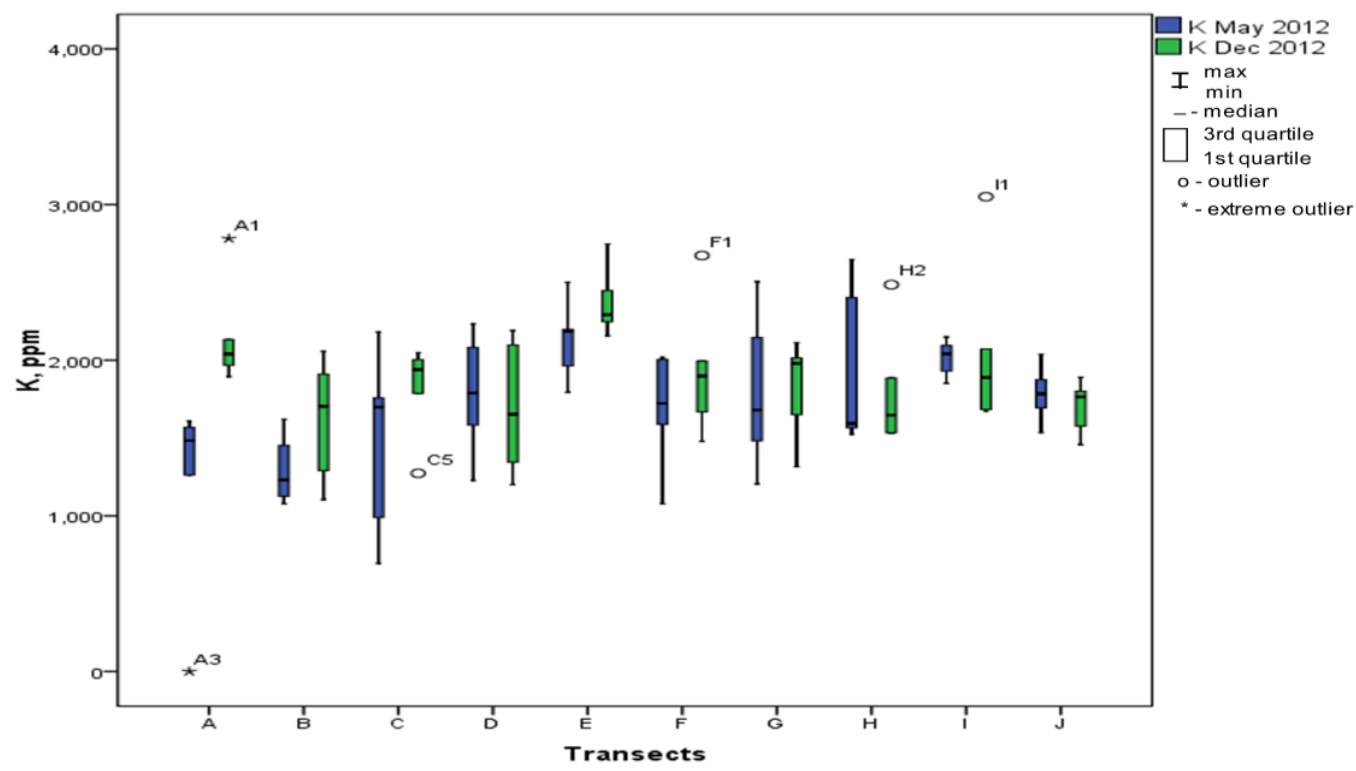

Figure 14: Potassium concentration recorded from the sediment samples collected around Doha Bay during May and December 2012 sampling. 


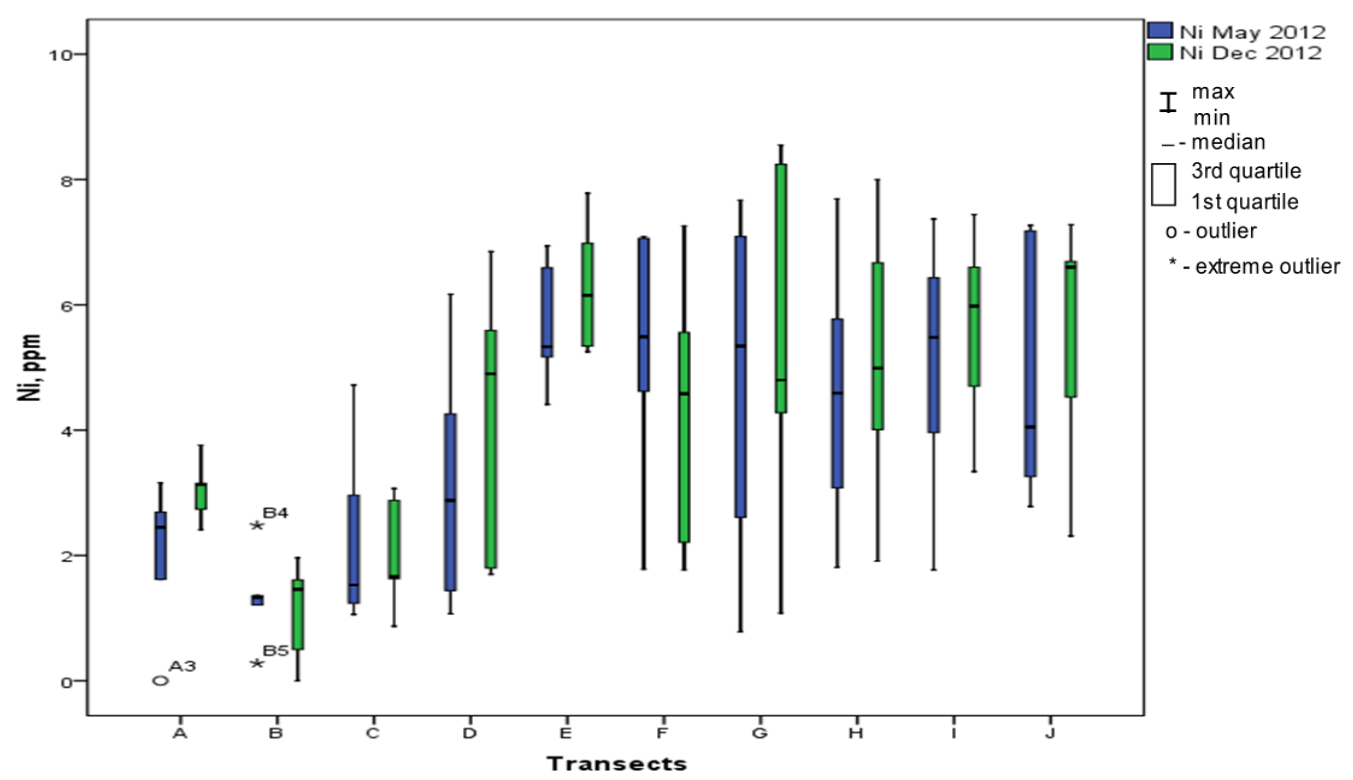

Figure 15: Nickel concentration recorded from the sediment samples collected around Doha Bay during May and December 2012 sampling.

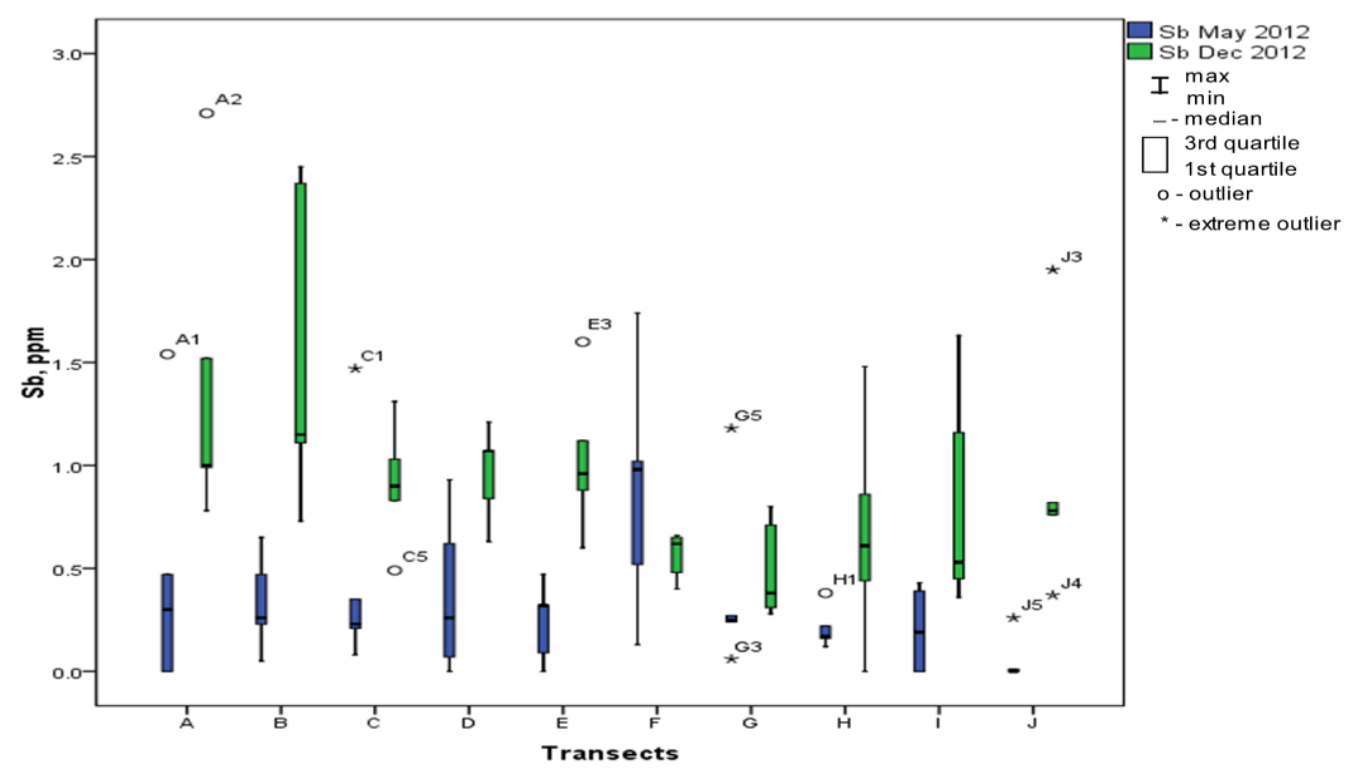

Figure 16: Antimony concentration recorded from the sediment samples collected around Doha Bay during May and December 2012 sampling. 


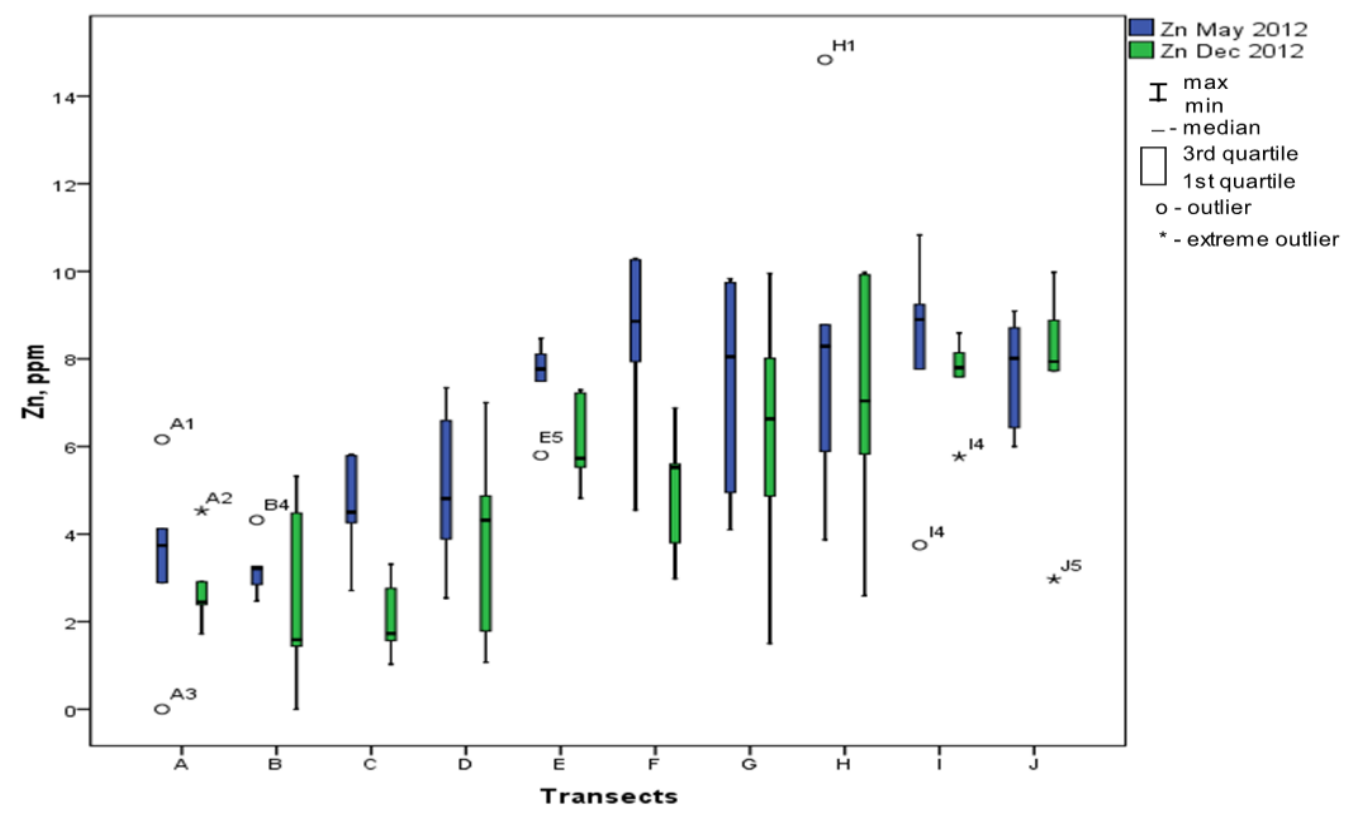

Figure 17: Zinc concentration recorded from the sediment samples collected around Doha Bay during May and December 2012 sampling. 
Table 3: Comparison of average metals concentration recorded in sediment samples surrounding Doha Bay during May 2012 (Phase I) and December 2012 (Phase II) sampling

\begin{tabular}{|c|c|c|c|c|}
\hline \multirow{2}{*}{$\begin{array}{c}\text { METALS } \\
\text { (dry } \\
\text { weight) }\end{array}$} & \multicolumn{2}{|c|}{$\begin{array}{c}\text { Phase I } \\
\text { Concentration(ppm) }\end{array}$} & \multicolumn{2}{|c|}{$\begin{array}{c}\text { Phase II } \\
\text { Concentration(ppm) }\end{array}$} \\
\hline & Min & Max & Min & Max \\
\hline Al & 507.0 & 4812 & 2130 & 6397 \\
\hline As & $<\mathrm{LOQ}$ & 2.92 & $<$ LOQ & 4.21 \\
\hline $\mathbf{B a}$ & $<\mathrm{LOQ}$ & 41.55 & 14.67 & 70.74 \\
\hline Be & $<\mathrm{LOQ}$ & 0.10 & $<\mathrm{LOQ}$ & 0.06 \\
\hline Cd & $<\mathrm{LOQ}$ & 0.27 & 0.11 & 0.48 \\
\hline Co & $<\mathrm{LOQ}$ & 1.09 & 0.21 & 0.61 \\
\hline $\mathrm{Cr}$ & $<\mathrm{LOQ}$ & 14.83 & 0.68 & 12.29 \\
\hline $\mathbf{C u}$ & $<\mathrm{LOQ}$ & 6.40 & 0.52 & 6.87 \\
\hline $\mathbf{F e}$ & $<\mathrm{LOQ}$ & 3234 & 123.0 & 2368 \\
\hline $\mathbf{K}$ & $<\mathrm{LOQ}$ & 2647 & 1104.24 & 3050 \\
\hline $\mathbf{L i}$ & $<\mathrm{LOQ}$ & 4.71 & 1.84 & 4.14 \\
\hline Mg & $<\mathrm{LOQ}$ & 47140 & 4664 & 42782 \\
\hline Mn & $<\mathrm{LOQ}$ & 53.22 & 4.42 & 54.66 \\
\hline Mo & $<\mathrm{LOQ}$ & $<\mathrm{LOQ}$ & $<\mathrm{LOQ}$ & 2.35 \\
\hline $\mathbf{N i}$ & $<\mathrm{LOQ}$ & 7.69 & $<\mathrm{LOQ}$ & 8.55 \\
\hline $\mathbf{P b}$ & $<\mathrm{LOQ}$ & $<\mathrm{LOQ}$ & $<$ LOQ & 0.67 \\
\hline Sb & $<\mathrm{LOQ}$ & 1.74 & 0.28 & 2.71 \\
\hline V & $<\mathrm{LOQ}$ & 18.17 & 1.04 & 13.51 \\
\hline Zn & $<\mathrm{LOQ}$ & 14.83 & 1.03 & 9.98 \\
\hline Hg & 0.001 & 0.037 & 0.004 & 0.031 \\
\hline
\end{tabular}

LOQ=Limit of Quantitation. See Table 1 AppendixB

Other tables and figures are shown in appendices A, B\&D. 


\subsection{Size Analysis for Sediment Samples}

Before the hot block digestion step, four randomly selected dried sediment samples were ground in agar mortar with Retsch PM400 model grinder at $100 \mathrm{rpm}$ for two different grinding times of 15 and 30 minutes. Size distribution of ground sediment samples were analyzed by using Mastersizer 2000, Hydro 2000S size distribution analyzer. Sediment samples were subjected to a different grinding time to investigate if there any significant difference between the metal concentration and the grain size. The results were comparable to both grinding times which was evident in the trace metal concentrations (Appendix A, Table3). Paired T-Test was used to evaluate the relationship. The sediment samples obtained from station A3 which was subjected under 15 min.-grinding time did not differ significantly with A3 under 30 min. $\left(\mathrm{t}_{(16)}=-0.604, \mathrm{p}>0.05\right)$ Similarly, D3-15mins, E1-15mins., and I1-15mins did not differs significantly with D330mins, E1-30mins., and I1-30mins; respectively. $\left(\mathrm{t}_{(16)}=-1.834 ;-0.906 ;-1.256\right.$, $\mathrm{p}>0.05)$ This might be affected from the digestion indicating that samples were fully digested by the selected mixture of acids. In fact, smaller particle size is preferred as this has greater surface area which will enable complete digestion of the samples which is a preparation prior to metal analysis.

The statistical analysis showed the metals concentrations of these four sediment samples (A3, D3, E1, I1) did not differ significantly in terms of grinding time but by visual inspection, each metal concentration in each station increases significantly (Figure 18). Stations A3 and D3 had lower concentrations than E1 
and I1 which was consistent with the conclusion observed on the spatial and temporal variation analysis that metal concentrations in the stations within transects $\mathrm{E}$ to I has significantly higher metal levels than transects $\mathrm{A}$ to D. Sediment grain size is one of the main controlling factors for the distribution of heavy metals in an aquatic ecosystem, however based on the results obtained; there was no significant difference between the different grinding times of the sediment. All eight sediment samples had approximately same size distribution (Figures 19 to 26). Most of all ground sediment particle sizes were found smaller than $100 \mu \mathrm{m}$. This was important for confirming reproducible results in the Hot Block digestion process and evaluating metal concentration variation dependence on grain size. According to the study of Aprile and Bouvy, 2008, they found that the concentration of metals in sediments cannot be interpreted simply by a change in grain size but other factors must be taken into consideration such as anthropogenic influences. The grain size analysis made on this study did not give a whole representation of its effects on the concentration of the metals as there were only a few stations analyzed and it is important to note that a detailed size distribution analysis on all stations within each transects must be performed to comprehend its effect. Moreover, the chemistry of the sediment and the metal itself must also be evaluated and investigated as they are also contributory factors to the contaminant levels. These include adsorption from water column or vertical mixing, $\mathrm{pH}$, oxidation of surface sediments, and biological uptake by organic matter or organisms. Physicochemical adsorption direct from the water column happens in many different ways. It usually occurs when particulate matter directly adsorb heavy metals straight from the water and high organic matter is 
proportionate to high metal levels while chemical and biological adsorption are more complicated as they are controlled by many factors such as $\mathrm{pH}$ and oxidation. Schlinder, 1991 suggested that the $\mathrm{pH}$ value oversees the adsorption of metal ions at surfaces. Higher $\mathrm{pH}$ values promote more adsorption than lower $\mathrm{pH}$ which the latter actually prevent the retention of metals by the sediment (Belzile et $a l ., 2003)$. The increase in $\mathrm{pH}$ is affected by the action of sulfate-reducing bacteria under anaerobic conditions which are present in areas where there is a lack of tidal flushing and water circulation which can be postulated from the present study as there are areas which have an enclosed compounded water system. Under these conditions, it tend to favor the formation and retention of metals as sulfides and the deposition of organic matter in these enclosed sites is expected to increase thus increasing the organic carbon due to limited mixing especially in lagoon areas. On the other hand, shallow areas which are exposed to oxygen $\left(\mathrm{O}_{2}\right)$ during changing of tides (low tide) can dry up and can influence the oxidation-reduction potential of the sediment. According to Clark et al., 1998 explained that the redox potential of the sediment can affect the metal trapping directly through change in the oxidation state of the metal itself or indirectly through a change in the oxidation state of the ions that can form complexes with the metal. It further oxidizes sulfides present to sulfuric acid thereby increasing the $\mathrm{pH}$ of the sediment pore water and allows mobilization of metals. In the present study, there are areas in Doha Bay which are consistent and comply with the description of the stated previous studies such as having an enclosed water system, shallow water and sources of anthropogenic activities which influence the level of metal concentration. It is therefore essential that a thorough investigation considering all 
these contributory factors must be made within the area to further understand the impact of the contaminants and establish comparison in future studies.

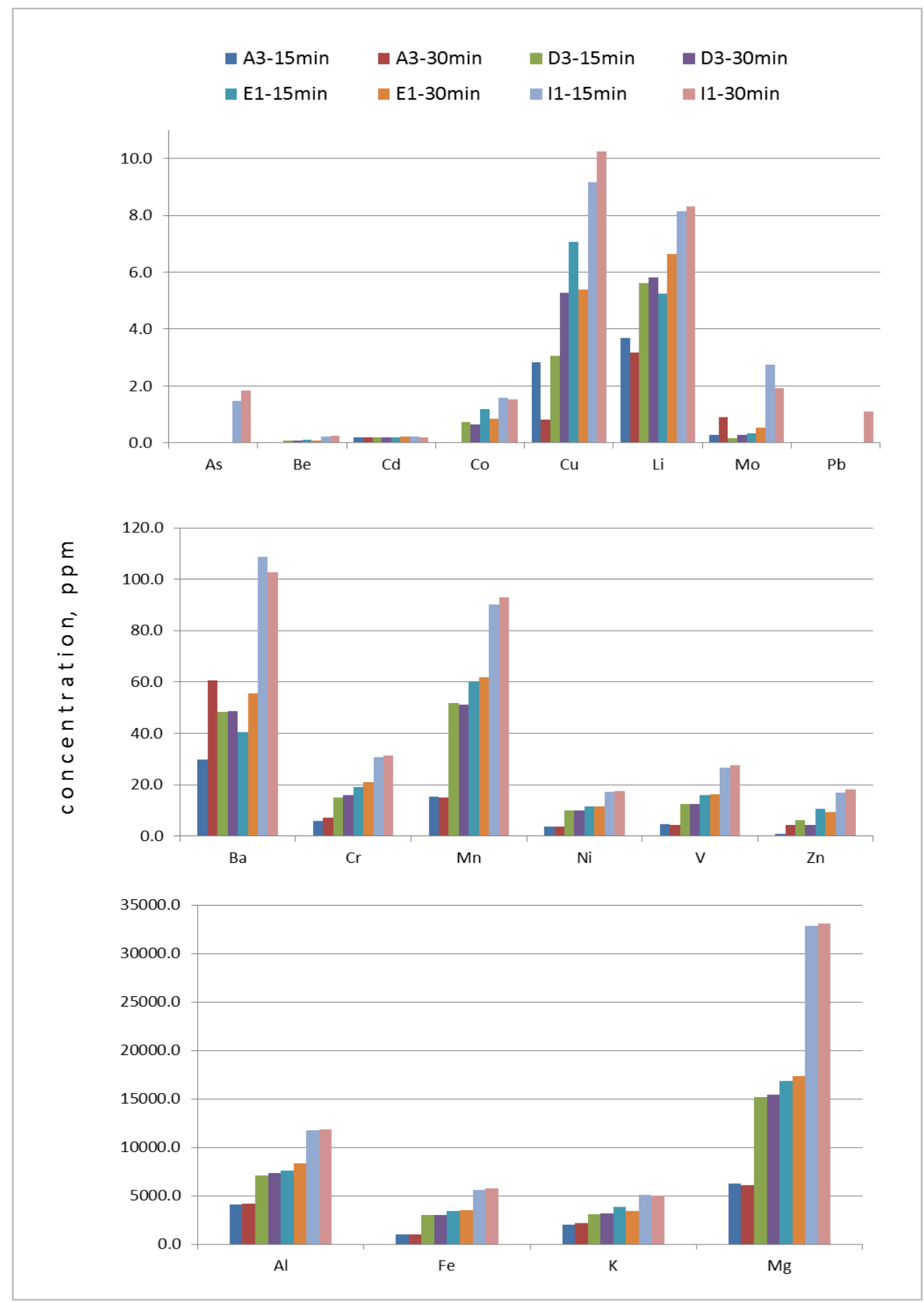

Figure 18: Comparison of metal concentrations of stations A3, D3, E1, and I1 under 15-min and 30-min grinding time. 


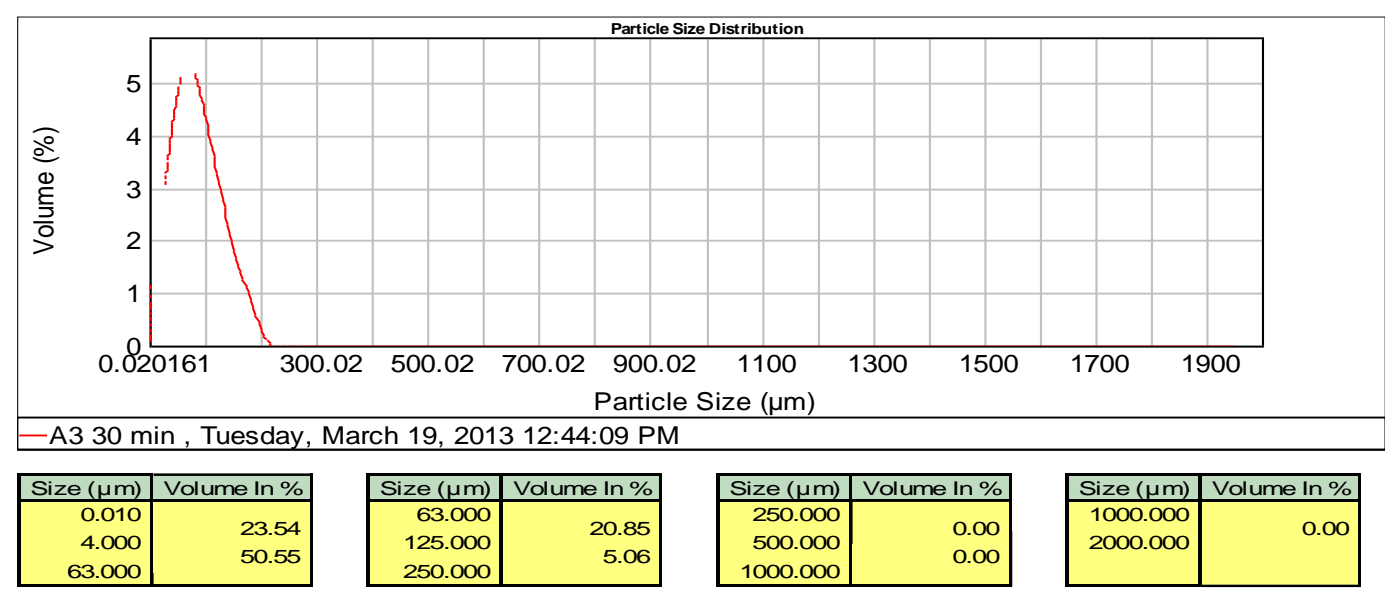

Figure 19 : Particle size distribution of station A3 (grinding time 30 minutes)

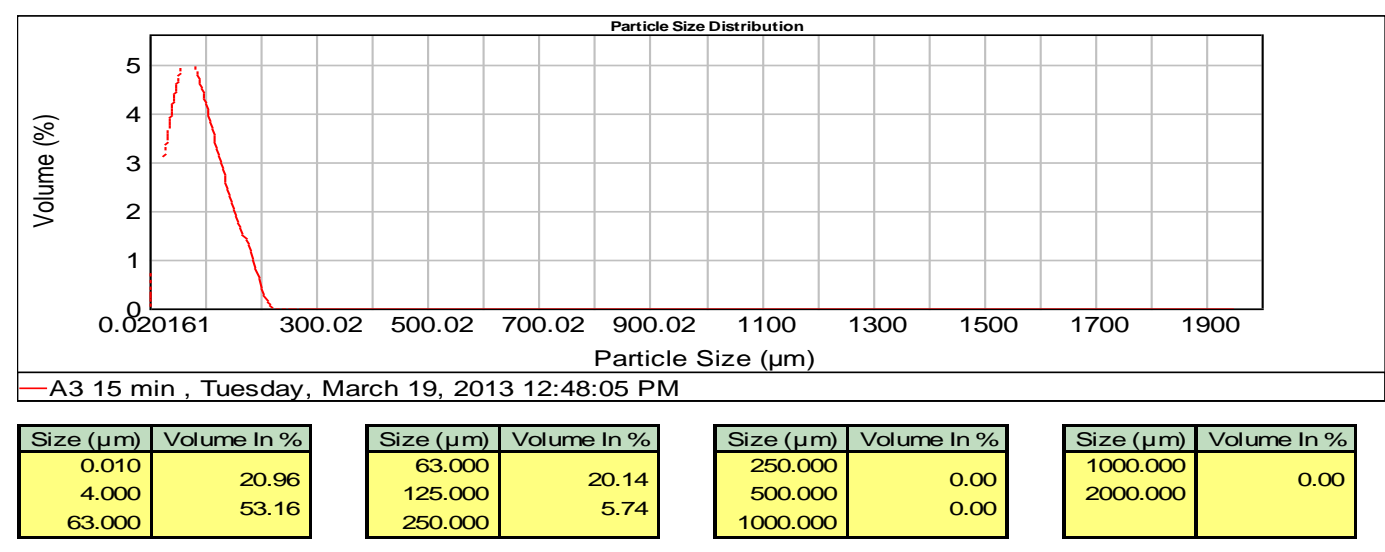

Figure 20 : Particle size distribution of station A3 (grinding time 15 minutes)

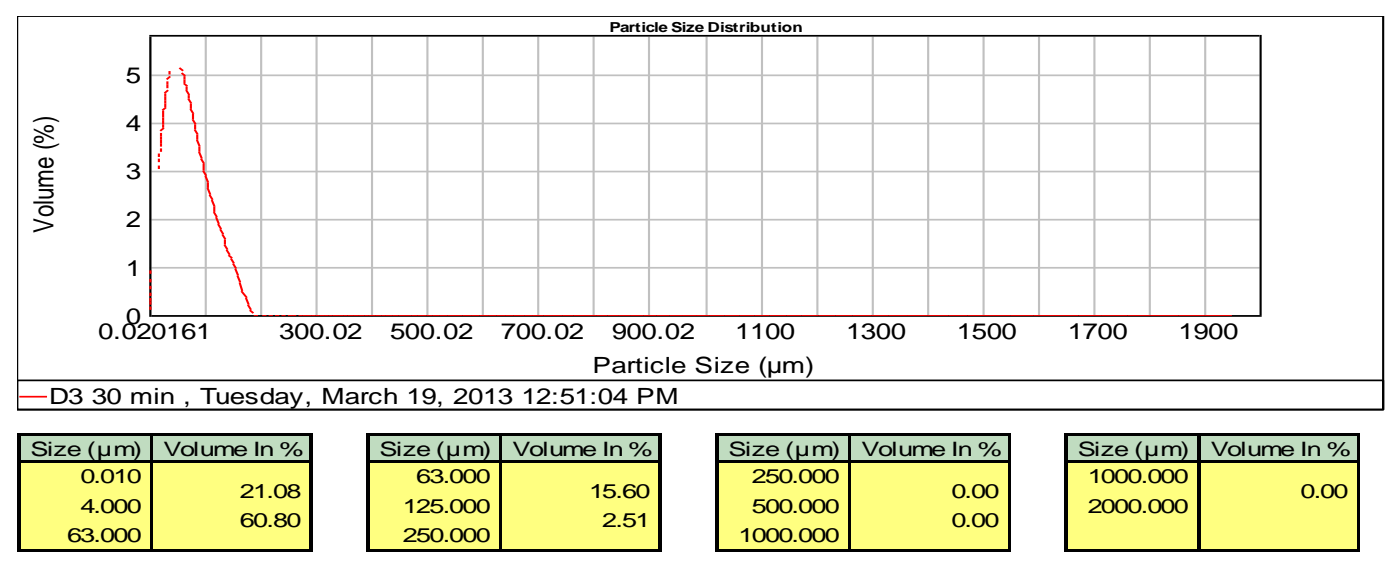

Figure 21 : Particle size distribution of station D3 (grinding time 30 minutes) 


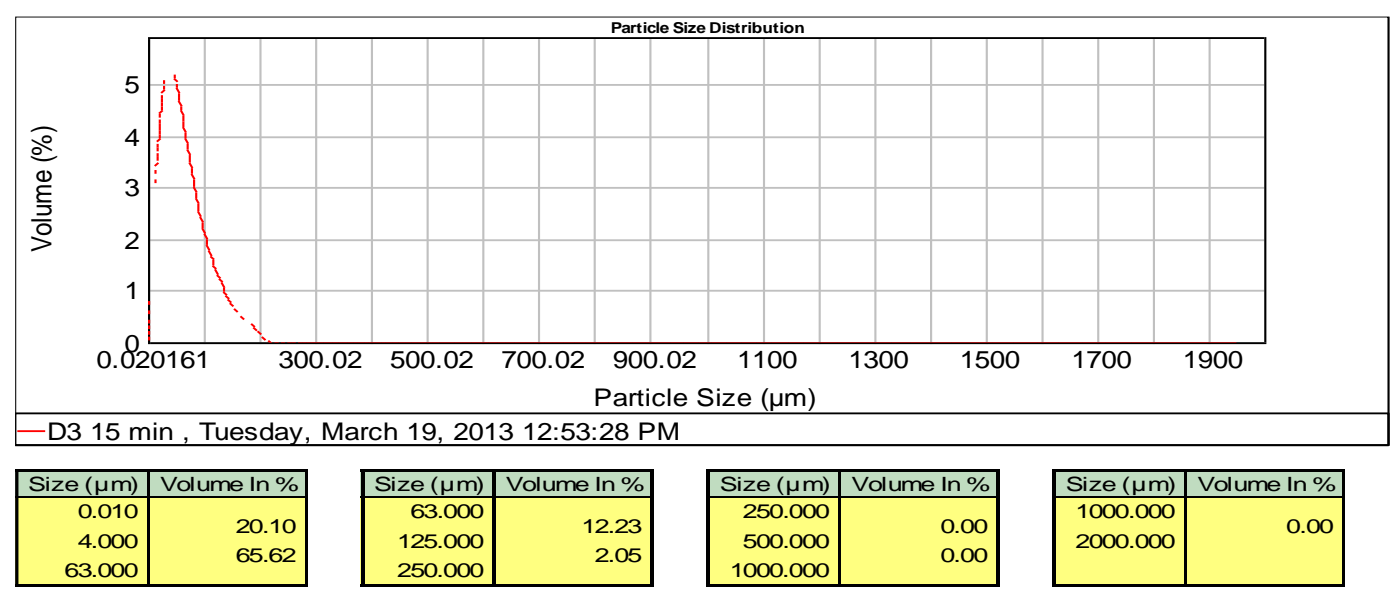

Figure.22 : Particle size distribution of station D3 (grinding time 15 minutes)

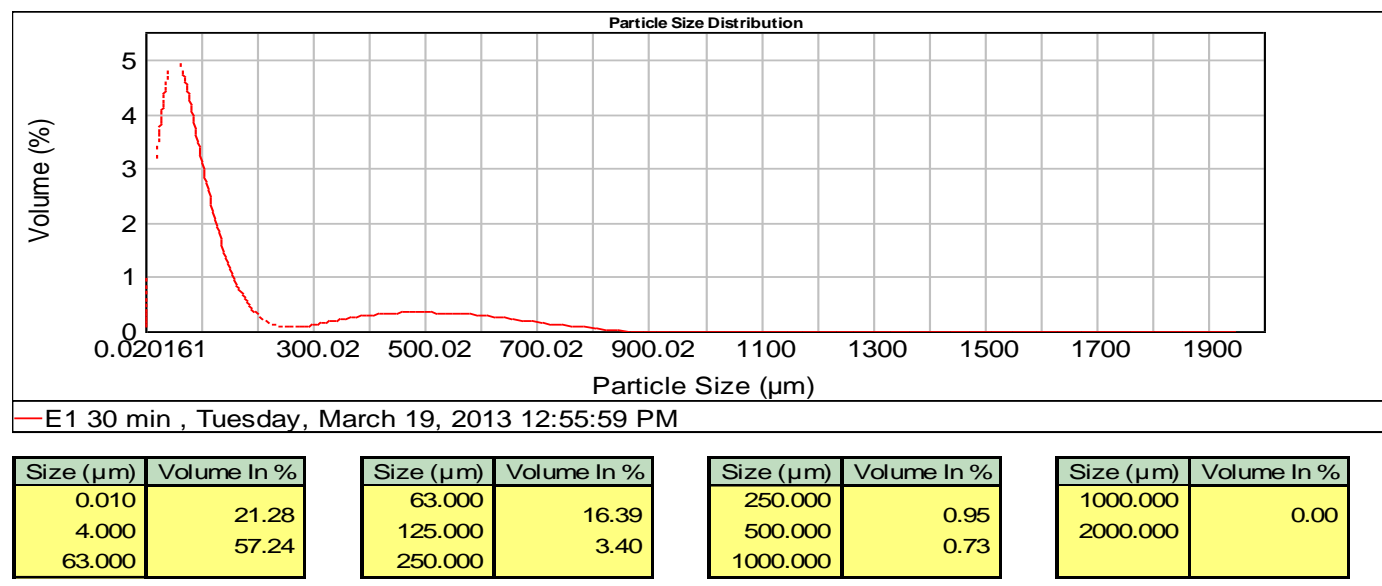

Figure 23: Particle size distribution of station E1 (grinding time 30 minutes)

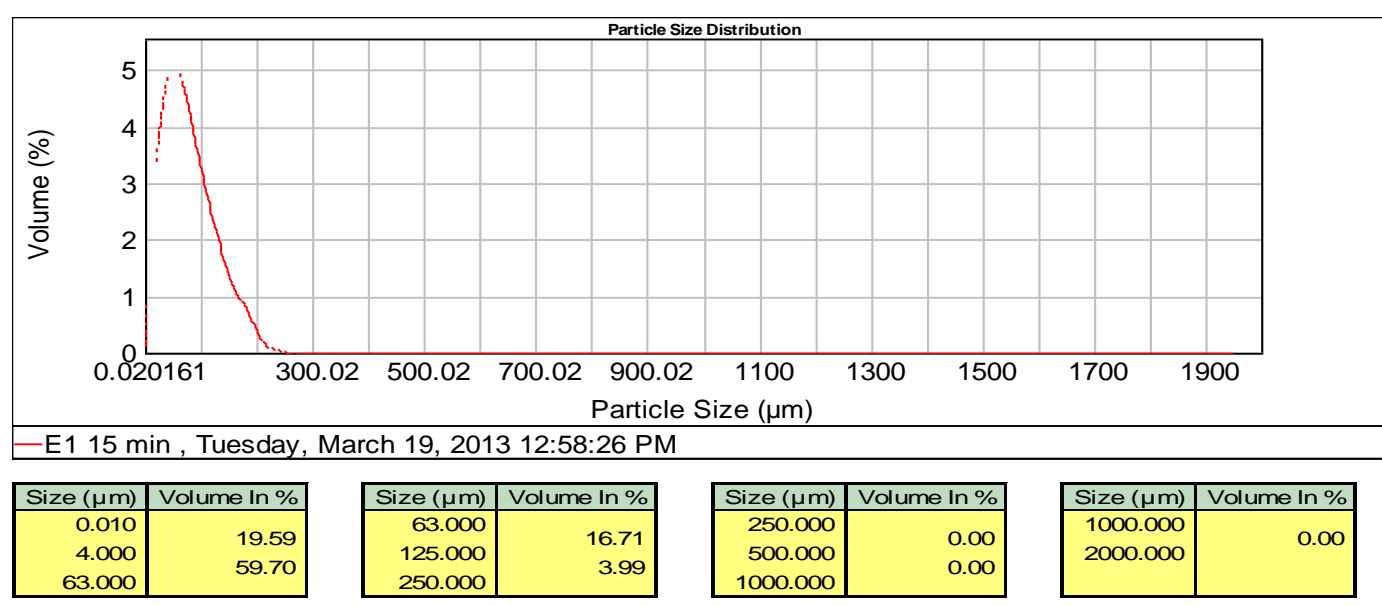

Figure 24 : Particle size distribution of station E1 (grinding time 15 minutes) 


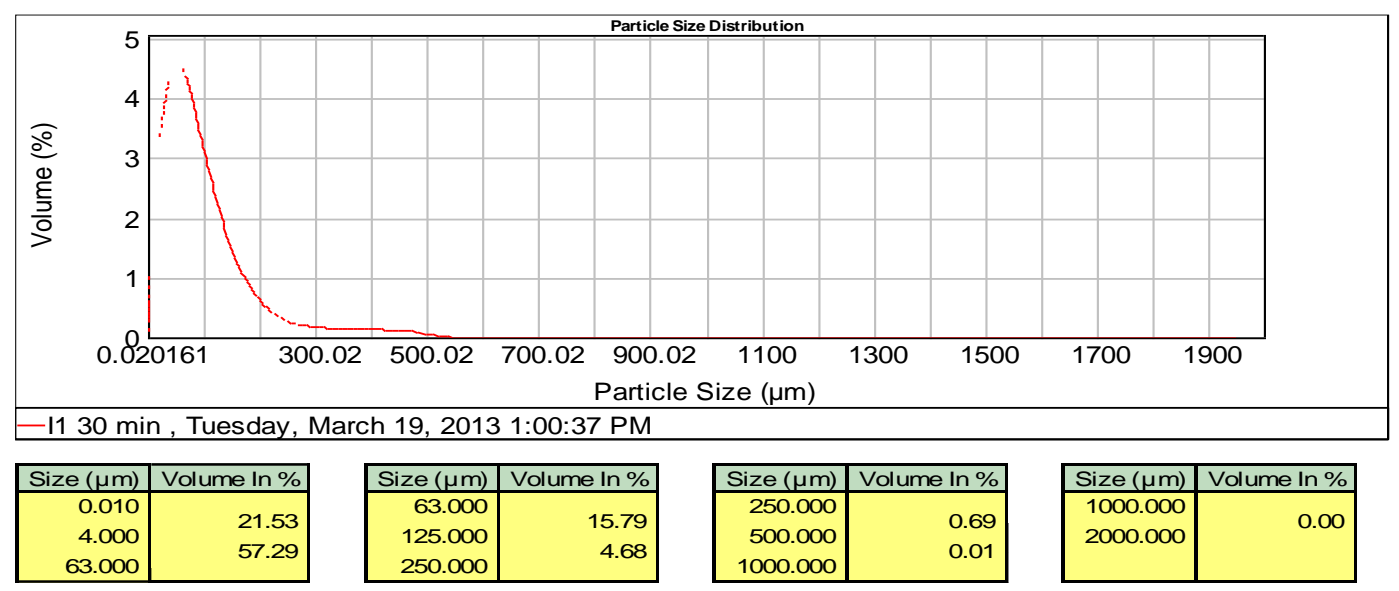

Figure25 : Particle size distribution of station I1 (grinding time 30 minutes)

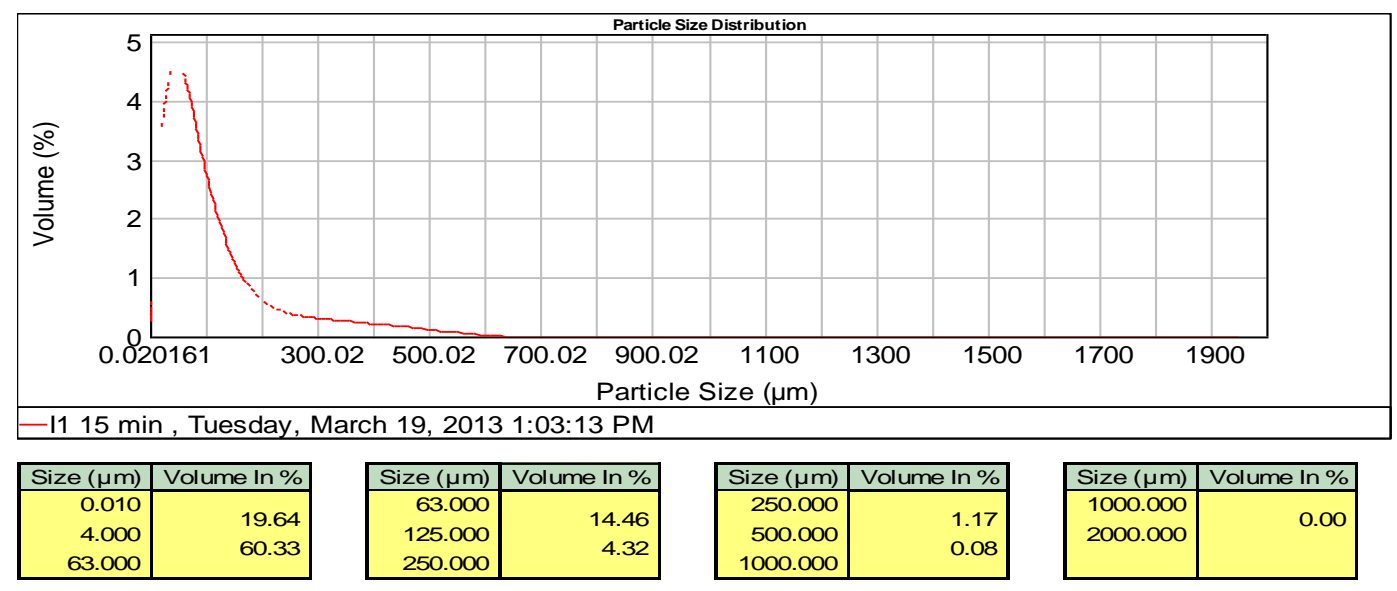

Figure 26 : Particle size distribution of station I1 (grinding time 15minutes)

\subsection{Comparison to International Guidelines and Previous Studies}

A number of international guidelines were consulted to identify if relevant published threshold criteria exist for each metal contaminant on the sediment samples investigated during the present study. The consulted international sediment quality guidelines(SQG) with its designated contaminant criteria include: 
1. Florida Department of Environmental Protection, 1994 (USA). TEL Threshold Effects Level; PEL - Probable Effects Level

2. Canadian Environmental Quality Guidelines (Canada). ISQG - Interim Sediment Quality Guideline; PEL - Probable Effect Level

3. National Oceanic and Atmospheric Administration (USA). ERL - Effects Range-Low; ERM - Effects Range-Median

The contaminant analytes that can be compared with the guidelines are As, Cd, $\mathrm{Cr}, \mathrm{Cu}, \mathrm{Ni}, \mathrm{Pb}, \mathrm{Zn}$, and $\mathrm{Hg}$. The results obtained were below the limit set by the three consulted guideline. Table 4 shows the summary of the data considered for each metal analyte during the two sampling duration while figures 27 to 32 shows the graphical representation for visual understanding.

In addition, several previous studies had been published for metal analysis on sediments samples in different locations in Qatar, UAE, Saudi Arabia, Oman and the Middle East. Comparing the results of the present study to these previous published studies will provide information regarding the magnitude of the contamination surrounding the present study area. Table 5 shows the different concentrations obtained for metal analysis from different locations in the national, the other GCC countries and international results. 
Table 4: International sediment quality guidelines summarized for consideration of contaminant levels analyzed within Doha Bay during May and December 2012 sampling.

\begin{tabular}{|c|c|c|c|c|c|c|c|c|c|c|}
\hline \multirow{2}{*}{$\begin{array}{l}\text { METALS (dry } \\
\text { weight) }\end{array}$} & \multicolumn{2}{|c|}{$\begin{array}{c}\text { Phase I } \\
\text { Concentration(ppm) }\end{array}$} & \multicolumn{2}{|c|}{$\begin{array}{c}\text { Phase II } \\
\text { Concentration(ppm) }\end{array}$} & \multicolumn{2}{|c|}{$\begin{array}{l}\text { FDEP 1994 } \\
\text { (ppm) }\end{array}$} & \multicolumn{2}{|c|}{$\begin{array}{c}\text { CEQG 2003 } \\
(\mathbf{p p m})\end{array}$} & \multicolumn{2}{|c|}{$\begin{array}{l}\text { NOAA }^{c} \\
(\mathbf{p p m})\end{array}$} \\
\hline & Min & Max & Min & Max & TEL & PEL & ISQG & PEL & ERL & ERM \\
\hline As & $<\mathrm{LOQ}$ & 2.92 & $<$ LOQ & 4.21 & 7.24 & 41.6 & 7.24 & 41.6 & 8.2 & 70 \\
\hline Cd & $<\mathrm{LOQ}$ & 0.27 & 0.11 & 0.48 & 0.7 & 4.2 & 0.7 & 4.2 & 1.2 & 9.6 \\
\hline $\mathrm{Cr}$ & $<\mathrm{LOQ}$ & 14.83 & 0.68 & 12.29 & 52.3 & 160 & 52.3 & 160 & 81 & 370 \\
\hline $\mathrm{Cu}$ & $<\mathrm{LOQ}$ & 6.40 & 0.52 & 6.87 & 18.7 & 108 & 18.7 & 108 & 34 & 270 \\
\hline $\mathbf{N i}$ & $<\mathrm{LOQ}$ & 7.69 & $<\mathrm{LOQ}$ & 8.55 & 15.9 & 42.8 & $\sim$ & $\sim$ & 20.9 & 51.6 \\
\hline $\mathbf{P b}$ & $<\mathrm{LOQ}$ & $<\mathrm{LOQ}$ & $<\mathrm{LOQ}$ & 0.67 & 30.2 & 112 & 30.2 & 112 & 46.7 & 218 \\
\hline Zn & $<\mathrm{LOQ}$ & 14.83 & 1.03 & 9.98 & 124 & 271 & 124 & 271 & 150 & 410 \\
\hline $\mathrm{Hg}$ & 0.001 & 0.037 & 0.004 & 0.031 & 0.13 & 0.7 & 0.13 & 0.7 & 0.15 & 0.71 \\
\hline
\end{tabular}

${ }^{a}$ Florida Department of Environmental Protection, 1994 (USA). TEL - Threshold Effects Level; PEL - Probable Effects Level

${ }^{\mathrm{b}}$ Canadian Environmental Quality Guidelines (Canada). ISQG - Interim Sediment Quality Guideline; PEL - Probable Effect Level

${ }^{c}$ National Oceanic and Atmospheric Administration (USA). ERL - Effects Range-Low; ERM - Effects Range-Median

LOQ=Limit of Quantitation. See Table 1 AppendixB 


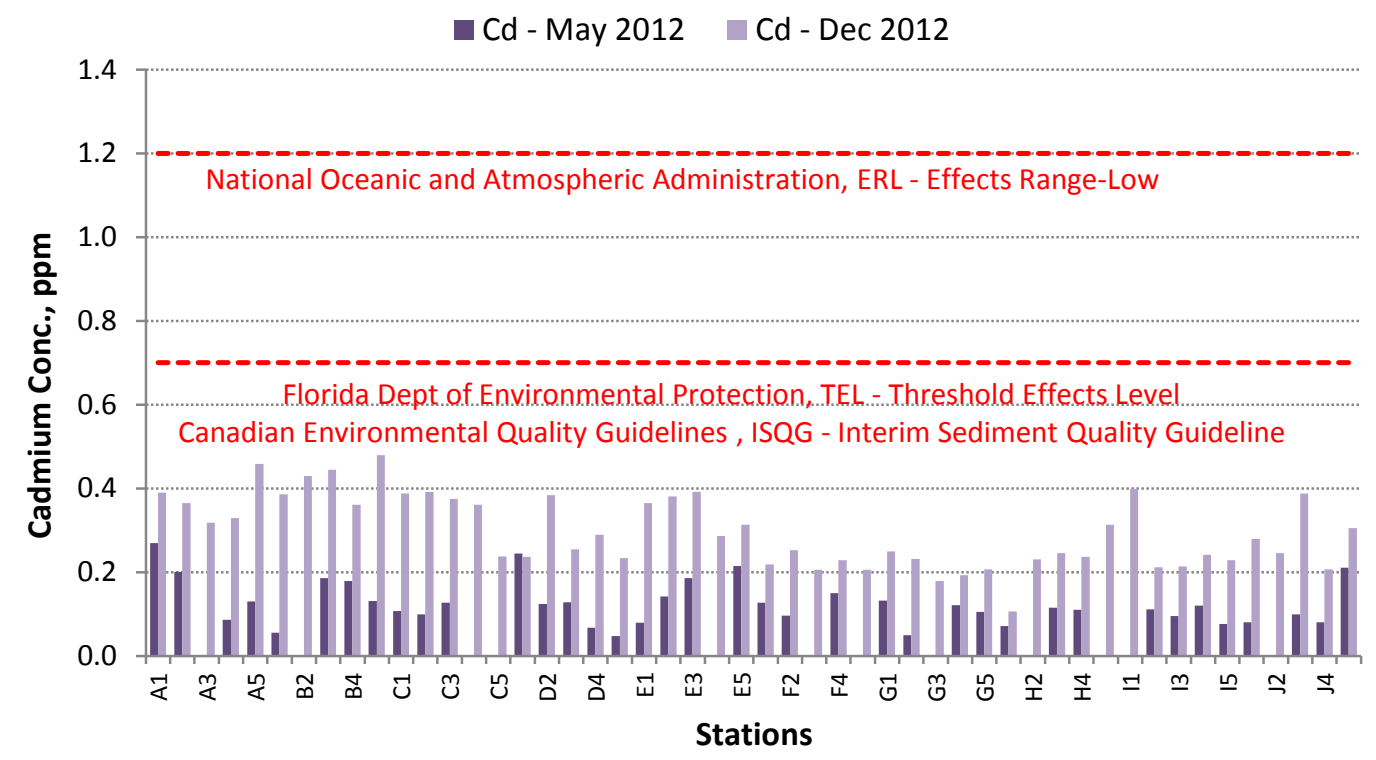

Figure 27: Cadmium concentration from sediment samples compared with international standard recorded during May and December 2012 sampling.

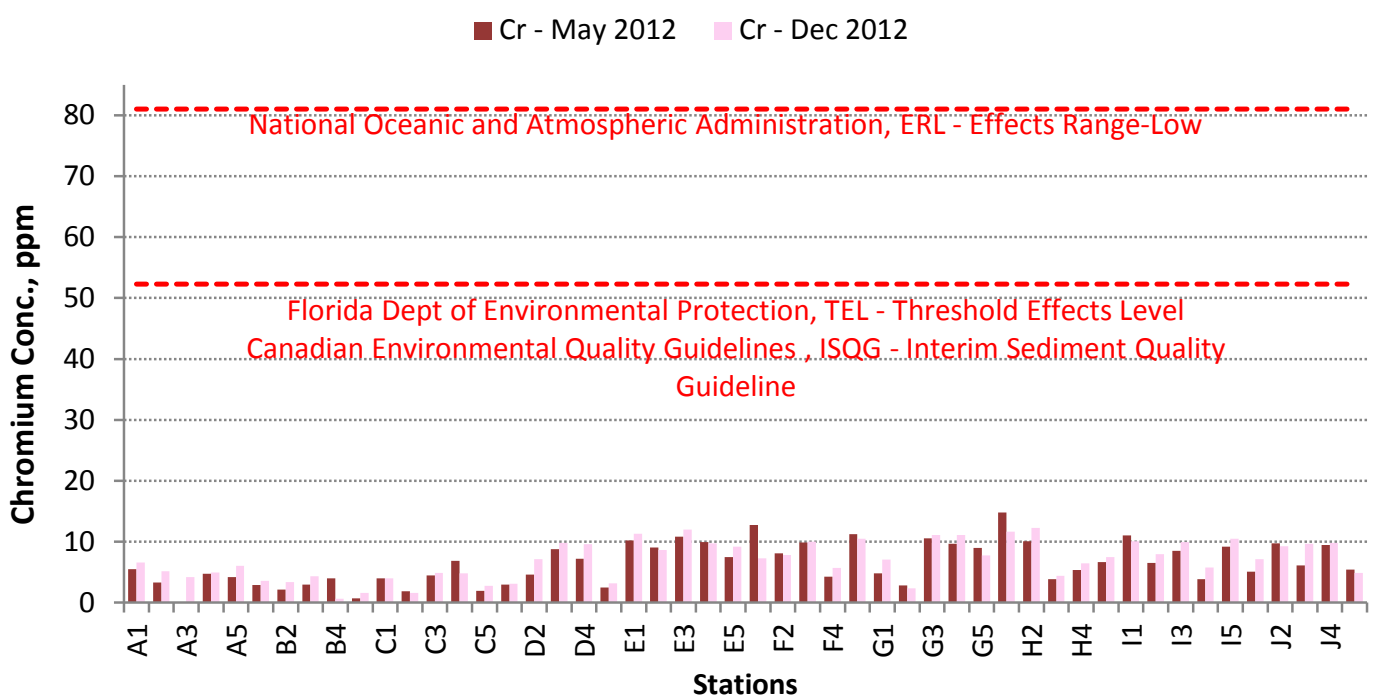

Figure 28: Chromium concentration from sediment samples compared with international standard recorded during May and December 2012 sampling. 
- Cu - May 2012 - Cu - Dec 2012

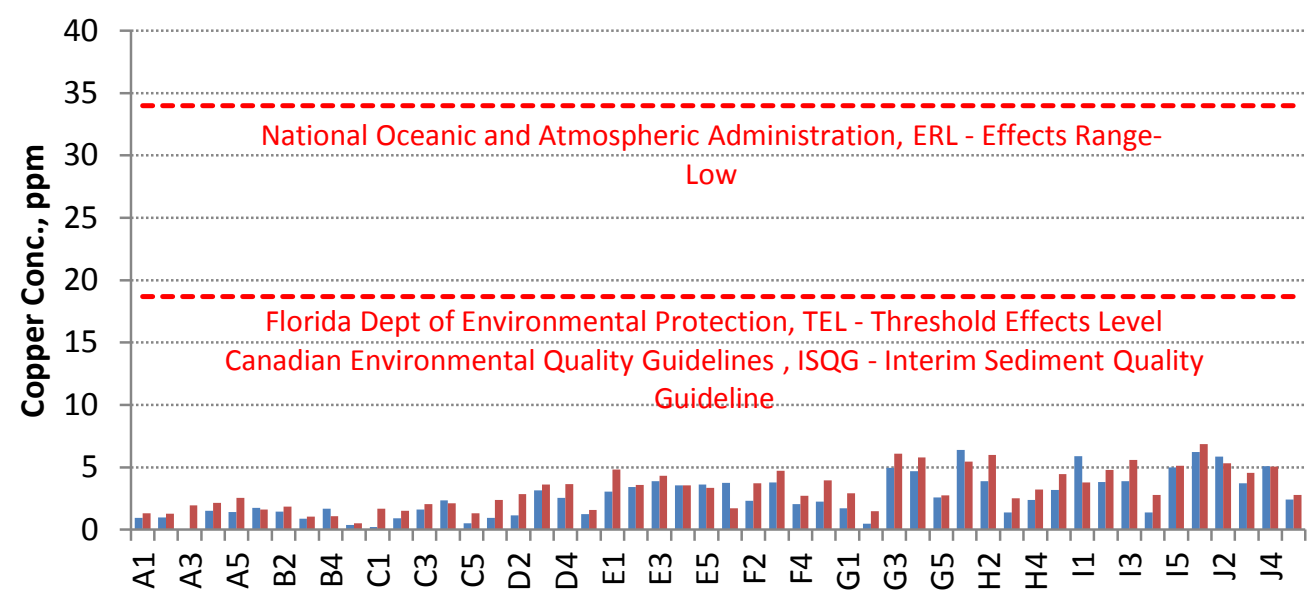

Figure 29: Copper concentration from sediment samples compared with international standard recorded during May and December 2012 sampling.

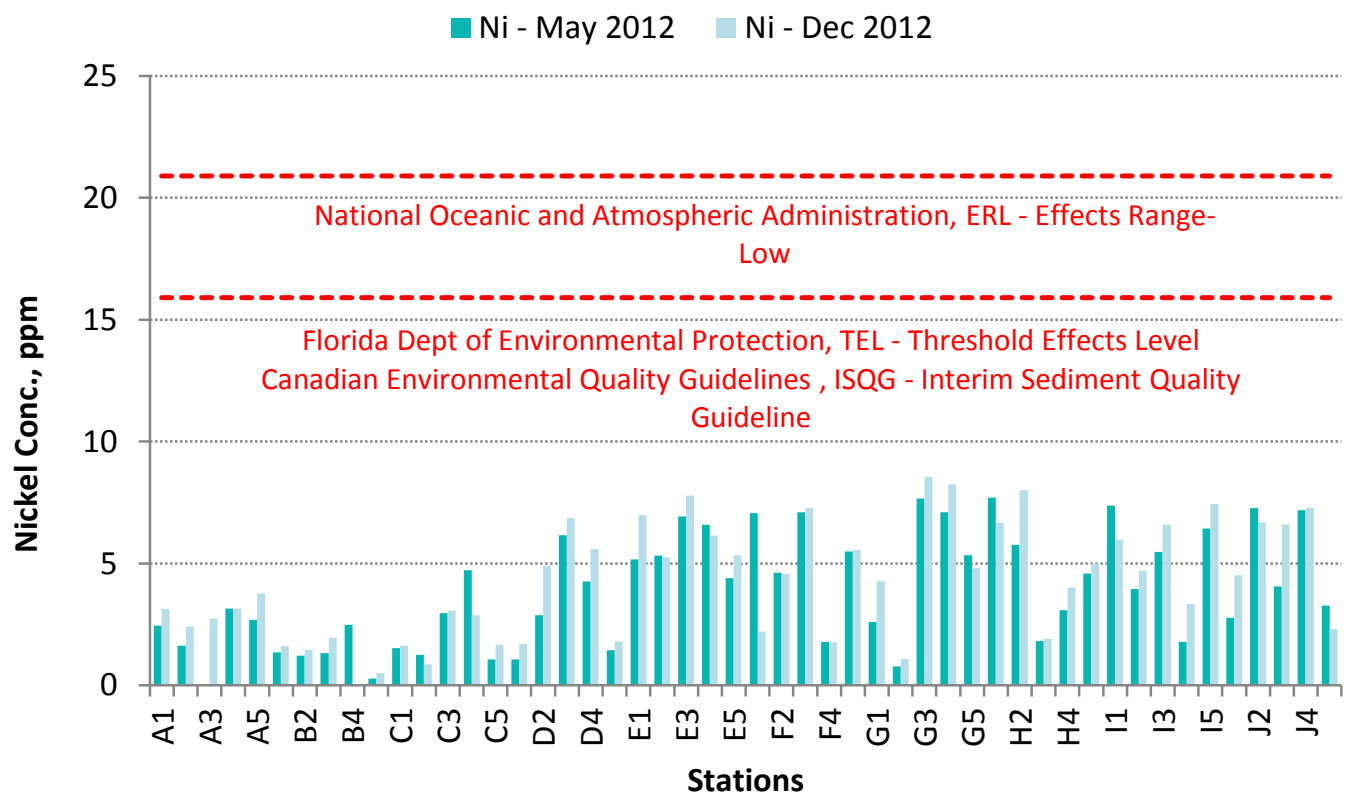

Figure 30: Nickel concentration from sediment samples compared with international standard recorded during May and December 2012 sampling. 
Zn-May 2012 - Zn-Dec 2012

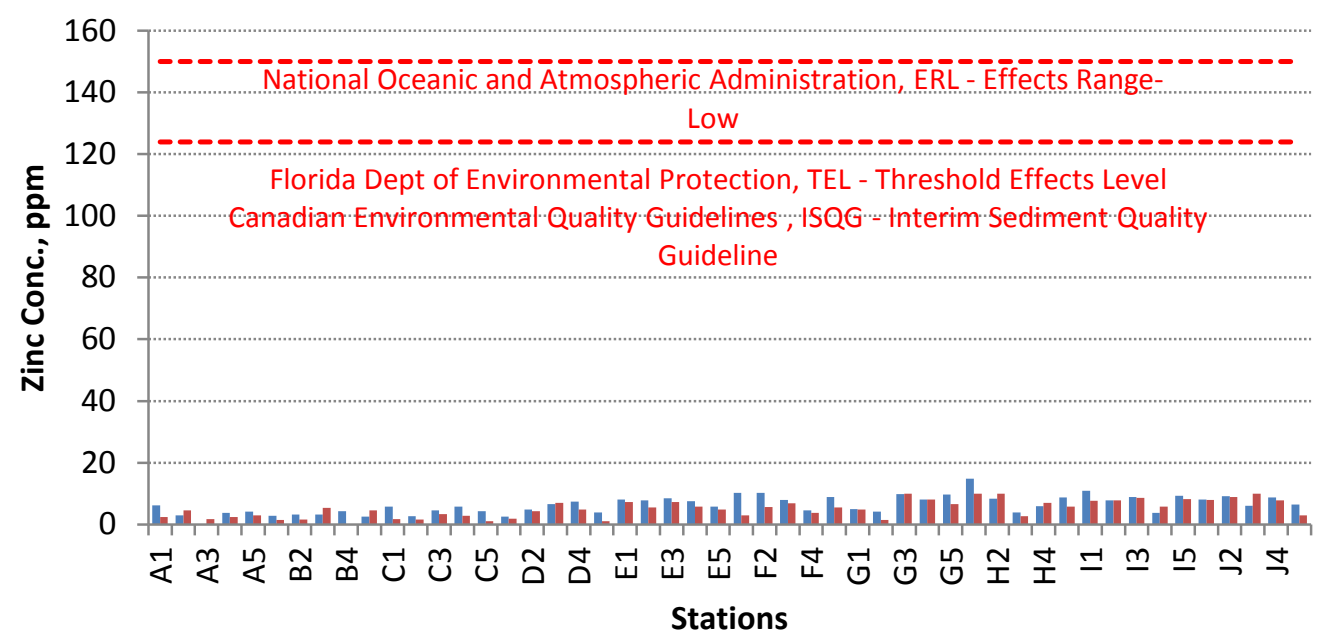

Figure 31: Zinc concentration from sediment samples compared with international standard recorded during May and December 2012 sampling.

- Hg - May $2012 \square$ Hg - Dec 2012

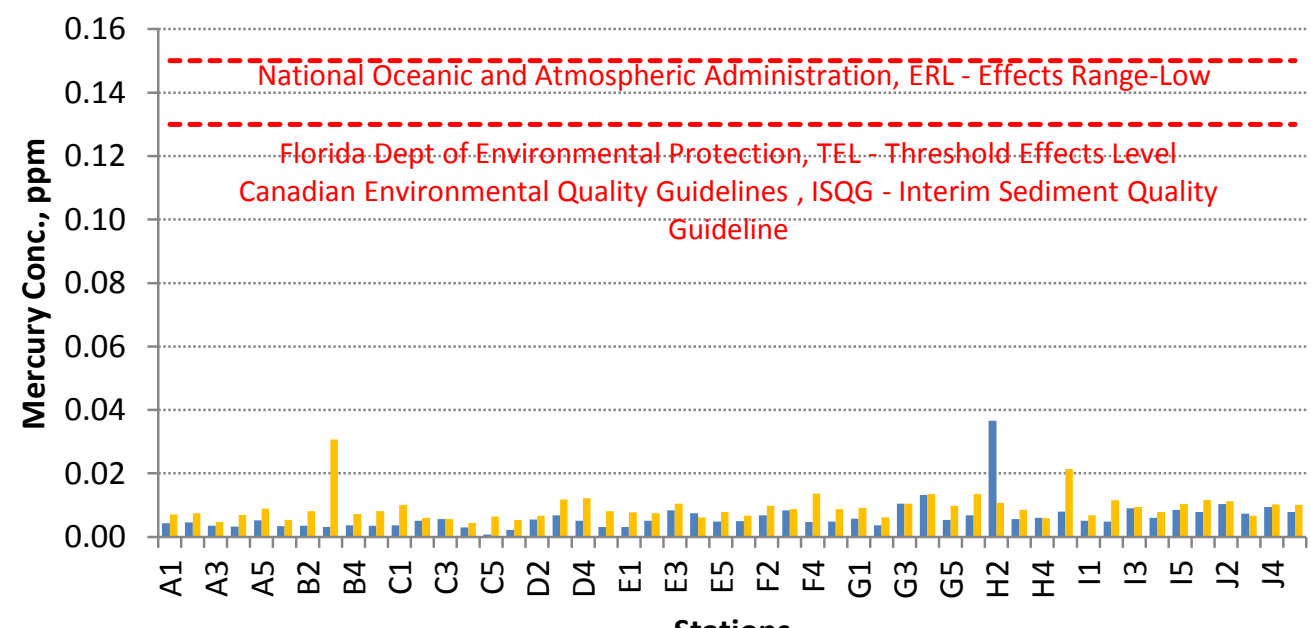

Figure 32: Mercury concentration from sediment samples compared with international standard recorded during May and December 2012 sampling. 
Table 5: Metal concentrations (ppm) recorded in sediments from the different locations.

\begin{tabular}{|c|c|c|c|c|c|c|c|c|c|}
\hline Location & $\mathrm{v}$ & $\mathrm{Mn}$ & $\mathrm{Fe}$ & Co & $\mathrm{Ni}$ & $\mathrm{Cu}$ & $\mathrm{Zn}$ & $\mathrm{Cd}$ & $\mathrm{Pb}$ \\
\hline Kuwait $^{1}$ & $85.3-133.5$ & $551-941.2$ & $1.2-2.8^{*}$ & $26.6-37.7$ & $149.5-209.1$ & $33.8-49.9$ & $91.4-126.7$ & - & - \\
\hline Saudi Arabia $^{1}$ & $2.0-48.8$ & $18.8-262.3$ & $0.002-1.95^{*}$ & nd-16.6 & $3.7-116.1$ & $1.5-27.4$ & $6.2-65.3$ & $0.089-0.25$ & $1.7-4.44$ \\
\hline Desalination effluent (Saudi Arabia) $^{3}$ & $4.73-60.56$ & $12-196$ & - & $0.72-11.32$ & $3.3-37.15$ & $<0.01-32.2$ & $2.13-33.64$ & $0.73-31.59$ & $4.72-46.33$ \\
\hline Bahrain/Qatar ${ }^{1}$ & $2.7-7.4$ & $42.8-57.2$ & $0.006-0.01 *$ & $1-1.6$ & $0.2-12.8$ & $3.8-4$ & $20.4-32.2$ & - & - \\
\hline Bahrain $^{14}$ & $4.9-36.3$ & $17.3-39.9$ & $3233-4811$ & $0.99-1.66$ & $9.4-19.6$ & $1.16-17.6$ & $2.34-3.79$ & $0.001-0.753$ & $0.64-24$ \\
\hline NE Qatar ${ }^{1}$ & $2.7-3.6$ & $17.7-52.5$ & $0.004-0.007^{*}$ & $0.4-0.6$ & $4.9-6.7$ & $2.7-3.6$ & $12.2-13.6$ & - & - \\
\hline Kuwait Coastal Sediments ${ }^{2}$ & $10-18$ & $167-500$ & $0.7-2^{*}$ & - & $55-120$ & $31-51$ & $24-89$ & - & - \\
\hline NW of Gulf $f^{4}$ & $150-186$ & $915-1643$ & $0.45-0.94 *$ & - & $386-637$ & $17.3-37.1$ & $27-43$ & - & - \\
\hline $\mathrm{UAE}^{14}$ & $7.3-70.1$ & $96.7-231$ & $3594-6055$ & $1.79-3.3$ & $14.2-25$ & $1.34-7.76$ & $1.56-3.40$ & $0.018-1.91$ & $0.54-5.21$ \\
\hline UAE Coastal $^{7}$ & - & $5.03-352$ & - & $6.01-25.93$ & $8.01-214.5$ & $3.05-79$ & $3.01-534$ & $4.32-9.55$ & $9.03-57.01$ \\
\hline Oman $^{14}$ & $10.2-123$ & $89.1-310$ & $5051-22749$ & $1.98-22.1$ & $9.9-439$ & $1.61-13.9$ & $7.7-26.3$ & $0.03-0.926$ & $0.37-25.9$ \\
\hline $\operatorname{Iraq}^{5}$ & - & $35-78$ & & 01-Mar & May-14 & $1.5-5.3$ & Aug-28 & $0.1-1.0$ & 03-Jun \\
\hline Baltic Sea ${ }^{11}$ & 130 & 4030 & 7.7 & 22 & 43 & 78 & 110 & - & - \\
\hline Ligurain Coastal Sediments $^{12}$ & - & - & 4.1 & & 130 & 39 & - & - & - \\
\hline North-Western Black Sea ${ }^{6}$ & $1-118$ & - & - & $1-71.59$ & $1-117$ & $4.62-75.72$ & $1-174$ & $0.16-3.99$ & $2.1-43.5$ \\
\hline Harbour Island, Gulf of Mexico ${ }^{13}$ & - & - & - & - & $5-10.9$ & - & $14-28$ & $0.4-1.1$ & $3.4-9.0$ \\
\hline North Sea $^{8}$ & - & - & - & - & $6.5-22$ & - & $19.7-197.5$ & $0.1-0.8$ & $17-238$ \\
\hline Koahsiung Harbour,Tawian ${ }^{9}$ & - & - & - & - & $42-285$ & - & $103-3514$ & $0.3-1.8$ & $26-576$ \\
\hline Narangansett Bay, USA ${ }^{10}$ & - & - & - & - & Jun-34 & - & $53-168$ & $0.1-2.5$ & $17-81$ \\
\hline Caspian Sea sediments Iran ${ }^{15}$ & $76.5-145$ & $470-1111$ & $22231-44035$ & $6.91-24.2$ & $29.4-67.8$ & $13.2-50.9$ & $55.9-149$ & $0.098-0.244$ & $11.3-24.6$ \\
\hline Umm Bab (Qatar) Nearshore ${ }^{16}$ & $0.653-8.398$ & $13.05-75.17$ & $77.615-1177.58$ & $0.445-2.02$ & $1.839-6.981$ & $1.353-6.457$ & $8.03-25.23$ & $2.71-13.35$ & $0.95-17.83$ \\
\hline PS3 $2008^{16}$ & $2.81-12.74$ & $8.09-70.00$ & $558-4054$ & $0.29-2.04$ & $4.36-14.00$ & $<$ LOD-6.56 & $6.41-91.61$ & $<$ LOD-0.49 & $<$ LOD-29.72 \\
\hline RLIC 2010 (Qatar) $^{16}$ & $0.93-4.87$ & $4.80-27.94$ & $163.18-848.43$ & $<$ LOQ-1.74 & $<$ LOQ-2.30 & $<$ LOQ-4.52 & $<$ LOQ-8.66 & $<$ LOQ-<LOQ & $<L O Q-<L O Q$ \\
\hline Present Study - Phasel & $<$ LOQ-18.17 & $<$ LOQ-53.22 & $<$ LOQ-3233.51 & $<$ LOQ-1.09 & $<$ LOQ-7.69 & $<$ LOQ-6.40 & $<$ LOQ-14.83 & $<$ LOQ-0.27 & $<\mathrm{LOQ}$ \\
\hline Present Study - Phasell & $1.04-13.51$ & $4.42-54.66$ & $123.04-2368.46$ & $<$ LOQ-0.61 & $<$ LOQ-8.55 & $0.52-6.87$ & $1.03-9.98$ & $0.11-0.48$ & $<$ LOQ-0.67 \\
\hline
\end{tabular}

Sources: Ali and Al-Lihaibi (1993) ${ }^{1}$, Anderlini et. al. (1987) ${ }^{2}$, Muhammad Sadiq (2002) $)^{3}$ Abayachi and DouAbul, $(1986)^{4}$, Al-Hashimi, AH, Salman HH (1985) $)^{5}$, D. Secrieru and A. Secrieru. $(2004)^{6}$, M. A. Shriadah $(1999)^{7}$, Shiber (1979) ${ }^{8}$ and9, Eisler et al.

$(1977)^{10}$, Manheim $(1961)^{11}$, Cosama et $a l,(1982)^{12}$, Roth \& Hurnung $(1977)^{13}$, Fowler et al $(1993)^{14}$, Stephen de Mora and Mohammad Reza Sheikholeslami. (2004) ${ }^{15}$, E.S. Center, QU ${ }^{16}$ 


\subsection{Interferences}

By definition, an interference enhances or depresses the intensity of the analyte, resulting in an incorrect result recorded (Alloway 1995). The followings are some of the interferences that occurred during this project.

- spectral overlap caused by some elements especially polyatomic species on elements of interest $(\mathrm{Cd}, \mathrm{Pb}, \mathrm{Cr}$, and $\mathrm{Hg})$ that was overcome by direct correlation with the certified reference material (CRM) that helped select the desired wave length of each element.

- Warm -up of ICP instrument is necessary to insure sufficient temperature level suitable for analyses. Checking gas line (Argon gas) and statues of instrument prior to analyses is a must.

- Purity of reagent including water is a very important issue to avoid interference with the metals being analyzed and to enable instrument to run in optimum condition, i.e. reduce contamination. UltraPure grade reagents and high quality deionized water should cure this problem. 


\section{Chapter 5. CONCLUSION AND PERSPECTIVES}

The study analyzed the concentrations of 25 metals around Doha Bay to evaluate the pollution loading and the magnitude of the impact that the contaminant had on the sediment samples within the area on two sampling duration. Significant differences were observed between the temporal variation which December 2012 sampling (phase II) recorded higher concentration than May 2012 (Phase I). Moreover, there were significant differences in spatial variation which was observed between the 10 transects consisting of 5 stations each. Higher metals concentrations were recorded in transects E to I compared with A to D. The areas with higher levels has many anthropological activities, however the concentrations were still within limit to some metals which FDEP, CEQG, and NOAA (international standards) had set permissible levels. Sediment grain size was also determined in the study which obtained no significant differences between the metal concentration and difference in grinding time (15 and 30 minutes). However, the data were not conclusive as there were only 4 sediment samples analyzed although the results were consistent and representative of the transects with increased anthropological activities thus with higher metals concentrations: E1 and I1 and lower metals concentrations: A3 and D3. Based on this result, it was evident that sediment grain size not only affects the contaminant levels in the area but there may be other contributory factors that influence the measured concentrations. It is therefore recommended that a detailed comprehensive environmental impact assessment be undertaken within the study area and should be 
done annually to evaluate the changes in the environmental status as it is predicted that increased activities will happen within the area due to commercialization and development. A number of actions are recommended to improve our understanding of heavy metal processing and its impacts in addition to enhance and improve the monitoring and reporting of results of this present study. The following include:

- Deployment of current meters to measure the current direction, value and change during different weather conditions.

- Conduct detailed monitoring scheme water quality survey and biota analysis in order to obtain representative values within the ecosystem of the area..

- Execute hydrodynamic modeling to understand water hydrodynamic of the area.

- Study siltation plume associated with dredging and the fate of the released sediments.

Recommended monitoring studies will serve as a purpose for identification of highrisk areas, and obtain information on sampling, assessment protocols, and techniques. In addition preventative assessments and measurements to limit exposure and dispersion of contaminated sediments (e.g. low impact dredging technologies, siltation booms and curtains) are essential in the investigation to provide conclusive analysis within the study area. These assessment and measurements must include a wide range of parameters such as: 
- Physico-chemical analyses such pH, conductivity, salinity, and turbidity

- Nutrient loading

- Organic Carbons and other hydrocarbons i.e. polycyclic aromatic hydrocarbons (PAHs), Total Petroleum Hydrocarbons (TPHs), Volatile Organic compounds (VOC)

- Sulfate-Reducing Bacteria

- $\quad$ Acid Volatile Sulfide (AVS)

- Redox potential in sediment

- Sediment Biochemical Oxygen Demand (SBOD) and BOD5

- Sediment Rate Analyses 


\section{REFERENCES}

1. Abayachi, K.J., and A AZ. Douabul, 1986. Trace element geochemical association in Arabian Gulf. Marine. Pollution. Bulletin 17, 353-356.

2. Al-Hashimi, A. H. and Salman, H. H., 1985. Trace metals in the sediments of the northwestern coast of the Arabian Gulf. Marine Pollution Bulletin 16, 118120.

3. Anderlini, V., Samhan, O., Zarba, M., 1987. Multivariate geochemical investigation of trace metal pollution in Kuwait marine sediments. Marine Environmental Research 21, 31-48.

4. Aksu, A.E., Yasar, D., Uslu, O., 1998. Assessment of marine pollution in Izmir Bay: heavy metal and organic compound concentrations in surficial sediments. Tr. J. Eng. Environ. Sci. 22, 387-415.

5. Alloway, B.J., 1995. Heavy metals in soils. Blackie Academic \& Professional. Second Edition, 368p.

6. Allen, H.E., 1995. Metal Contaminated Aquatic Sediments. Michigan, Ann Arbor Press.

7. Ansari, T.M., Marr, I.L., Tariq, N., 2004. Heavy Metals in Marine Pollution Perspective- A Mini Review. J. Appl. Sci. 4, 1-20.

8. Aprile, F.M. and Bouvy, M., 2008. Distribution and Enrichment of Heavy Metals in Sediments at the Tapacura River Basin, Northeastern Brazil. Braz. J. Aquat. Sci. Technol. 12, 1-8. 
9. Barceloux, D.G., 1999. Cobalt. Clinical Toxicol. 37,201-216.

10. Basahan, Ali and Al-Lihaibi, Sultan, 1993. Trace Elements in Sediments of the Western Gulf. Marine Pollution Bulletin 27, 103-107.

11. Basaham, A.S. and El-Sayed, M.A., 1997. Estuarine, Coastal and Shelf Science. 46, 185-194.

12. Begum, A., HariKrishna, S., Khan, I., 2008. Chemical Composition of Rrainwater in South Bangalore, Karnataka, Rasayan. J. Chem. 1, 774-781.

13. Begum, A., HariKrishna, S., Khan, I., 2009. Analysis of Heavy metals in Water, Sediments and Fish samples of Madivala Lakes of Bangalore, Karnataka. Int. J. of Chem. Tech. Res. 1, 245-249.

14. Belize, N., Chen, Y., Gunn, J., Dixit, S., 2004. Sediment trace metal profiles in lakes of Killarney Park, Canada: from regional to continental influence. Environmental Pollution 130, 239-248.

15. Binning, K. and Baird, D., 2001. Survey of heavy metals in the sediments of the Swartkops River Estuary, Port Elizabeth South Africa. Water South Africa $27,461-465$.

16. Bland, J.M., 2001.Calculating Confidence intervals, Britsh Medical journal 312,772 .

17. Brown, N.J. and Peake, B.M, 2006. Sources of heavy metals and polycyclic aromatic hydrocarbons in urban storm water runoff. Sci. Total Environ. 359, $145-155$ 
18. Burden, F.K., McKelvie, I., Forstner U., and Guenther A., 2002. Environmental Monitoring Handbook. eBook, McGraw-Hill Company.

19. Burton, J.D. and Statham, P.J., 2000. Trace Metals in Seawater, in R. W. Furness \& P. S. Rainbow (ed.), Heavy Metals in the Marine Environment, CRC Press, Inc, Florida, United States of America.

20. Chandra, S, 2002. Investigations into the Lami municipal dump as a source of heavy metal contamination, Thesis, University of the South Pacific (USP).

21. Chen, Z., Kostaschuk, R., Yang, M., 2001. Heavy metals on tidal flats in the Yangtze Estuary, China. Environ. Geol. 40, 742-749.

22. Clark, M.W., McConkie, D., Lewis, D.W., Saenger. P., 1998. Redox stratification and heavy metal partitioning in Avicennia-dominated mangrove sediments: a geological model. Chemical Geology 149, 147-171.

23. Cosma, B., Frache, R., Baffi, F., Dadone, A., 1982. Trace metals in sediments from the Ligurian Coast, Italy. Marine Pollution Bulletin 13, 127-132.

24. David, C.P., 2003. Heavy metal concentrations in growth bands of corals: a record of mine tailings input through time. Marine. Pollution. Bulletin 46, 187-196.

25. De Mora, Stephen; Sheikholeslami, Mohammad Reza; Wyse, Eric; Azemard, Sabine; Cassi, Roberto, 2004. An assessment of metal contamination in coastal sediments of the Caspian Sea. Marine Pollution Bulletin 48, 61-77.

26. Denton, G.R.W., Bearden, B.G., Concepcion, L.P., Siegrist, H.G., Vann, D.T., Wood, H.R., 2001. Contaminant Assessment of Surface Sediments from 
Tanapag Lagoon, Saipan, Water and Environmental Research Institute of the Western Pacific, Technical Report No. 93, University of Guam, Mangilao, Guam.

27. Denton, G.R.W., Wood, H.R., Concepcion, L.P., Siegrist, H.G., Eflin, V.S., Narcis, D. K., Pangelinan, G.T., 1997. Analysis of In-Place Contaminants in Marine Sediments from Four Harbor Locations on Guam: A Pilot Study, Water and Environmental Research Institute of the Western Pacific, Technical Report No. 87, University of Guam, Mangilao, Guam.

28. Eisler, R. and Hennekey, R. J., 1977. Acute toxicities of $\mathrm{Cd}^{2+}, \mathrm{Cr}^{6+}, \mathrm{Hg}^{2+}$, $\mathrm{Ni}^{2+}$, and $\mathrm{Zn}^{2+}$ to estuarine macrofauna. Arch. Environm. Contam. Toxicol. 6, $315-323$.

29. ESC-SOP-ICPOES-01. Standard Operational Procedue for the Determination of Minerals and Heavy Metals in Soil and Sediment Samples by ICP-AES. Environmental Studies Centre. Qatar University.

30. Feng, H., Han, X.F., Zhang, W.G., Yu, L.Z., 2004. A preliminary study of heavy metal contamination in Yangtze River intertidal zone due to urbanization. Marine. Pollution. Bulletin 49, 910-915.

31. Fergusson, J.E., 1990. The Heavy Elements: Chemistry, Environmental Impact and Health Effects, Pergamon Press, Oxford, England.

32. Finkelman, R.B., 2005. Sources and Health Effects of Metals and Trace Elements in our Environment: An Overview in T.A. Moore, A. Black, J.A. 
Centeno, J.S. Harding, D. A. Trumm (ed.), Metal Contaminants in New Zealand, Resolutionz Press, Christchurch, New Zealand, 25-46.

33. Forstner, U. and Wittman, G.T., 1983. Metal Pollution in the Aquatic Environment, Springer Verlag, Berlin, Heidelberg, 486.

34. Goldberg, E., 1992. Marine metal pollutants: a small set. Marine. Pollution. Bulletin 25, 45-47.

35. Guerra-Garcia, J.M. and Garcia-Gomez, J.C., 2005. Assessing pollution levels in sediments of a harbour with two opposing entrances. Environmental implications. J. Environ. Manage 77, 1-11.

36. Guevara R, Rizzo A, Sanchez R., 2005. Heavy metal inputs in northern Patagonia lakes from short sediment core analysis. J Radioanal Nucl. Chem. $265,481-493$

37. Güven, D.E. and Akıncı G., 2008. Heavy metals partitioning in the sediments of Izmir Inner Bay. J. Environ. Sci-China 20, 413-418.

38. Hatje, V., Payne, T.E., Hill, D.M., McOrist, G., Birch, G.F., Szymczak, R., 2003. Kinetics of trace element uptake and release by particles in estuarine waters: effects of pH, salinity, and particle loading. Environ. Int. 29, 619-629.

39. Hester, R.E. and Harisson, R.M., 2000. Chemistry in the Marine Environment. The Royal Society of Chemistry, Cambridge, UK

40. Honeyman, B.D. and Santschi, P.H., 1988. Metals in aquatic systems. Environ. Sci. Technol. 22, 862-871. 
41. Howari, F.M., 2005. Distribution of Heavy Metal Concentrations in Surface Sediments in Dubai Creeks, United Arab Emirates. Annali di Chimica 95.

42. Huh, C.A., Finey, B.P., Stull, J.K., 1992. Anthropogenic inputs of several heavy metals to nearshore basins off Los Angeles. Prog. Oceanogr. 30, 33551.

43. Irabien M J, Velasco F., 1999. Heavy metals in Oka Rivesediments (Urdaibai National Biosphere Reserve, Northern Spain): Lithogenic and anthropogenic effects. Environ Geol. 37, 54-63.

44. Kabata-Pendias, A. and Pendias, H., 2000. Trace Elements in Soil and Plants. (third ed.), CRC Press, Boca Raton, FL.

45. Krumgalz, B.S., Fainshtein, G., Cohen, A., 1992. Grain size effect on anthropogenic trace metals and organic matter distribution in marine sediments, The Science of the Total Environment, Elsevier Science Publishers $116,15-30$.

46. Langston, W.J., 2000. Toxic Effects of Metals and the Incidence of Metal Pollution in Marine Ecosystems, in R. W. Furness \& P. S. Rainbow (ed.), Heavy Metals in the Marine Environment, Florida, USA, 101-122.

47. Long, E.R., McDonald, D., Smith, S.L., Calder, F.D., 1995. Incidence of adverse biological effects within ranges of chemical concentrations in marine and estuarine sediments. Environ. Manage 19, 81-97. 
48. Loomb, C.A.M., 2001. Muddy Sedimentation in a Sheltered Estuarine Marine, Westpark Marina, Auckland, New Zealand, Thesis, The University of Waikato.

49. Luoma, S.N., 2000. Processes Affecting Metal Concentrations in Estuarine and Coastal Marine Sediments, in R. W. Furness \& P. S. Rainbow (ed.), Heavy Metals in the Marine Environment, CRC Press, Inc, Florida, USA, 5166.

50. Malins, D.C., 1984. Chemical pollutants in sediments and diseases of bottomdwelling fish in Puget Sound, Washington. Environ. Sci. Technol. 18,705713.

51. Mance, G., 1987. Pollution Threat of Heavy Metals in Aquatic Environments, Elsevier Applied Science Publishers Ltd, New York, USA.

52. Manheim, F.T., 1961, A geochemical profile in the Baltic Sea Geochimica et Cosmochimica Acta. 24,52-70.

53. Matthai, C., Birch, G.F., Bickford, G.P., 2002. Anthropogenic trace metals in sediment and settling particulate matter on a high energy continental shelf. Mar. Environ. Res. 54, 99-127.

54. Miller, B.S., Pirie, D., Redshaw, C.J., 2000. An Assessment of the Contamination and Toxicity of Marine Sediments in the Holy Loch, Scotland. Marine. Pollution. Bulletin 40,22-35. 
55. Muhammad Sadiq., 2002. Metal contamination in sediments from a desalination plant effluent outfall area. Science of The Total Environment $287,37-44$.

56. NAS, 1973. Medical and biological effects of environmental pollutants: manganese. Washington, DC, National Academy of Sciences, National Academy Press.

57. Olesik, J.W., 1996. Fundamental Research in ICP-OES and ICPMS. Anal. Chem. 68,469-474.

58. Pempkowiak, J., Sikora, A., Biernacka, E., 1999. Speciation of heavy metals in marine sediments vs their bioaccumulation by mussels. Chemosphere 39, 313-321.

59. Plant, J.A., Kinniburgh, D.G., Smedley, P.L., Fordyce, F.M., Klinck, B.A., 2003. Arsenic and Selenium, in H. D. Holland \& K. K. Turekian (ed.), Treatise on Geochemistry 9, 17-66.

60. Puyate, Y.T., Rim-Rukeh A., Awatefe, J.K., 2007. Metal Pollution Assessment and Particle Size Distribution of Bottom Sediment of Orogodo River, Agbor, Delta State, Nigeria. J. Appl. Sci. Res. 3, 2056-2061.

61. Redfern, F.M., 2006. Heavy Metal Contamination from Landfills in Coastal Marine Sediments: Kiribati and New Zealand, Thesis, The University of Waikato. 
62. Rope, S.K., Arthur, W.J., Craig, T.H., Craig, E.H., 1988. Nutrient and trace elements in soil and desert vegetation of southern Idaho. Environ. Monit. Assess. 10, 1-24.

63. Roth, L. and Hornung, H., 1977. Heavy metal concentration in water, sediments and fish from Mediterranean coastal area, Israel. Environmental Science Technology 11, 265-269.

64. Schlinder, P.W., 1991. The regulation of heavy metal concentrations in natural aquatic systems. In Heavy Metals in the Environment 1. (Ed) Vernet, J-P. Elsevier, Amsterdam, London, New York and Tokyo, 95-124.

65. Secrieru, Dan and Secrieru, Adraina, 2002. Heavy Metal Enrichment of Manmade Origin of Superficial Sediment on the Continental Shelf of the Northwestern Black Sea. Estuarine, Coastal and Shelf Science.54(3): 513-526.

66. Shiber, J. G. 1980. Deep Sea Research Part B. Oceanographic Literature Review. Soil Pollution 27, 860.

67. Shriadah, M. M. A., 1999.Heavy metals in mangrove sediments of the United Arab Emirates Shoreline (Arabian Gulf).Water, Air and Soil Pollution 116, 523-534.

68. Topcuoglu, S., Kirbasoglu, C., Gungor, N., 2002. Heavy metals in organisms and sediments from Turkish coast of the Black Sea, 1997-1998. Environ. Int. $27,521-526$. 
69. USEPA, 1998. EPA's Contaminated Sediment Management Strategy. 823-R$98-001$.

70. USEPA 3051A, Acid Digestion of Sediments, sludges and Soils for acid extractable/total recoverable metals.

71. Valentukevičienė M. and Brannvall E., 2008. Marine pollution: an overview. Geologija. Vilnius 1, 17-23.

72. Vernet, J.P. (ed), 1991. Heavy Metals in the Environment. Elsevier Science Publishers B.V, New York, USA.

73. Wang, X.C., Feng, H., Ma, H.Q., 2007. Assessment of Metal Contamination in Surface Sediments of Jiaozhou Bay, Qingdao, China. Clean 35, 62-70.

74. Wang F, Chen J S., 2000. Relation of sediment characteristics to trace metal concentration: a statistical study. Wat. Res.34, 694-698.

75. WHO, 1981. Environmental health criteria 17: Manganese. Geneva, World Health Organization.

76. Williamson, B., Lewis, G., Mills, G., Vant, B., 2003. Contaminants on the coast, in J. R. Goff, S. L. Nichol \& H. L. Rouse (ed.), The New Zealand Coast: Te Tai o Aotearoa, Dunmore Press, Palmerston North, New Zealand, $237-259$.

77. Williamson, R.B. and Wilcock, R.J., 1994, The Distribution and Fate of Contaminants in Estuarine Sediments: Recommendations for environmental monitoring and assessment, Technical Publication, 47, New Zealand. 
78. Windholz, M., 1983. The Merck index: An encyclopedia of chemicals, drugs and biologicals, 10th ed. Rahway, NJ, Merck and Company, Inc. 816-818.

79. Wood, J.M. and Wang, H.K., 1983. Microbial resistance to heavy metals. Environ. Sci. Technol. 17,582A-590A.

80. Wood, J.M., 1974. Biological cycles for toxic elements in the environment. Science183, 10 . 


\section{Appendix A : Results of Metal Analyses}

Table 1: Metals concentrations recorded in sediment samples collected from Doha Bay during May, 2012, (Phase I)

\begin{tabular}{|c|c|c|c|c|c|c|c|c|c|c|}
\hline \multirow{2}{*}{ Station } & \multicolumn{10}{|c|}{ Concentration (ppm) } \\
\hline & Al & As & Ва & $\mathrm{Be}$ & Cd & Co & $\mathrm{Cr}$ & $\mathrm{Cu}$ & $\mathrm{Fe}$ & K \\
\hline A1 & 2082.06 & $<\mathrm{LOQ}$ & 22.99 & $<L O Q$ & 0.27 & $<\mathrm{LOQ}$ & 5.50 & 0.94 & 917.11 & 1262.07 \\
\hline A2 & 1696.31 & $<\mathrm{LOQ}$ & 11.38 & $<L O Q$ & 0.20 & $<\mathrm{LOQ}$ & 3.34 & 0.99 & 590.78 & 1483.93 \\
\hline A3 & $<\mathrm{LOQ}$ & $<\mathrm{LOQ}$ & $<\mathrm{LOQ}$ & $<\mathrm{LOQ}$ & $<\mathrm{LOQ}$ & $<\mathrm{LOQ}$ & $<\mathrm{LOQ}$ & $<\mathrm{LOQ}$ & $<L O Q$ & $<\mathrm{LOQ}$ \\
\hline A4 & 1992.65 & $<\mathrm{LOQ}$ & 12.08 & $<\mathrm{LOQ}$ & 0.09 & $<\mathrm{LOQ}$ & 4.78 & 1.52 & 1038.30 & 1568.05 \\
\hline A5 & 1960.94 & $<\mathrm{LOQ}$ & 11.11 & $<\mathrm{LOQ}$ & 0.13 & $<\mathrm{LOQ}$ & 4.19 & 1.40 & 973.02 & 1609.27 \\
\hline B1 & 1035.57 & $<\mathrm{LOQ}$ & 9.14 & $<\mathrm{LOQ}$ & 0.05 & $<\mathrm{LOQ}$ & 2.88 & 1.75 & 395.01 & 1230.76 \\
\hline B2 & 840.50 & $<\mathrm{LOQ}$ & 8.52 & $<\mathrm{LOQ}$ & $<\mathrm{LOQ}$ & $<\mathrm{LOQ}$ & 2.12 & 1.45 & 413.81 & 1126.19 \\
\hline B3 & 1704.26 & $<\mathrm{LOQ}$ & 10.47 & $<\mathrm{LOQ}$ & 0.19 & $<\mathrm{LOQ}$ & 2.98 & 0.87 & 595.95 & 1452.14 \\
\hline B4 & 2041.19 & $<\mathrm{LOQ}$ & 11.68 & $<L O Q$ & 0.18 & $<L O Q$ & 3.99 & 1.68 & 899.31 & 1620.32 \\
\hline B5 & 805.96 & $<L O Q$ & 8.00 & $<L O Q$ & 0.13 & $<L O Q$ & 0.74 & 0.38 & 146.42 & 1077.43 \\
\hline C1 & 987.33 & $<L O Q$ & 21.94 & $<L O Q$ & 0.11 & 0.21 & 3.98 & 0.21 & 443.65 & 694.66 \\
\hline C2 & 675.27 & $<\mathrm{LOQ}$ & $<\mathrm{LOQ}$ & $<\mathrm{LOQ}$ & 0.10 & $<\mathrm{LOQ}$ & 1.86 & 0.92 & 294.19 & 2180.78 \\
\hline C3 & 2134.09 & $<\mathrm{LOQ}$ & 11.78 & $<\mathrm{LOQ}$ & 0.13 & $<\mathrm{LOQ}$ & 4.44 & 1.60 & 922.82 & 1698.20 \\
\hline C4 & 2729.22 & 1.24 & 13.74 & 0.05 & $<L O Q$ & 0.60 & 6.89 & 2.34 & 1617.27 & 1757.14 \\
\hline C5 & 507.03 & $<L O Q$ & 6.87 & 0.01 & $<\mathrm{LOQ}$ & 0.18 & 1.97 & 0.51 & 296.60 & 990.42 \\
\hline D1 & 1845.91 & $<\mathrm{LOQ}$ & 14.27 & $<\mathrm{LOQ}$ & 0.24 & $<\mathrm{LOQ}$ & 2.99 & 0.94 & 422.96 & 1583.16 \\
\hline D2 & 1687.89 & $<\mathrm{LOQ}$ & 2.55 & $<\mathrm{LOQ}$ & 0.12 & $<\mathrm{LOQ}$ & 4.62 & 1.15 & 936.46 & 2233.47 \\
\hline D3 & 3549.50 & $<L O Q$ & 20.25 & $<L O Q$ & 0.13 & 0.39 & 8.77 & 3.15 & 1984.75 & 2082.51 \\
\hline D4 & 2540.08 & $<\angle O Q$ & 41.55 & $<\mathrm{LOQ}$ & 0.07 & 0.32 & 7.24 & 2.54 & 1423.64 & 1788.92 \\
\hline D5 & 1013.83 & $<L O Q$ & 8.19 & $<L O Q$ & 0.05 & $<\mathrm{LOQ}$ & 2.47 & 1.23 & 432.94 & 1227.87 \\
\hline E1 & 3840.12 & $<L O Q$ & 26.10 & 0.03 & 0.08 & 0.46 & 10.23 & 3.04 & 1976.08 & 2187.62 \\
\hline E2 & 3657.62 & $<\angle O Q$ & 18.63 & $<\mathrm{LOQ}$ & 0.14 & 0.32 & 9.06 & 3.41 & 1934.93 & 2197.99 \\
\hline E3 & 4580.24 & $<\mathrm{LOQ}$ & 23.00 & $<\mathrm{LOQ}$ & 0.19 & 0.42 & 10.83 & 3.87 & 2392.97 & 2500.38 \\
\hline E4 & 3143.47 & $<L O Q$ & 19.50 & 0.05 & $<\mathrm{LOQ}$ & 0.86 & 9.98 & 3.56 & 2119.83 & 1794.12 \\
\hline E5 & 3389.25 & $<\mathrm{LOQ}$ & 37.83 & $<\mathrm{LOQ}$ & 0.21 & $<L O Q$ & 7.47 & 3.63 & 1680.00 & 1963.82 \\
\hline
\end{tabular}


Cont. Table 1:

\begin{tabular}{|c|c|c|c|c|c|c|c|c|c|c|}
\hline \multirow{2}{*}{ Station } & \multicolumn{10}{|c|}{ Concentration (ppm) } \\
\hline & Al & As & $\mathrm{Ba}$ & $\mathrm{Be}$ & Cd & Co & $\mathrm{Cr}$ & $\mathrm{Cu}$ & $\mathrm{Fe}$ & K \\
\hline F1 & 3734.04 & $<\mathrm{LOQ}$ & 39.01 & $<L O Q$ & 0.13 & 0.85 & 12.74 & 3.75 & 2472.13 & 1721.94 \\
\hline F2 & 2352.00 & $<L O Q$ & 23.56 & $<\mathrm{LOQ}$ & 0.10 & 0.53 & 8.11 & 2.31 & 1584.10 & 1077.55 \\
\hline F3 & 3515.87 & $<L O Q$ & 16.47 & 0.06 & $<L O Q$ & 0.75 & 9.91 & 3.78 & 2270.12 & 2003.82 \\
\hline F4 & 1822.43 & $<L O Q$ & 11.76 & $<L O Q$ & 0.15 & $<\mathrm{LOQ}$ & 4.28 & 2.04 & 629.32 & 1588.63 \\
\hline F5 & 3527.43 & $<L O Q$ & 29.78 & $<L O Q$ & $<L O Q$ & 0.66 & 11.27 & 2.24 & 2330.17 & 2016.89 \\
\hline G1 & 2205.12 & $<L O Q$ & 13.14 & $<L O Q$ & 0.13 & $<\mathrm{LOQ}$ & 4.83 & 1.70 & 1080.12 & 1679.76 \\
\hline G2 & 1008.44 & $<\angle O Q$ & 7.48 & $<\angle O Q$ & 0.05 & $<\mathrm{LOQ}$ & 2.84 & 0.49 & 379.86 & 1204.62 \\
\hline G3 & 3424.82 & $<\angle O Q$ & 14.48 & 0.06 & $<\angle O Q$ & 1.08 & 10.55 & 4.95 & 2336.50 & 2504.19 \\
\hline G4 & 3925.08 & 0.99 & 24.83 & 0.01 & 0.12 & 0.51 & 9.70 & 4.68 & 2305.29 & 2145.52 \\
\hline G5 & 3036.48 & $<L O Q$ & 23.70 & $<\angle O Q$ & 0.11 & 0.62 & 9.01 & 2.58 & 2114.56 & 1482.13 \\
\hline H1 & 4812.30 & $<\angle O Q$ & 29.06 & 0.05 & 0.07 & 1.09 & 14.83 & 6.40 & 3233.51 & 2646.76 \\
\hline $\mathrm{H} 2$ & 4228.24 & $<\angle O Q$ & 26.28 & 0.06 & $<\angle O Q$ & 0.57 & 10.08 & 3.90 & 2061.58 & 2403.23 \\
\hline $\mathrm{H3}$ & 1899.32 & $<\angle O Q$ & 12.64 & $<L O Q$ & 0.12 & $<\mathrm{LOQ}$ & 3.88 & 1.39 & 735.13 & 1565.40 \\
\hline $\mathrm{H} 4$ & 2114.14 & 2.92 & 12.24 & $<\angle O Q$ & 0.11 & 0.19 & 5.38 & 2.39 & 1432.26 & 1524.37 \\
\hline H5 & 2269.59 & 2.18 & 14.10 & 0.05 & $<\mathrm{LOQ}$ & 0.72 & 6.66 & 3.18 & 2046.53 & 1593.67 \\
\hline I1 & 3786.41 & $<L O Q$ & 31.29 & 0.05 & $<L O Q$ & 0.75 & 11.06 & 5.90 & 2477.23 & 2094.33 \\
\hline 12 & 2750.55 & $<\angle O Q$ & 15.42 & 0.01 & 0.11 & LOQ & 6.53 & 3.83 & 1331.94 & 1851.46 \\
\hline 13 & 3577.47 & $<\angle O Q$ & 23.89 & $<\angle O Q$ & 0.09 & 0.36 & 8.54 & 3.87 & 1930.92 & 2149.29 \\
\hline 14 & 2414.79 & $<\mathrm{LOQ}$ & 18.34 & $<\mathrm{LOQ}$ & 0.12 & $<\mathrm{LOQ}$ & 3.83 & 1.37 & 808.81 & 1930.04 \\
\hline 15 & 3540.04 & $<\angle O Q$ & 26.64 & 0.02 & 0.08 & 0.61 & 9.17 & 4.98 & 2221.48 & 2040.78 \\
\hline J1 & 1937.44 & 1.05 & 24.25 & $<L O Q$ & 0.08 & $<\mathrm{LOQ}$ & 5.11 & 6.23 & 1201.46 & 1535.03 \\
\hline J2 & 3275.89 & 1.86 & 20.81 & 0.10 & $<\angle O Q$ & 0.87 & 9.75 & 5.87 & 2289.76 & 1875.07 \\
\hline J3 & 2524.05 & $<\angle O Q$ & 14.80 & $<\mathrm{LOQ}$ & 0.10 & $<\mathrm{LOQ}$ & 6.12 & 3.70 & 1312.73 & 1694.00 \\
\hline J4 & 3510.31 & 2.15 & 22.10 & 0.03 & 0.08 & 0.68 & 9.47 & 5.08 & 2269.09 & 2037.78 \\
\hline $\mathrm{J5}$ & 2591.39 & $<\mathrm{LOQ}$ & 13.85 & $<\mathrm{LOQ}$ & 0.21 & $<\mathrm{LOQ}$ & 5.45 & 2.42 & 1228.48 & 1784.01 \\
\hline Min & 507.03 & $<\mathrm{LOQ}$ & $<$ LOQ & $<L O Q$ & $<\mathrm{LOQ}$ & $<\mathrm{LOQ}$ & $<\mathrm{LOQ}$ & $<\mathrm{LOQ}$ & $<$ LOQ & $<$ LOQ \\
\hline Max & 4812.30 & 2.92 & 41.55 & 0.10 & 0.27 & 1.09 & 14.83 & 6.40 & 3233.51 & 2646.76 \\
\hline Average & 2535.18 & $\sim$ & 18.36 & $\sim$ & 0.13 & $\sim$ & 6.58 & 2.70 & 1406.77 & 1744.11 \\
\hline SD & 1091.18 & $\sim$ & 8.79 & $\sim$ & 0.05 & $\sim$ & 3.32 & 1.66 & 783.06 & 426.07 \\
\hline
\end{tabular}


Cont. Table 1:

\begin{tabular}{|c|c|c|c|c|c|c|c|c|c|c|}
\hline \multirow{2}{*}{ Station } & \multicolumn{10}{|c|}{ Concentration (ppm) } \\
\hline & Li & Mg & $M n$ & Mo & $\mathrm{Ni}$ & $\mathrm{Pb}$ & Sb & $\mathbf{v}$ & $\mathrm{Zn}$ & $\mathrm{Hg}$ \\
\hline A1 & 3.32 & 7964.32 & 15.82 & $<L O Q$ & 2.45 & $<L O Q$ & 1.54 & 4.61 & 6.16 & 0.004 \\
\hline A2 & 2.49 & 4838.07 & 8.12 & $<\mathrm{LOQ}$ & 1.62 & $<\mathrm{LOQ}$ & 0.47 & 3.24 & 2.89 & 0.005 \\
\hline A3 & $<\mathrm{LOQ}$ & $<\mathrm{LOQ}$ & $<L O Q$ & $<L O Q$ & $<L O Q$ & $<L O Q$ & $<\mathrm{LOQ}$ & $<L O Q$ & $<\mathrm{LOQ}$ & 0.003 \\
\hline A4 & 2.43 & 4885.73 & 19.20 & $<L O Q$ & 3.16 & $<\mathrm{LOQ}$ & $<\mathrm{LOQ}$ & 3.88 & 3.74 & 0.003 \\
\hline A5 & 2.64 & 5621.10 & 15.18 & $<L O Q$ & 2.69 & $<L O Q$ & 0.30 & 3.70 & 4.12 & 0.005 \\
\hline B1 & 2.04 & 6231.78 & 8.25 & $<L O Q$ & 1.36 & $<L O Q$ & 0.05 & 2.74 & 2.85 & 0.003 \\
\hline B2 & 1.92 & 5396.17 & 7.13 & $<L O Q$ & 1.21 & $<L O Q$ & 0.47 & 2.33 & 3.26 & 0.003 \\
\hline B3 & 2.58 & 5321.34 & 8.76 & $<L O Q$ & 1.33 & $<L O Q$ & 0.65 & 3.10 & 3.21 & 0.003 \\
\hline B4 & 2.61 & 6541.03 & 14.08 & $<L O Q$ & 2.48 & $<\mathrm{LOQ}$ & 0.26 & 3.70 & 4.32 & 0.004 \\
\hline B5 & 2.11 & 8896.70 & 5.02 & $<L O Q$ & 0.28 & $<L O Q$ & 0.23 & 1.18 & 2.47 & 0.003 \\
\hline C1 & 2.52 & 6225.89 & 9.72 & $<L O Q$ & 1.53 & $<L O Q$ & 1.47 & 2.88 & 5.82 & 0.004 \\
\hline C2 & 1.23 & 4074.62 & 4.18 & $<L O Q$ & 1.24 & $<L O Q$ & 0.08 & 1.52 & 2.71 & 0.005 \\
\hline C3 & 2.39 & 7528.11 & 16.18 & $<L O Q$ & 2.96 & $<L O Q$ & 0.21 & 3.81 & 4.50 & 0.006 \\
\hline C4 & 2.82 & 8014.49 & 26.03 & $<\mathrm{LOQ}$ & 4.72 & $<\mathrm{LOQ}$ & 0.23 & 5.97 & 5.79 & 0.003 \\
\hline C5 & 1.67 & 4474.10 & 5.09 & $<\mathrm{LOQ}$ & 1.06 & $<L O Q$ & 0.35 & 2.02 & 4.26 & 0.001 \\
\hline D1 & 2.42 & 5406.63 & 7.96 & $<L O Q$ & 1.07 & $<L O Q$ & 0.62 & 2.66 & 2.54 & 0.002 \\
\hline D2 & 1.79 & 5505.43 & 13.90 & $<\mathrm{LOQ}$ & 2.88 & $<\mathrm{LOQ}$ & 0.26 & 3.75 & 4.81 & 0.006 \\
\hline D3 & 3.54 & 9826.84 & 31.54 & $<L O Q$ & 6.17 & $<L O Q$ & 0.07 & 7.72 & 6.59 & 0.007 \\
\hline D4 & 2.48 & 9863.51 & 23.12 & $<\mathrm{LOQ}$ & 4.26 & $<\mathrm{LOQ}$ & 0.93 & 6.29 & 7.34 & 0.005 \\
\hline D5 & 2.11 & 6011.28 & 7.22 & $<L O Q$ & 1.44 & $<L O Q$ & LOQ & 2.75 & 3.89 & 0.003 \\
\hline E1 & 3.63 & 11530.63 & 39.49 & $<\mathrm{LOQ}$ & 5.17 & $<L O Q$ & 0.09 & 8.68 & 8.11 & 0.003 \\
\hline E2 & 3.65 & 8654.37 & 32.83 & $<L O Q$ & 5.33 & $<L O Q$ & 0.47 & 8.30 & 7.77 & 0.005 \\
\hline E3 & 4.16 & 9077.97 & 43.14 & $<L O Q$ & 6.94 & $<L O Q$ & 0.32 & 9.30 & 8.47 & 0.008 \\
\hline E4 & 3.20 & 9576.05 & 35.14 & $<\mathrm{LOQ}$ & 6.59 & $<\mathrm{LOQ}$ & $<\mathrm{LOQ}$ & 8.51 & 7.49 & 0.007 \\
\hline E5 & 3.97 & 19413.22 & 31.60 & $<\mathrm{LOQ}$ & 4.41 & $<\mathrm{LOQ}$ & 0.32 & 9.09 & 5.80 & 0.005 \\
\hline
\end{tabular}


Cont. Table 1:

\begin{tabular}{|c|c|c|c|c|c|c|c|c|c|c|}
\hline \multirow{2}{*}{ Station } & \multicolumn{10}{|c|}{ Concentration (ppm) } \\
\hline & Li & Mg & $\mathrm{Mn}$ & Mo & $\mathrm{Ni}$ & $\mathrm{Pb}$ & Sb & v & $\mathrm{Zn}$ & $\mathrm{Hg}$ \\
\hline F1 & 4.51 & 13061.93 & 37.42 & $<\mathrm{LOQ}$ & 7.06 & $<L O Q$ & 1.02 & 10.37 & 10.26 & 0.005 \\
\hline F2 & 3.62 & 6805.95 & 22.73 & $<\mathrm{LOQ}$ & 4.62 & $<\mathrm{LOQ}$ & 1.74 & 6.59 & 10.29 & 0.007 \\
\hline F3 & 3.47 & 8825.67 & 35.26 & $<\mathrm{LOQ}$ & 7.09 & $<L O Q$ & 0.13 & 8.56 & 7.94 & 0.008 \\
\hline F4 & 2.56 & 6713.23 & 11.68 & $<\mathrm{LOQ}$ & 1.78 & $<L O Q$ & 0.52 & 3.17 & 4.55 & 0.005 \\
\hline F5 & 4.24 & 47139.99 & 53.22 & $<\mathrm{LOQ}$ & 5.49 & $<L O Q$ & 0.98 & 13.21 & 8.86 & 0.005 \\
\hline G1 & 2.77 & 6262.54 & 17.16 & $<\mathrm{LOQ}$ & 2.61 & $<L O Q$ & 0.25 & 5.10 & 4.95 & 0.006 \\
\hline G2 & 2.31 & 7782.47 & 8.02 & $<\mathrm{LOQ}$ & 0.78 & $<\mathrm{LOQ}$ & 0.27 & 2.36 & 4.10 & 0.004 \\
\hline G3 & 3.02 & 8794.42 & 35.07 & $<\mathrm{LOQ}$ & 7.67 & $<\mathrm{LOQ}$ & 0.06 & 8.76 & 9.83 & 0.010 \\
\hline G4 & 3.83 & 8923.90 & 34.40 & $<\mathrm{LOQ}$ & 7.09 & $<\mathrm{LOQ}$ & 0.24 & 8.68 & 8.05 & 0.013 \\
\hline G5 & 4.34 & 21145.72 & 36.05 & $<\mathrm{LOQ}$ & 5.34 & $<\mathrm{LOQ}$ & 1.18 & 9.85 & 9.74 & 0.005 \\
\hline H1 & 4.71 & 23414.91 & 41.46 & $<\mathrm{LOQ}$ & 7.69 & $<L O Q$ & 0.38 & 18.17 & 14.83 & 0.007 \\
\hline $\mathrm{H} 2$ & 3.67 & 10201.44 & 37.16 & $<\mathrm{LOQ}$ & 5.77 & $<L O Q$ & 0.12 & 8.35 & 8.29 & 0.037 \\
\hline H3 & 2.56 & 5237.53 & 11.55 & $<\mathrm{LOQ}$ & 1.81 & $<\mathrm{LOQ}$ & 0.22 & 3.36 & 3.87 & 0.006 \\
\hline H4 & 2.63 & 5782.55 & 17.66 & $<\mathrm{LOQ}$ & 3.08 & $<\mathrm{LOQ}$ & 0.17 & 7.26 & 5.89 & 0.006 \\
\hline H5 & 2.84 & 8142.71 & 30.30 & $<\mathrm{LOQ}$ & 4.59 & $<\mathrm{LOQ}$ & 0.16 & 8.29 & 8.78 & 0.008 \\
\hline II & 3.84 & 9601.71 & 33.96 & $<\mathrm{LOQ}$ & 7.37 & $<L O Q$ & 0.19 & 10.20 & 10.83 & 0.005 \\
\hline 12 & 2.99 & 6994.04 & 20.00 & $<\mathrm{LOQ}$ & 3.96 & $<\mathrm{LOQ}$ & 0.43 & 5.56 & 7.77 & 0.005 \\
\hline 13 & 3.69 & 8918.62 & 31.69 & $<\mathrm{LOQ}$ & 5.48 & $<L O Q$ & 0.39 & 8.31 & 8.90 & 0.009 \\
\hline 14 & 2.43 & 4399.64 & 15.04 & $<\mathrm{LOQ}$ & 1.77 & $<\mathrm{LOQ}$ & $<\mathrm{LOQ}$ & 3.29 & 3.75 & 0.006 \\
\hline 15 & 3.89 & 10179.98 & 34.22 & $<\mathrm{LOQ}$ & 6.43 & $<L O Q$ & 0.00 & 9.27 & 9.24 & 0.008 \\
\hline J1 & 2.64 & 6795.02 & 16.60 & $<\mathrm{LOQ}$ & 2.78 & $<\mathrm{LOQ}$ & $<\mathrm{LOQ}$ & 5.61 & 8.01 & 0.008 \\
\hline J2 & 3.57 & 10603.29 & 33.95 & $<\mathrm{LOQ}$ & 7.27 & $<L O Q$ & 0.01 & 8.42 & 9.09 & 0.010 \\
\hline J3 & 3.02 & 7152.67 & 19.77 & $<\mathrm{LOQ}$ & 4.05 & $<\mathrm{LOQ}$ & $<\mathrm{LOQ}$ & 5.47 & 6.00 & 0.007 \\
\hline J4 & 3.68 & 9792.36 & 31.94 & $<\mathrm{LOQ}$ & 7.18 & $<L O Q$ & $<\mathrm{LOQ}$ & 8.54 & 8.71 & 0.009 \\
\hline J5 & 3.24 & 9051.08 & 17.35 & $<\mathrm{LOQ}$ & 3.26 & $<\mathrm{LOQ}$ & 0.26 & 5.62 & 6.43 & 0.008 \\
\hline Min & $<$ LOQ & $<L O Q$ & $<\mathrm{LOQ}$ & $<$ LOQ & $<\mathrm{LOQ}$ & $<\mathrm{LOQ}$ & 0.00 & $<\mathrm{LOQ}$ & $<L O Q$ & 0.00 \\
\hline Max & 4.71 & 47139.99 & 53.22 & $<$ LOQ & 7.69 & $<$ LOQ & 1.74 & 18.17 & 14.83 & 0.04 \\
\hline Average & 3.02 & 9236.79 & 22.70 & $\sim$ & 3.97 & $\sim$ & 0.42 & 6.21 & 6.49 & 0.01 \\
\hline SD & 0.80 & 6771.98 & 12.49 & $\sim$ & 2.26 & $\sim$ & 0.42 & 3.38 & 2.72 & 0.00 \\
\hline
\end{tabular}


Table 2: Metal concentration recorded in sediment samples collected from Doha Bay during December, 2012 (Phase II)

\begin{tabular}{|c|c|c|c|c|c|c|c|c|c|c|}
\hline \multirow{2}{*}{ Station } & \multicolumn{10}{|c|}{ Concentration (ppm) } \\
\hline & Al & As & $\mathrm{Ba}$ & $\mathrm{Be}$ & $\mathrm{Cd}$ & Co & $\mathrm{Cr}$ & $\mathrm{Cu}$ & $\mathrm{Fe}$ & K \\
\hline A1 & 3477.75 & 1.93 & 14.67 & $<L O Q$ & 0.39 & $<L O Q$ & 6.57 & 1.31 & 841.95 & 2781.53 \\
\hline A2 & 3678.43 & 0.94 & 54.54 & $<L O Q$ & 0.36 & $<L O Q$ & 5.14 & 1.29 & 657.76 & 2040.15 \\
\hline A3 & 3502.93 & 1.86 & 23.19 & $<L O Q$ & 0.32 & $<L O Q$ & 4.21 & 1.95 & 744.69 & 1895.03 \\
\hline A4 & 3709.50 & 1.83 & 23.94 & $<\mathrm{LOQ}$ & 0.33 & $<L O Q$ & 4.93 & 2.15 & 900.16 & 1967.79 \\
\hline A5 & 4367.08 & 1.93 & 28.25 & $<L O Q$ & 0.46 & $<L O Q$ & 6.02 & 2.55 & 1098.91 & 2132.56 \\
\hline B1 & 3400.24 & 1.72 & 25.94 & $<L O Q$ & 0.39 & $<\mathrm{LOQ}$ & 3.58 & 1.62 & 442.20 & 1910.13 \\
\hline B2 & 3875.90 & 2.56 & 28.19 & $<L O Q$ & 0.43 & $<\mathrm{LOQ}$ & 3.39 & 1.86 & 444.67 & 2057.24 \\
\hline B3 & 3330.97 & 1.64 & 36.09 & $<L O Q$ & 0.44 & $<L O Q$ & 4.33 & 1.04 & 619.58 & 1291.07 \\
\hline B4 & 2853.36 & 1.29 & 22.25 & $<L O Q$ & 0.36 & $<\mathrm{LOQ}$ & 0.68 & 1.08 & 123.04 & 1703.75 \\
\hline B5 & 2722.50 & 0.99 & 35.72 & $<L O Q$ & 0.48 & $<\mathrm{LOQ}$ & 1.57 & 0.52 & 138.38 & 1104.24 \\
\hline C1 & 3808.70 & 1.86 & 30.16 & $<L O Q$ & 0.39 & $<\mathrm{LOQ}$ & 3.99 & 1.67 & 461.21 & 2048.42 \\
\hline C2 & 3221.65 & 1.52 & 25.19 & $<L O Q$ & 0.39 & $<L O Q$ & 1.59 & 1.50 & 250.84 & 1786.44 \\
\hline C3 & 3844.70 & 0.94 & 24.51 & $<L O Q$ & 0.38 & $<\mathrm{LOQ}$ & 4.88 & 2.05 & 859.29 & 2003.30 \\
\hline C4 & 3489.49 & 2.14 & 24.17 & $<L O Q$ & 0.36 & $<L O Q$ & 4.83 & 2.12 & 756.13 & 1939.34 \\
\hline C5 & 2130.38 & 1.07 & 19.03 & $<L O Q$ & 0.24 & $<L O Q$ & 2.74 & 1.32 & 331.41 & 1273.20 \\
\hline D1 & 2325.53 & $<\mathrm{LOQ}$ & 19.14 & $<\mathrm{LOQ}$ & 0.24 & $<\mathrm{LOQ}$ & 3.13 & 2.37 & 450.19 & 1344.53 \\
\hline D2 & 4485.85 & 2.25 & 26.76 & 0.01 & 0.38 & $<L O Q$ & 7.15 & 2.85 & 1380.87 & 2190.28 \\
\hline D3 & 4298.22 & 1.13 & 32.51 & 0.03 & 0.25 & 0.34 & 9.78 & 3.61 & 1882.03 & 1652.96 \\
\hline D4 & 5057.71 & 1.58 & 70.74 & 0.03 & 0.29 & $<L O Q$ & 9.59 & 3.65 & 2044.23 & 2097.58 \\
\hline D5 & 2286.26 & $<\mathrm{LOQ}$ & 17.36 & $<L O Q$ & 0.23 & $<L O Q$ & 3.20 & 1.58 & 497.92 & 1200.40 \\
\hline E1 & 5640.99 & 1.17 & 33.27 & 0.05 & 0.36 & 0.23 & 11.30 & 4.83 & 2002.82 & 2447.15 \\
\hline E2 & 4916.56 & 1.36 & 30.30 & 0.03 & 0.38 & $<L O Q$ & 8.65 & 3.57 & 1623.82 & 2291.59 \\
\hline E3 & 6397.17 & 1.38 & 36.39 & 0.06 & 0.39 & 0.30 & 12.00 & 4.31 & 2368.46 & 2745.78 \\
\hline E4 & 4979.45 & 1.39 & 30.97 & 0.04 & 0.29 & $<L O Q$ & 9.74 & 3.56 & 1801.82 & 2247.39 \\
\hline E5 & 4937.60 & 1.34 & 51.03 & 0.04 & 0.31 & $<L O Q$ & 9.19 & 3.35 & 1661.77 & 2157.52 \\
\hline
\end{tabular}


Cont. Table 2:

\begin{tabular}{|c|c|c|c|c|c|c|c|c|c|c|}
\hline \multirow{2}{*}{ Station } & \multicolumn{10}{|c|}{ Concentration (ppm) } \\
\hline & Al & As & $\mathrm{Ba}$ & $\mathrm{Be}$ & $\mathrm{Cd}$ & Co & $\mathrm{Cr}$ & $\mathrm{Cu}$ & $\mathrm{Fe}$ & K \\
\hline F1 & 3897.40 & 0.93 & 25.01 & 0.02 & 0.22 & $<\mathrm{LOQ}$ & 7.26 & 1.73 & 857.43 & 2672.63 \\
\hline F2 & 3572.16 & 1.59 & 21.16 & $<L O Q$ & 0.25 & $<\mathrm{LOQ}$ & 7.82 & 3.72 & 1380.57 & 1667.80 \\
\hline F3 & 4527.86 & 1.20 & 25.63 & 0.04 & 0.21 & 0.34 & 10.02 & 4.72 & 2014.90 & 1994.49 \\
\hline F4 & 2428.02 & 1.15 & 19.21 & $<\mathrm{LOQ}$ & 0.23 & $<\mathrm{LOQ}$ & 5.69 & 2.70 & 561.14 & 1478.66 \\
\hline F5 & 4397.27 & $<\mathrm{LOQ}$ & 23.14 & 0.06 & 0.21 & 0.21 & 10.50 & 3.95 & 1985.17 & 1898.09 \\
\hline G1 & 3475.91 & 1.46 & 21.90 & $<\mathrm{LOQ}$ & 0.25 & $<\mathrm{LOQ}$ & 7.08 & 2.92 & 1256.65 & 1650.17 \\
\hline G2 & 2202.14 & 1.16 & 18.27 & $<\mathrm{LOQ}$ & 0.23 & $<\mathrm{LOQ}$ & 2.32 & 1.47 & 292.71 & 1316.11 \\
\hline G3 & 4753.38 & 1.67 & 29.87 & 0.05 & 0.18 & 0.61 & 11.13 & 6.10 & 2361.26 & 2113.11 \\
\hline G4 & 4871.09 & 1.12 & 31.27 & 0.06 & 0.19 & 0.42 & 11.09 & 5.77 & 2300.23 & 2014.36 \\
\hline G5 & 3408.47 & 2.20 & 15.54 & 0.02 & 0.21 & 0.24 & 7.76 & 2.74 & 1641.12 & 1979.62 \\
\hline H1 & 4255.40 & 1.39 & 31.36 & 0.06 & 0.11 & 0.43 & 11.63 & 5.44 & 2311.31 & 1647.13 \\
\hline H2 & 5589.96 & 1.68 & 40.70 & 0.06 & 0.23 & 0.40 & 12.29 & 5.98 & 2342.89 & 2484.98 \\
\hline H3 & 2899.22 & 1.43 & 20.84 & $<L O Q$ & 0.25 & $<\mathrm{LOQ}$ & 4.38 & 2.53 & 660.32 & 1532.62 \\
\hline H4 & 2832.11 & 1.55 & 34.06 & $<\mathrm{LOQ}$ & 0.24 & $<\mathrm{LOQ}$ & 6.44 & 3.21 & 1222.81 & 1532.09 \\
\hline H5 & 3995.00 & 4.21 & 27.47 & $<\mathrm{LOQ}$ & 0.31 & $<\mathrm{LOQ}$ & 7.50 & 4.45 & 1623.99 & 1885.39 \\
\hline I1 & 5346.41 & $<\mathrm{LOQ}$ & 35.03 & 0.04 & 0.40 & 0.27 & 10.07 & 3.79 & 1767.44 & 3050.33 \\
\hline 12 & 3628.05 & $<L O Q$ & 22.24 & 0.02 & 0.21 & $<\mathrm{LOQ}$ & 7.99 & 4.79 & 1368.90 & 1683.50 \\
\hline 13 & 4812.87 & $<L O Q$ & 31.97 & 0.03 & 0.21 & 0.30 & 9.96 & 5.57 & 2013.44 & 2071.83 \\
\hline 14 & 3578.94 & 0.94 & 36.22 & $<\mathrm{LOQ}$ & 0.24 & $<\mathrm{LOQ}$ & 5.76 & 2.77 & 1070.29 & 1674.31 \\
\hline 15 & 4583.49 & 0.97 & 34.81 & 0.03 & 0.23 & 0.41 & 10.49 & 5.12 & 2163.81 & 1888.85 \\
\hline J1 & 3326.99 & 3.22 & 40.28 & $<\mathrm{LOQ}$ & 0.28 & $<\mathrm{LOQ}$ & 7.18 & 6.87 & 1565.23 & 1576.02 \\
\hline J2 & 4194.59 & $<\mathrm{LOQ}$ & 41.50 & 0.02 & 0.25 & 0.22 & 9.28 & 5.32 & 1909.12 & 1890.13 \\
\hline J3 & 4844.96 & $<\mathrm{LOQ}$ & 40.12 & 0.03 & 0.39 & $<\mathrm{LOQ}$ & 9.68 & 4.55 & 1888.72 & 1764.44 \\
\hline J4 & 4390.46 & 1.10 & 29.38 & 0.04 & 0.21 & 0.36 & 9.83 & 5.04 & 2082.71 & 1801.80 \\
\hline J5 & 2975.18 & 1.20 & 20.62 & $<\mathrm{LOQ}$ & 0.31 & $<\mathrm{LOQ}$ & 4.89 & 2.77 & 742.29 & 1457.71 \\
\hline Min & 2130.38 & $<\mathrm{LOQ}$ & 14.67 & $<\mathrm{LOQ}$ & 0.11 & 0.21 & 0.68 & 0.52 & 123.04 & 1104.24 \\
\hline Max & 6397.17 & 4.21 & 70.74 & 0.06 & 0.48 & 0.61 & 12.29 & 6.87 & 2368.46 & 3050.33 \\
\hline Average & 3910.53 & 1.57 & 29.64 & $\sim$ & 0.30 & $\sim$ & 7.00 & 3.23 & 1275.37 & 1900.71 \\
\hline SD & 968.14 & 0.64 & 10.33 & $\sim$ & 0.09 & & 3.13 & 1.59 & 703.46 & 415.56 \\
\hline
\end{tabular}


Cont. Table 2:

\begin{tabular}{|c|c|c|c|c|c|c|c|c|c|c|}
\hline \multirow{2}{*}{ Station } & \multicolumn{10}{|c|}{ Concentration (ppm) } \\
\hline & Li & Mg & Mn & Mo & $\mathrm{Ni}$ & $\mathbf{P b}$ & Sb & v & $\mathrm{Zn}$ & $\mathrm{Hg}$ \\
\hline A1 & 2.26 & 6030.66 & 14.64 & 0.62 & 3.13 & $<\mathrm{LOQ}$ & 0.99 & 4.34 & 2.45 & 0.007 \\
\hline A2 & 2.40 & 5328.40 & 11.31 & 1.18 & 2.41 & $<\mathrm{LOQ}$ & 2.71 & 4.83 & 4.53 & 0.007 \\
\hline A3 & 2.67 & 4663.85 & 12.26 & 0.95 & 2.74 & $<\mathrm{LOQ}$ & 0.78 & 3.53 & 1.72 & 0.005 \\
\hline A4 & 2.68 & 5061.43 & 16.09 & 0.76 & 3.15 & $<\mathrm{LOQ}$ & 1.00 & 4.05 & 2.39 & 0.007 \\
\hline A5 & 3.27 & 6267.58 & 20.59 & 0.71 & 3.76 & $<\mathrm{LOQ}$ & 1.52 & 4.78 & 2.91 & 0.009 \\
\hline B1 & 2.71 & 7035.66 & 10.75 & 0.74 & 1.61 & $<\mathrm{LOQ}$ & 1.11 & 3.56 & 1.44 & 0.005 \\
\hline B2 & 3.06 & 5476.59 & 10.19 & 0.64 & 1.46 & $<\mathrm{LOQ}$ & 1.15 & 3.15 & 1.59 & 0.008 \\
\hline B3 & 3.18 & 5399.00 & 10.30 & 1.05 & 1.96 & $<L O Q$ & 2.45 & 3.30 & 5.32 & 0.031 \\
\hline B4 & 2.42 & 7037.89 & 4.42 & 1.07 & $<\mathrm{LOQ}$ & $<\mathrm{LOQ}$ & 0.73 & 1.04 & $<$ LOQ & 0.007 \\
\hline B5 & 3.17 & 8673.68 & 5.07 & 0.80 & 0.50 & $<\mathrm{LOQ}$ & 2.37 & 1.27 & 4.48 & 0.008 \\
\hline C1 & 2.93 & 6832.20 & 12.07 & 0.66 & 1.63 & $<\mathrm{LOQ}$ & 1.03 & 3.25 & 1.73 & 0.010 \\
\hline C2 & 2.77 & 4716.03 & 4.71 & 0.93 & 0.87 & $<\mathrm{LOQ}$ & 1.31 & 1.74 & 1.57 & 0.006 \\
\hline C3 & 2.85 & 7111.53 & 16.85 & 0.88 & 3.07 & $<L O Q$ & 0.83 & 4.03 & 3.31 & 0.006 \\
\hline C4 & 2.56 & 6179.78 & 13.52 & 0.99 & 2.88 & $<L O Q$ & 0.90 & 3.83 & 2.76 & 0.004 \\
\hline C5 & 1.96 & 4910.89 & 6.56 & $<\mathrm{LOQ}$ & 1.66 & $<\mathrm{LOQ}$ & 0.49 & 2.48 & 1.03 & 0.006 \\
\hline D1 & 1.97 & 5342.45 & 8.75 & 0.72 & 1.70 & $<\mathrm{LOQ}$ & 0.63 & 3.44 & 1.79 & 0.005 \\
\hline D2 & 3.30 & 6490.18 & 21.94 & 1.16 & 4.90 & $<L O Q$ & 0.84 & 6.17 & 4.32 & 0.007 \\
\hline D3 & 3.18 & 9791.48 & 34.42 & 0.73 & 6.85 & $<L O Q$ & 1.07 & 8.39 & 7.00 & 0.012 \\
\hline D4 & 3.85 & 24555.85 & 37.40 & 1.21 & 5.59 & $<L O Q$ & 1.21 & 11.17 & 4.87 & 0.012 \\
\hline D5 & 2.07 & 5757.05 & 8.49 & $<\mathrm{LOQ}$ & 1.80 & $<L O Q$ & 1.07 & 3.57 & 1.07 & 0.008 \\
\hline E1 & 3.92 & 9754.80 & 37.49 & 0.77 & 6.98 & $<\mathrm{LOQ}$ & 1.12 & 10.11 & 7.22 & 0.008 \\
\hline E2 & 3.23 & 7875.70 & 32.16 & 0.73 & 5.25 & $<\mathrm{LOQ}$ & 0.88 & 7.38 & 5.53 & 0.007 \\
\hline E3 & 3.99 & 9272.45 & 47.88 & 0.79 & 7.78 & $<\mathrm{LOQ}$ & 1.60 & 10.32 & 7.29 & 0.010 \\
\hline E4 & 3.26 & 8639.38 & 33.54 & 0.64 & 6.15 & $<L O Q$ & 0.96 & 8.38 & 5.73 & 0.006 \\
\hline E5 & 3.63 & 17738.80 & 32.16 & 0.93 & 5.34 & $<L O Q$ & 0.60 & 10.02 & 4.82 & 0.008 \\
\hline
\end{tabular}


Cont. Table 2:

\begin{tabular}{|c|c|c|c|c|c|c|c|c|c|c|}
\hline \multirow{2}{*}{ Station } & \multicolumn{10}{|c|}{ Concentration (ppm) } \\
\hline & $\mathbf{L i}$ & $\mathrm{Mg}$ & $\mathrm{Mn}$ & Mo & $\mathrm{Ni}$ & $\mathrm{Pb}$ & Sb & v & $\mathrm{Zn}$ & $\mathrm{Hg}$ \\
\hline $\mathbf{F 1}$ & 1.88 & 8258.30 & 27.40 & $<\mathrm{LOQ}$ & 2.21 & $<L O Q$ & 0.40 & 4.48 & 2.98 & 0.007 \\
\hline F2 & 2.69 & 6266.18 & 22.38 & 0.64 & 4.58 & $<\mathrm{LOQ}$ & 0.65 & 6.68 & 5.60 & 0.010 \\
\hline F3 & 3.01 & 8090.76 & 35.53 & $<\mathrm{LOQ}$ & 7.26 & $<\mathrm{LOQ}$ & 0.66 & 9.01 & 6.88 & 0.009 \\
\hline F4 & 1.84 & 7070.26 & 12.80 & 0.63 & 1.77 & $<\mathrm{LOQ}$ & 0.48 & 3.33 & 3.80 & 0.014 \\
\hline F5 & 3.87 & 42782.32 & 54.66 & 0.54 & 5.56 & $\angle \mathrm{LOQ}$ & 0.62 & 11.88 & 5.52 & 0.009 \\
\hline G1 & 2.70 & 6878.74 & 21.63 & 0.65 & 4.28 & $<L O Q$ & 0.31 & 6.66 & 4.87 & 0.009 \\
\hline G2 & 1.85 & 6255.41 & 8.32 & $<\mathrm{LOQ}$ & 1.08 & $<\mathrm{LOQ}$ & 0.71 & 2.25 & 1.50 & 0.006 \\
\hline G3 & 3.21 & 8745.67 & 37.92 & 0.54 & 8.55 & $<\mathrm{LOQ}$ & 0.28 & 10.34 & 9.95 & 0.010 \\
\hline G4 & 3.44 & 9221.52 & 36.96 & 0.61 & 8.24 & $<\mathrm{LOQ}$ & 0.38 & 9.74 & 8.01 & 0.014 \\
\hline G5 & 2.57 & 16581.61 & 29.78 & $<\mathrm{LOQ}$ & 4.80 & $<\mathrm{LOQ}$ & 0.80 & 8.84 & 6.63 & 0.010 \\
\hline H1 & 3.49 & 16364.40 & 32.55 & 0.71 & 6.67 & 0.67 & $<L O Q$ & 13.51 & 9.92 & 0.014 \\
\hline H2 & 3.68 & 9201.34 & 40.80 & 0.43 & 8.00 & $<\angle O Q$ & 0.44 & 10.97 & 9.97 & 0.011 \\
\hline H3 & 2.22 & 5009.11 & 12.00 & 0.52 & 1.91 & $<L O Q$ & 0.86 & 3.45 & 2.59 & 0.009 \\
\hline $\mathrm{H} 4$ & 2.00 & 5858.31 & 18.18 & 0.82 & 4.01 & $\angle \mathrm{LOQ}$ & 1.48 & 6.89 & 7.04 & 0.006 \\
\hline H5 & 2.86 & 7971.98 & 25.54 & 2.35 & 4.99 & $<L O Q$ & 0.61 & 7.68 & 5.83 & 0.021 \\
\hline 11 & 3.14 & 9890.73 & 32.71 & 0.92 & 5.98 & $<L O Q$ & 1.16 & 8.34 & 7.59 & 0.007 \\
\hline 12 & 2.61 & 6785.52 & 21.84 & 0.95 & 4.70 & $<\angle O Q$ & 0.45 & 7.21 & 7.80 & 0.012 \\
\hline 13 & 3.26 & 9169.24 & 35.52 & 0.59 & 6.60 & $\angle \mathrm{LOQ}$ & 0.36 & 9.34 & 8.59 & 0.009 \\
\hline 14 & 2.55 & 5710.70 & 21.08 & 0.68 & 3.34 & $\angle \mathrm{LOQ}$ & 1.63 & 5.12 & 5.77 & 0.008 \\
\hline 15 & 3.32 & 10287.08 & 36.71 & $<\mathrm{LOQ}$ & 7.44 & $<\mathrm{LOQ}$ & 0.53 & 9.28 & 8.14 & 0.010 \\
\hline J1 & 2.49 & 7194.68 & 20.94 & 0.66 & 4.53 & $<\mathrm{LOQ}$ & 0.78 & 8.02 & 7.94 & 0.012 \\
\hline $\mathrm{J2}$ & 2.64 & 9684.78 & 32.23 & 0.57 & 6.69 & $\angle \mathrm{LOQ}$ & 0.76 & 8.03 & 8.88 & 0.011 \\
\hline J3 & 4.14 & 9934.36 & 29.51 & 1.36 & 6.60 & $\angle \mathrm{LOQ}$ & 1.95 & 8.43 & 9.98 & 0.007 \\
\hline J4 & 3.17 & 9509.20 & 33.19 & 0.58 & 7.28 & $<\mathrm{LOQ}$ & 0.37 & 8.50 & 7.73 & 0.010 \\
\hline J5 & 2.44 & 7862.73 & 12.98 & 0.63 & 2.31 & $<\mathrm{LOQ}$ & 0.82 & 3.89 & 2.97 & 0.010 \\
\hline Min & 1.84 & 4663.85 & 4.42 & $<\mathrm{LOQ}$ & $<\mathrm{LOQ}$ & $<\mathrm{LOQ}$ & 0.28 & 1.04 & 1.03 & 0.00 \\
\hline Max & 4.14 & 42782.32 & 54.66 & 2.35 & 8.55 & 0.67 & 2.71 & 13.51 & 9.98 & 0.03 \\
\hline Average & 2.89 & 8930.56 & 23.13 & 0.81 & 4.34 & $\sim$ & 0.96 & 6.40 & 5.17 & 0.01 \\
\hline SD & 0.60 & 6108.65 & 12.40 & 0.32 & 2.30 & $\sim$ & 0.55 & 3.13 & 2.72 & 0.00 \\
\hline
\end{tabular}


Table 3: Metal Concentration results from different grinding time.

\begin{tabular}{|c|c|c|c|c|c|c|c|c|c|}
\hline \multicolumn{2}{|c|}{ Parameter } & A3 -15min & A3 - 30min & D3 - 15min & D3 - 30min & E1 - 15min & E1 - 30min & I1 - 15min & I1 - 30min \\
\hline Al & \multirow{18}{*}{ ppm } & 4053.64 & 4186.25 & 7077.53 & 7322.84 & 7561.50 & 8338.20 & 11744.07 & 11858.08 \\
\hline As & & $<\mathrm{LOQ}$ & $<\mathrm{LOQ}$ & $<\mathrm{LOQ}$ & $<\mathrm{LOQ}$ & $<\mathrm{LOQ}$ & $<\mathrm{LOQ}$ & 1.46 & 1.85 \\
\hline $\mathbf{B a}$ & & 29.94 & 60.51 & 48.29 & 48.78 & 40.59 & 55.44 & 108.60 & 102.88 \\
\hline Be & & $<\mathrm{LOQ}$ & $<\mathrm{LOQ}$ & 0.08 & 0.08 & 0.10 & 0.08 & 0.23 & 0.24 \\
\hline Cd & & 0.20 & 0.18 & 0.18 & 0.19 & 0.20 & 0.21 & 0.21 & 0.20 \\
\hline Co & & $<\mathrm{LOQ}$ & $<\mathrm{LOQ}$ & 0.73 & 0.65 & 1.19 & 0.84 & 1.58 & 1.54 \\
\hline $\mathrm{Cr}$ & & 5.95 & 7.33 & 15.16 & 15.88 & 19.13 & 20.95 & 30.70 & 31.38 \\
\hline $\mathbf{C u}$ & & 2.83 & 0.81 & 3.07 & 5.27 & 7.08 & 5.39 & 9.16 & 10.25 \\
\hline $\mathbf{F e}$ & & 1020.78 & 996.14 & 2984.64 & 3005.88 & 3413.38 & 3479.33 & 5589.67 & 5752.71 \\
\hline $\mathbf{K}$ & & 2008.70 & 2182.31 & 3064.81 & 3185.71 & 3879.81 & 3431.04 & 5083.79 & 4976.72 \\
\hline $\mathbf{L i}$ & & 3.68 & 3.18 & 5.61 & 5.80 & 5.25 & 6.64 & 8.15 & 8.32 \\
\hline Mg & & 6280.68 & 6131.01 & 15201.00 & 15458.02 & 16812.84 & 17359.82 & 32867.89 & 33081.12 \\
\hline Mn & & 15.33 & 15.02 & 51.68 & 51.25 & 59.91 & 61.98 & 90.21 & 92.92 \\
\hline Mo & & 0.28 & 0.90 & 0.16 & 0.29 & 0.34 & 0.52 & 2.75 & 1.92 \\
\hline $\mathbf{N i}$ & & 3.71 & 3.57 & 9.92 & 10.11 & 11.57 & 11.57 & 17.12 & 17.49 \\
\hline $\mathbf{P b}$ & & $<\mathrm{LOQ}$ & $<\mathrm{LOQ}$ & $<\mathrm{LOQ}$ & $<\mathrm{LOQ}$ & $<\mathrm{LOQ}$ & $<\mathrm{LOQ}$ & $<\mathrm{LOQ}$ & 1.10 \\
\hline $\mathbf{V}$ & & 4.52 & 4.43 & 12.49 & 12.53 & 15.99 & 16.42 & 26.59 & 27.67 \\
\hline Zn & & 0.88 & 4.34 & 6.26 & 4.23 & 10.69 & 9.45 & 17.04 & 18.18 \\
\hline Sand & \multirow{3}{*}{$\mu \mathrm{m}$} & 25.88 & 25.91 & 14.28 & 18.12 & 20.71 & 21.48 & 20.03 & 21.18 \\
\hline Silt & & 53.16 & 50.55 & 65.62 & 60.8 & 59.7 & 57.24 & 60.33 & 57.29 \\
\hline Clay & & 20.96 & 23.54 & 20.10 & 21.08 & 19.59 & 21.28 & 19.64 & 21.53 \\
\hline
\end{tabular}




\section{Appendix B: Quality Control Criteria}

Table 1: Data on Limit of Detection (LOD) and Limit of Quantitation (LOQ) calculated for the method of analysis used.

\begin{tabular}{|c|c|c|}
\hline \multirow{2}{*}{ Metal Analyte } & \multicolumn{2}{|c|}{ LOD and LOQ (ppb) for Soil/Sediments (Sample Basis) } \\
\cline { 2 - 3 } & LOD & LOQ \\
\hline $\mathbf{A l}$ & 360.0 & 1110.0 \\
\hline $\mathbf{A s}$ & 280.0 & 910.0 \\
\hline $\mathbf{B a}$ & 47.0 & 145.0 \\
\hline $\mathbf{B e}$ & 3.0 & 9.0 \\
\hline $\mathbf{C a}$ & 6100.0 & 19200.0 \\
\hline $\mathbf{C d}$ & 10.0 & 45.0 \\
\hline $\mathbf{C o}$ & 45.0 & 165.0 \\
\hline $\mathbf{C r}$ & 90.0 & 230.0 \\
\hline $\mathbf{C u}$ & 1065.0 & 3425.0 \\
\hline $\mathbf{F e}$ & 365.0 & 1035.0 \\
\hline $\mathbf{K}$ & 96.0 & 280.0 \\
\hline $\mathbf{L i}$ & 5.0 & 10.0 \\
\hline $\mathbf{M g}$ & 245.0 & 825.0 \\
\hline $\mathbf{M n}$ & 27.0 & 84.0 \\
\hline $\mathbf{M o}$ & 125.0 & 430.0 \\
\hline $\mathbf{N a}$ & 53.0 & 217.0 \\
\hline $\mathbf{N i}$ & 58.0 & 235.0 \\
\hline $\mathbf{P b}$ & 74.0 & 470.0 \\
\hline $\mathbf{S r}$ & 51.0 & 152.0 \\
\hline $\mathbf{V}$ & 20.0 & 77.0 \\
\hline $\mathbf{Z n}$ & 130.0 & 420.0 \\
\hline & & \\
\hline & & \\
\hline
\end{tabular}

Table 2. Laboratory Replicates calculated for the metal analyses of the sediments samples collected from Doha Bay during May 2012 sampling.(Phase I)

\begin{tabular}{|c|c|c|c|c|c|c|c|c|c|c|}
\hline \multirow{2}{*}{ Station } & \multicolumn{10}{|c|}{ Concentration (ppm) } \\
\cline { 2 - 12 } & $\mathbf{A l}$ & As & Ba & Be & Cd & Co & $\mathbf{C r}$ & $\mathbf{C u}$ & $\mathbf{F e}$ & $\mathbf{K}$ \\
\hline B3 & 1704.26 & $<\mathrm{LOQ}$ & 10.47 & $<\mathrm{LOQ}$ & 0.19 & $<\mathrm{LOQ}$ & 2.98 & 0.87 & 595.95 & 1452.14 \\
\hline B3LR & 1470.39 & $<\mathrm{LOQ}$ & 9.04 & $<\mathrm{LOQ}$ & 0.14 & $<\mathrm{LOQ}$ & 3.13 & 0.84 & 629.22 & 1379.24 \\
\hline F4 & 1822.43 & $<\mathrm{LOQ}$ & 11.76 & $<\mathrm{LOQ}$ & 0.15 & $<\mathrm{LOQ}$ & 4.28 & 2.04 & 629.32 & 1588.63 \\
\hline F4LR & 1580.93 & 0.91 & 11.01 & $<\mathrm{LOQ}$ & 0.12 & $<\mathrm{LOQ}$ & 3.40 & 1.41 & 557.17 & 1406.91 \\
\hline H3 & 1899.32 & $<\mathrm{LOQ}$ & 12.64 & $<\mathrm{LOQ}$ & 0.12 & $<\mathrm{LOQ}$ & 3.88 & 1.39 & 735.13 & 1565.40 \\
\hline H3LR & 2120.74 & $<\mathrm{LOQ}$ & 12.56 & $<\mathrm{LOQ}$ & 0.19 & $<\mathrm{LOQ}$ & 4.07 & 1.63 & 770.51 & 1687.55 \\
\hline I5 & 3540.04 & $<\mathrm{LOQ}$ & 26.64 & 0.02 & 0.08 & 0.61 & 9.17 & 4.98 & 2221.48 & 2040.78 \\
\hline I5LR & 3289.29 & $<\mathrm{LOQ}$ & 33.21 & $<\mathrm{LOQ}$ & 0.09 & 0.67 & 9.16 & 4.30 & 2098.72 & 1654.65 \\
\hline
\end{tabular}


Cont. Table 2.

\begin{tabular}{|c|c|c|c|c|c|c|c|c|c|c|}
\hline \multirow{2}{*}{ Station } & \multicolumn{10}{|c|}{ Concentration (ppm) } \\
\hline & $\mathbf{L i}$ & Mg & Mn & Mo & $\mathbf{N i}$ & $\mathbf{P b}$ & Sb & $\mathbf{V}$ & $\mathbf{Z n}$ & $\mathrm{Hg}$ \\
\hline B3 & 2.58 & 5321.34 & 8.76 & $<\mathrm{LOQ}$ & 1.33 & $<\mathrm{LOQ}$ & 0.65 & 3.10 & 3.21 & 0.003 \\
\hline B3LR & 2.42 & 5964.00 & 8.96 & $<\mathrm{LOQ}$ & 1.45 & $<\mathrm{LOQ}$ & 0.34 & 3.24 & 3.46 & 0.002 \\
\hline F4 & 2.56 & 6713.23 & 11.68 & $<\mathrm{LOQ}$ & 1.78 & $<\mathrm{LOQ}$ & 0.52 & 3.17 & 4.55 & 0.005 \\
\hline F4LR & 2.27 & 6293.29 & 12.03 & $<\mathrm{LOQ}$ & 1.68 & $<\mathrm{LOQ}$ & 0.13 & 2.71 & 4.84 & 0.004 \\
\hline H3 & 2.56 & 5237.53 & 11.55 & $<\mathrm{LOQ}$ & 1.81 & $<\mathrm{LOQ}$ & 0.22 & 3.36 & 3.87 & 0.006 \\
\hline H3LR & 2.70 & 5299.44 & 11.58 & $<\mathrm{LOQ}$ & 1.84 & $<\mathrm{LOQ}$ & 0.21 & 3.59 & 4.28 & 0.006 \\
\hline I5 & 3.89 & 10179.98 & 34.22 & $<\mathrm{LOQ}$ & 6.43 & $<\mathrm{LOQ}$ & 0.00 & 9.27 & 9.24 & 0.008 \\
\hline I5LR & 4.07 & 9559.95 & 32.34 & $<\mathrm{LOQ}$ & 6.17 & $<\mathrm{LOQ}$ & 1.12 & 8.73 & 10.85 & 0.006 \\
\hline
\end{tabular}

Table 3. Laboratory Replicates calculated for the metal analyses of the sediments samples collected from Doha Bay during December 2012 sampling.(Phase II)

\begin{tabular}{|c|c|c|c|c|c|c|c|c|c|c|c|}
\hline \multirow{2}{*}{ Station } & \multicolumn{10}{|c|}{ Concentration (ppm) } \\
\cline { 2 - 14 } & Al & As & Ba & Be & Cd & Co & Cr & Cu & Fe & K & Li \\
\hline D2 & 4485.85 & 2.25 & 26.76 & 0.01 & 0.38 & $<$ LOQ & 7.15 & 2.85 & 1380.87 & 2190.28 & 3.30 \\
\hline D2LR & 4314.06 & 1.43 & 26.00 & 0.02 & 0.39 & $<$ LOQ & 6.46 & 2.70 & 1262.06 & 2118.30 & 3.25 \\
\hline E1 & 5640.99 & 1.17 & 33.27 & 0.05 & 0.36 & 0.23 & 11.30 & 4.83 & 2002.82 & 2447.15 & 3.92 \\
\hline E1LR & 5547.49 & 1.50 & 32.71 & 0.05 & 0.30 & 0.28 & 11.25 & 5.07 & 2027.97 & 2405.88 & 3.78 \\
\hline H5 & 3995.00 & 4.21 & 27.47 & $<$ LOQ & 0.31 & $<$ LOQ & 7.50 & 4.45 & 1623.99 & 1885.39 & 2.86 \\
\hline H5LR & 3711.93 & 4.46 & 26.53 & $<$ LOQ & 0.31 & $<$ LOQ & 7.51 & 4.07 & 1614.12 & 1787.00 & 2.72 \\
\hline
\end{tabular}

Cont. Table 3

\begin{tabular}{|c|c|c|c|c|c|c|c|c|c|}
\hline \multirow{2}{*}{ Station } & \multicolumn{9}{|c|}{ Concentration (ppm) } \\
\cline { 2 - 11 } & $\mathbf{M g}$ & $\mathbf{M n}$ & $\mathbf{M o}$ & $\mathbf{N i}$ & $\mathbf{P b}$ & $\mathbf{S b}$ & $\mathbf{V}$ & $\mathbf{Z n}$ & $\mathbf{H g}$ \\
\hline D2 & 6490.18 & 21.94 & 1.16 & 4.90 & $<$ LOQ & 0.84 & 6.17 & 4.32 & 0.007 \\
\hline D2LR & 6092.35 & 20.33 & 1.07 & 4.58 & <LOQ & 1.07 & 5.64 & 3.70 & 0.005 \\
\hline E1 & 9754.80 & 37.49 & 0.77 & 6.98 & $<$ LOQ & 1.12 & 10.11 & 7.22 & 0.008 \\
\hline E1LR & 9931.75 & 38.11 & 1.08 & 7.17 & <LOQ & 0.71 & 10.17 & 7.92 & 0.007 \\
\hline H5 & 7971.98 & 25.54 & 2.35 & 4.99 & <LOQ & 0.61 & 7.68 & 5.83 & 0.021 \\
\hline H5LR & 8107.06 & 25.01 & 2.25 & 4.88 & $<$ LOQ & 0.44 & 7.67 & 5.49 & 0.011 \\
\hline
\end{tabular}


Table 4: Continuous calibration verification (CCV) check measured during May and December 2012 study.

\begin{tabular}{|c|c|c|c|c|}
\hline \multirow{2}{*}{ Metal } & \multicolumn{2}{|c|}{ Phase I } & \multicolumn{2}{|c|}{ Phase II } \\
\hline & $\begin{array}{l}\text { CCV - 1 } \\
100 \text { ppb } \\
\end{array}$ & $\begin{array}{l}\text { CCV - } 2 \\
100 \text { ppb }\end{array}$ & $\begin{array}{l}\text { CCV - } 1 \\
100 \text { ppb }\end{array}$ & $\begin{array}{l}\text { CCV - 1 } \\
100 \text { ppb }\end{array}$ \\
\hline Al & 93.37 & 138.81 & 117.85 & 118.20 \\
\hline As & 105.30 & 108.90 & 102.86 & 103.65 \\
\hline $\mathbf{B a}$ & 104.62 & 110.38 & 107.70 & 108.47 \\
\hline $\mathbf{B e}$ & 107.23 & 115.85 & 102.58 & 100.77 \\
\hline Cd & 104.01 & 112.23 & 103.08 & 100.33 \\
\hline Co & 109.51 & 114.90 & 106.70 & 104.14 \\
\hline $\mathrm{Cr}$ & 105.81 & 110.72 & 105.49 & 105.92 \\
\hline $\mathrm{Cu}$ & 97.81 & 102.32 & 104.85 & 104.39 \\
\hline $\mathrm{Fe}$ & 11715.00 & 12590.92 & 10878.82 & 11033.99 \\
\hline $\mathbf{K}$ & 8390.52 & 8675.58 & 10044.71 & 9746.93 \\
\hline $\mathbf{L i}$ & 79.61 & 85.06 & 125.63 & 119.95 \\
\hline $\mathrm{Mg}$ & 10230.75 & 10917.49 & 10537.35 & 10510.72 \\
\hline Mn & 107.36 & 113.98 & 105.95 & 103.93 \\
\hline Mo & 104.81 & 108.03 & 104.02 & 102.30 \\
\hline $\mathrm{Ni}$ & 107.93 & 112.50 & 106.34 & 107.89 \\
\hline $\mathbf{P b}$ & 111.90 & 118.39 & 107.94 & 104.28 \\
\hline $\mathbf{S b}$ & 101.60 & 107.47 & 106.48 & 105.84 \\
\hline $\mathbf{V}$ & 103.99 & 113.63 & 104.70 & 106.77 \\
\hline Zn & 108.01 & 115.95 & 103.11 & 104.93 \\
\hline
\end{tabular}


Table 5: Internal calibration verification (ICV) check measured during May and December 2012 study.

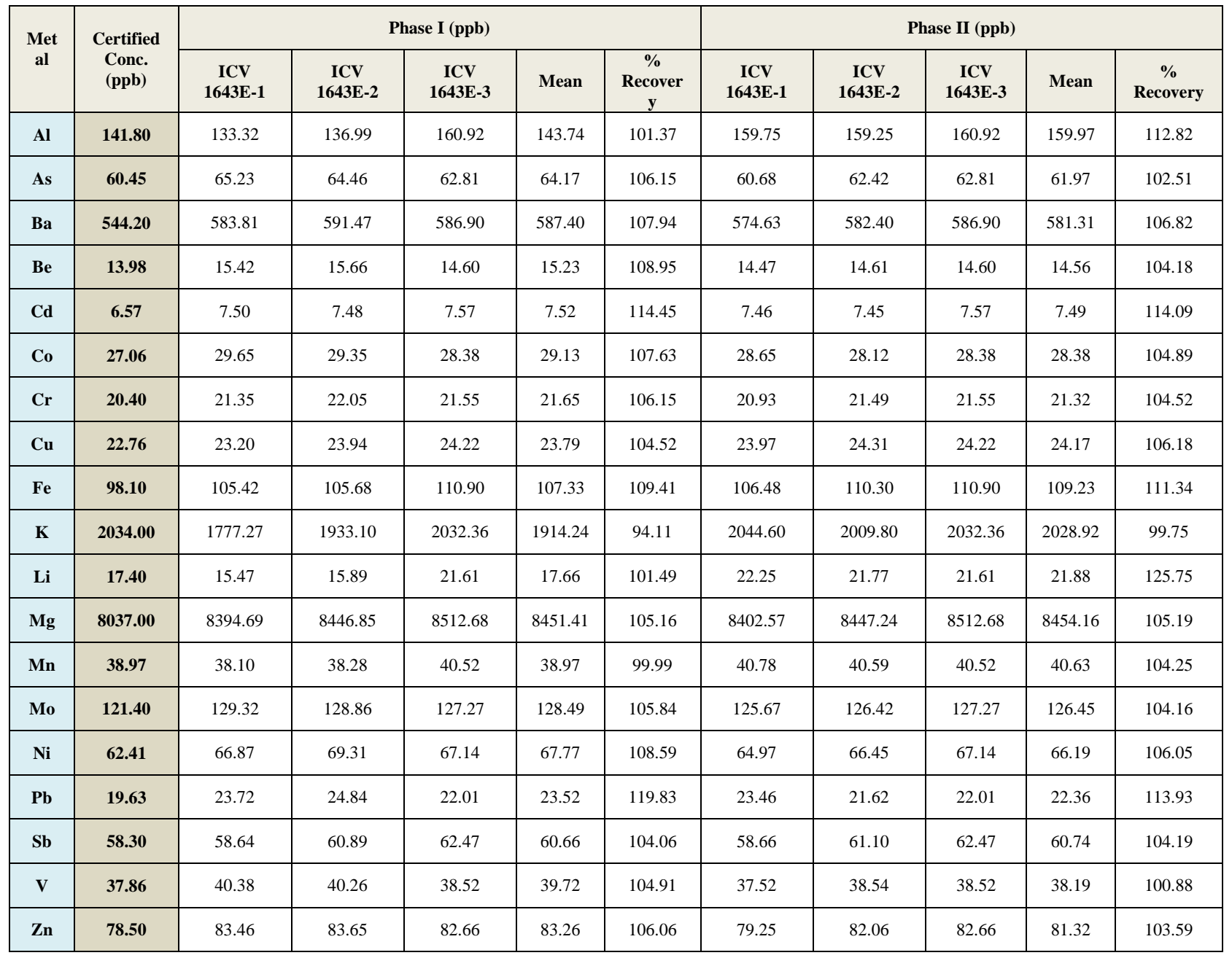


Table 6: Certified Reference Material (CRM) measured during May and December 2012 study.

\begin{tabular}{|c|c|c|c|c|c|c|c|c|c|c|c|}
\hline \multirow{2}{*}{ Metal } & \multirow{2}{*}{$\begin{array}{c}\text { Certified } \\
\text { Conc. } \\
(\text { ppm) }\end{array}$} & \multicolumn{5}{|c|}{ Phase I (ppm) } & \multicolumn{5}{|c|}{ Phase II (ppm) } \\
\hline & & CRM - 1 & CRM - 2 & CRM - 3 & Mean & $\begin{array}{c}\% \\
\text { Recovery }\end{array}$ & CRM - 1 & CRM - 2 & CRM - 3 & Mean & $\begin{array}{c}\% \\
\text { Recovery }\end{array}$ \\
\hline Al & 66200 & 64962.59 & 64720.04 & 67793.45 & 65825.36 & 99.434 & 68975.74 & 66602.41 & 68693.79 & 68090.65 & 102.86 \\
\hline As & 26.2 & 25.01 & 29.09 & 26.11 & 26.74 & 102.06 & 25.30 & 23.40 & 23.89 & 24.20 & 92.35 \\
\hline $\mathbf{B a}$ & I & 990.39 & 955.70 & 990.85 & 978.98 & l & 943.49 & 891.15 & 925.64 & 920.09 & I \\
\hline $\mathrm{Be}$ & 1.00 & 0.89 & 0.94 & 0.90 & 0.91 & 91.048 & 1.12 & 1.05 & 1.10 & 1.09 & 109.16 \\
\hline Cd & 2.11 & 2.83 & 2.76 & 2.90 & 2.83 & 134.1 & 2.46 & 2.18 & 2.30 & 2.31 & 109.69 \\
\hline Co & 11.50 & 9.54 & 9.96 & 9.91 & 9.81 & 85.266 & 10.00 & 9.27 & 9.52 & 9.60 & 83.45 \\
\hline $\mathrm{Cr}$ & 90.00 & 81.47 & 82.10 & 81.78 & 81.78 & 90.871 & 80.77 & 75.25 & 79.17 & 78.39 & 87.10 \\
\hline $\mathrm{Cu}$ & 310.00 & 333.53 & 333.39 & 339.77 & 335.56 & 108.25 & 316.23 & 294.94 & 300.24 & 303.80 & 98.00 \\
\hline $\mathrm{Fe}$ & 40900.00 & 41869.01 & 41586.81 & 44214.09 & 42556.64 & 104.05 & 39625.49 & 37777.92 & 39411.07 & 38938.16 & 95.20 \\
\hline $\mathbf{K}$ & 12400.00 & 15502.97 & 15676.09 & 15445.95 & 15541.67 & 125.34 & 13935.02 & 13620.12 & 13648.48 & 13734.54 & 110.76 \\
\hline $\mathbf{L i}$ & 32.20 & 36.18 & 36.10 & 36.41 & 36.23 & 112.52 & 32.05 & 30.85 & 31.78 & 31.56 & 98.02 \\
\hline Mg & 14700.00 & 14117.83 & 14010.65 & 14437.22 & 14188.57 & 96.521 & 13666.05 & 12786.79 & 13421.03 & 13291.29 & 90.42 \\
\hline Mn & 440.00 & 446.83 & 439.87 & 457.59 & 448.10 & 101.84 & 418.17 & 394.94 & 410.97 & 408.03 & 92.73 \\
\hline Mo & 5.43 & 5.10 & 4.90 & 4.99 & 5.00 & 92.039 & 6.16 & 5.74 & 6.11 & 6.00 & 110.54 \\
\hline $\mathbf{N i}$ & 39.50 & 41.84 & 40.49 & 40.17 & 40.83 & 103.37 & 40.28 & 38.33 & 40.86 & 39.82 & 100.82 \\
\hline $\mathbf{P b}$ & 183.00 & 176.78 & 174.37 & 186.67 & 179.27 & 97.964 & 162.97 & 153.45 & 170.61 & 162.34 & 88.71 \\
\hline Sb & 11.30 & 12.17 & 12.51 & 13.16 & 12.61 & 111.61 & 10.82 & 8.43 & 9.34 & 9.53 & 84.33 \\
\hline V & 133.00 & 129.05 & 129.67 & 136.91 & 131.88 & 99.156 & 137.80 & 130.51 & 137.84 & 135.38 & 101.79 \\
\hline Zn & 364.00 & 370.78 & 377.50 & 383.52 & 377.27 & 103.65 & 371.23 & 343.59 & 357.27 & 357.36 & 98.18 \\
\hline
\end{tabular}




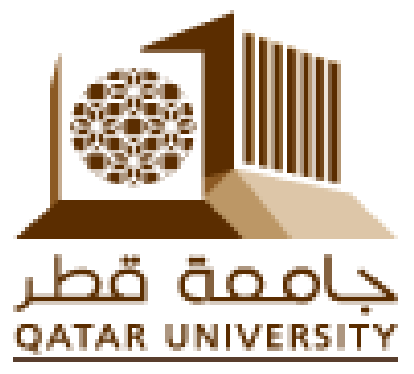

Office of Vice President for Research

Environmental Studies Center (ESC)

\author{
ESC-SOP-ICPOES-01
}

\title{
Simultaneous Determination of Minerals and Heavy Metals in Soil and Sediment Samples by ICP-AES
}

\section{$1.0 \quad$ Title}

Simultaneous determination of minerals and heavy metals (Ag, Al, As, Be, Ca, Cd, Co, $\mathrm{Cr}, \mathrm{Cu}, \mathrm{Fe}, \mathrm{K}, \mathrm{Mg}, \mathrm{Mn}, \mathrm{Mo}, \mathrm{Na}, \mathrm{Ni}, \mathrm{Pb}, \mathrm{Sb}, \mathrm{Se}, \mathrm{Sr}, \mathrm{Th}, \mathrm{Th}, \mathrm{U}, \mathrm{V}, \mathrm{Zn}$ ) in sea sediment and soil samples using Inductively Coupled Plasma-Atomic Emission Spectrometry (ICPAES). 


\subsection{Purpose}

To determine the levels of minerals and heavy metals (Ag, Al, As, Be, Ca, Cd, Co, Cr, $\mathrm{Cu}, \mathrm{Fe}, \mathrm{K}, \mathrm{Mg}, \mathrm{Mn}, \mathrm{Mo}, \mathrm{Na}, \mathrm{Ni}, \mathrm{Pb}, \mathrm{Sb}, \mathrm{Se}, \mathrm{Sr}, \mathrm{Th}, \mathrm{U}, \mathrm{V}, \mathrm{Zn}$ ) in sea sediment and soil samples.

\subsection{Scope}

This method describes the simultaneous determination of total and acid leachable metals in sea sediment and soil and may be applicable to other matrices with appropriate sample preparation technique(s).

\subsection{Responsibility}

4.1 Validated Analyst(s)

\subsection{Quality Coordinator}

4.3 Quality Manager

4.4 Technical Manager

\subsection{Director}

\subsection{Principle}

A known quantity of sample is digested with acids and the solution is aspirated into the plasma generated by inductively coupled plasma source. The atomized elements produce characteristic emission spectral lines, which are separated by a simultaneous optical spectrometer. The concentration of the elements in the solution is deduced from the calibration curve of each element.

\subsection{Summary of method}

A portion of homogeneous soil and marine sediment samples are accurately weighed and treated with acids to destroy the organic matter and solubilized the recoverable elements. 
After cooling, the sample is made up to the volume with deionized water and filtered if turbid. The sample solution is aspirated through nebulizer and the resulting aerosol is transported to the plasma torch where excitation occurs. Element specific emission spectra are produced by radio-frequency inductively coupled plasma. The spectra' are dispersed by a grating spectrometer, and intensities of the line spectra are monitored at specific wavelengths by a charged coupled detector. A fitted background correction is used to correct the blank signal and matrix effect. Background correction is not required in cases of line broadening where a background correction measurement would actually degrade the analytical result.

\subsection{Safety and Warning}

7.1 Laboratory is a high risk area, proper care shall be taken while handling the chemicals, reagents etc. Each chemical shall be regarded as a potential health hazard and exposure to these compounds should be as low as reasonably achievable. Use proper protective equipment.

7.2 Always wear laboratory coat and use safety glasses for eye protection

7.3 Use chemical resistant gloves when handling concentrated standards

7.4 The acidification of samples and standards containing reactive materials may result in the release of toxic gases. Acidification and digestion should be done in fume hood.

7.5 Avoid ICP-Plasma radiation by wearing safety goggles. 
7.6 Area of high, lethal voltage exists within the instrument. Never touch parts of the instrument, which are not intended for access by the instrument operator.

\subsection{Reagents and Materials}

8.1 Acids used in the preparation of standards and samples shall be of high purity grade or equivalent.

8.1.1 Conc. hydrochloric acid, MERC, Aristar grade or equiv.

8.1.2 Conc. nitric acid, MERC, Aristar grade or equiv.

8.1.3 Hydrofluoric acid, MERC, Aristar grade or equiv.

8.2 Hydrogen peroxide, Aristar grade, BDH or equiv.

8.3 Deionized water: Deionized water from Milli-Q Gradient/Milli-Q, Millipore or equiv.

8.4 Argon gas (99.99 purity or more)

8.5 Filter paper (Whatman 42 or equiv.)

8.6 0.45 um filter, Aqueous, Millipore or equiv.

8.7 Automatic pipette, 100, 150, 500, 1000 and $5000 \mu 1$ (Transferpette, Germany), calibrated.

8.8 Glass pipettes, bulb $(0.5,1, \& 2.0 \mathrm{ml})$, calibrated.

8.9 Volumetric flasks class A (20,50 and $100 \mathrm{ml})$.

8.10 Standard Solution with analyte concentration of (a) $(10 \mathrm{mg} / \mathrm{l})$ of $(\mathrm{Ag}, \mathrm{Al}, \mathrm{As}, \mathrm{B}, \mathrm{Ba}$ $\mathrm{Be}, \mathrm{Ca}, \mathrm{Cd}, \mathrm{Co}, \mathrm{Cr}, \mathrm{Cu}, \mathrm{Mn}, \mathrm{Mo}, \mathrm{Ni}, \mathrm{Pb}, \mathrm{Li}, \mathrm{Sb}, \mathrm{Se}, \mathrm{Sn}, \mathrm{V}, \mathrm{Zn}$ ) and (b) (1000 $\mathrm{mg} / \mathrm{l})$ : $\mathrm{Ca}, \mathrm{K}, \mathrm{Fe}, \mathrm{Mg}, \mathrm{Na} \& \mathrm{Sr}$ (Accustandard or equiv.). Expired standards, if any, shall be revalidated against validated standards by preparing suitable dilutions. Agreement within $2 \%$ will be necessary for revalidation and the expiry date is further extended to 1 year and will be noted on the bottles. 
8.11 Mixed standard solution, $1.0 \mu \mathrm{g} / \mathrm{ml}$ (calibration check standard): AccuTrace, QCS-01-5 or equiv.

8.12 Quality Control Sample: Certified Reference Material (CRM), Marine sediment (PACS-2) and Soil (IAEA 433\& 407).

\subsection{Equipment and operating conditions:}

\subsection{Equipment}

9.1.1 Inductively Coupled Argon Plasma - Atomic Emission spectrometer (ICPAES), Perkin-Elmer, Optima 5300 DV, Simultaneous, with background correction, auto-fit multi-calibration curve fitting, signal to background ratio (SBR) and signal to root background ratio.

9.1.2 Computer Personal Computer (Dell GX 620 Optiplex) with Laser jet printer (HP 1320)

\subsubsection{WINLAB 32 software}

9.1.4 Analytical balance, capacity $220 \pm 0.0001$ g. Precisa 40SM-200A or equiv.

9.1.5 Hot plate Ceran500

9.1.6 Drying Oven, Memmert.

9.1.7 Hot Block digester

\subsection{Operating conditions:}

$\begin{array}{llr}9.2 .1 & \text { Power } & =1.45 \mathrm{KW} \\ 9.2 .2 & \text { Plasma Flow } & =15 \mathrm{~L} / \mathrm{min} \\ 9.2 .3 & \text { Aux. Flow } & =0.5 \mathrm{~L} / \mathrm{min} \\ 9.2 .4 & \text { Neb. Flow } & =0.75 \mathrm{~L} / \mathrm{min} \\ 9.2 .5 & \text { Replicate read time (S) } & =10 \text { Sec. } \\ 9.2 .6 & \text { Sample Uptake time } & =60 \mathrm{Sec} . \\ 9.2 .7 & \text { Rinse Time } & =30 \mathrm{~S}\end{array}$


$\begin{array}{lll}\text { 9.2.8 } & \text { Sample Pump Flow } & =1.5 \mathrm{ml} / \mathrm{min} \\ 9.2 .9 & \text { Instrument stabilization delay } & =15 \mathrm{~S}\end{array}$

\subsection{Calibration standards:}

\subsection{Preparation of calibration standards:}

10.1.1 Mixed standards Intermediate Solution-1 $(1.0 \mu \mathrm{g} / \mathrm{ml})$ : Pipette $5 \mathrm{ml}$ of standard solution (8.10a) into a $50 \mathrm{ml}$ volumetric flask and make up to volume with $2 \%$ nitric acid solution. Transfer the solution in to a screw capped plastic bottle and store in a refrigerator. The solution is stable for 1 month.

10.1.2 Mixed standards Intermediate Solution-2 $(0.1 \mu \mathrm{g} / \mathrm{ml})$ : Pipette $0.5 \mathrm{ml}$ of stock solution (8.10a) into a $50 \mathrm{ml}$ volumetric flask and make up to volume with $2 \%$ nitric acid solution. Transfer the solution in to a screw capped plastic bottle and store in a refrigerator. The solution is prepared fresh every time before use.

10.1.3 Mixed standards Intermediate Solution-3 $(0.001 \mu \mathrm{g} / \mathrm{ml})$ : Pipette $1.0 \mathrm{ml}$ of stock solution (10.1.2) into a $100 \mathrm{ml}$ volumetric flask and make up to volume with $2 \%$ nitric acid solution. Transfer the solution in to a screw capped plastic bottle and store in a refrigerator. The solution is prepared fresh every time before use.

10.1.4 Mixed standard Intermediate Solution-4 (0.0001 $\mu \mathrm{g} / \mathrm{l})$ : Pipette $0.5 \mathrm{ml}$ of stock solution (10.1.2) into a $100 \mathrm{ml}$ volumetric flask and make up to volume with $2 \%$ nitric acid solution. Prepare fresh prior to use.

10.1.5 Prepare the calibration standard solutions in $2 \%$ nitric acid as shown in the table below. Transfer the mixed standard solutions into a screw capped plastic container and store in a refrigerator at $2-8^{\circ} \mathrm{C}$. For some trace elements linearity range is less than $50(\mu \mathrm{g} / \mathrm{ml})$, the analysis of samples shall be carried out within the linear range for such elements. 
Table I : calibration table for 8.10a Analytes

\begin{tabular}{|l|l|l|l|l|l|}
\hline & Conc. of Std. & Volume taken & Volume made up & Conc. of & Shelf life of \\
\hline 8 & 10 & 5 & 50 & 1 & \\
\hline 7 & 10 & 2.5 & 50 & 0.5 & \\
\cline { 1 - 5 } & 10 & 0.5 & 50 & 0.1 & \\
\hline 5 & 1 & 1 & 50 & 0.02 & \\
\hline 4 & 1 & 0.5 & 100 & 0.005 & \\
\hline 3 & 0.1 & 1 & 100 & 0.001 & \\
\hline 2 & 0.1 & 0.5 & 100 & 0.0005 & \\
\hline 1 & 0.005 & 1 & 50 & 0.0001 & \\
\hline
\end{tabular}

Table II : calibration table for $8.10 \mathrm{~b}$ Analytes

\begin{tabular}{|c|c|c|c|c|c|}
\hline & Conc. Of Std. & Volume taken & Volume made up & Conc. Of & Shelf life of \\
\hline 8 & 1000 & 5 & 50 & 100 & \multirow{4}{*}{ 1month } \\
\hline 7 & 1000 & 2.5 & 50 & 50 & \\
\hline 6 & 1000 & 0.5 & 50 & 10 & \\
\hline 5 & 100 & 1 & 50 & 2.0 & \\
\hline 4 & 100 & 0.5 & 100 & 0.5 & \multirow{4}{*}{ Prepare Fresh } \\
\hline 3 & 10 & 1 & 100 & 0.1 & \\
\hline 2 & 10 & 0.5 & 100 & 0.05 & \\
\hline 1 & 0.5 & 1 & 50 & 0.01 & \\
\hline
\end{tabular}

\subsection{Preparation of calibration check standards:}

10.2.1 Calibration check standards shall be prepared by an independent analyst.

10.2.2 Mixed calibration check standard solution $-1(100 \mu \mathrm{g} / \mathrm{l})$ : Pipette $0.5 \mathrm{ml}$ of mixed standard intermediate solution (8.10a) into a $50 \mathrm{ml}$ volumetric flask and make up to volume with $2 \%$ nitric acid solution. Transfer the solution in to a screw capped plastic bottle, the solution is to be prepared fresh.

10.2.3 Mixed calibration check standard solution $-2(50 \mu \mathrm{g} / \mathrm{l})$ : Pipette $5.0 \mathrm{ml}$ of mixed standard intermediate solution ((8.10a) into a $100 \mathrm{ml}$ volumetric flask and make 
up to volume with $2 \%$ nitric acid solution. Transfer solution in to a screw capped plastic bottle, the solution is to be prepared fresh.

\subsection{Preparation of Blanks:}

10.3.1 The calibration blank (CB): $\mathrm{CB}$ is prepared by diluting $2 \mathrm{ml}$ of concentrated nitric acid in $100 \mathrm{ml}$ de ionized water. Prepare sufficient quantity to be used to flush the system between standards and samples.

10.3.2 The reagent blank (RB): RB shall contain the same volumes of all reagents used in the processing of the samples. The reagent blank shall be carried through complete procedure and contain the same acid concentration in the final solution as the sample solution used for analysis.

\subsection{Sample Handling, preservation and Storage}

Collect soil and marine sediment samples in plastic bags, air-dry (if required), grind sieve and then oven dry at $105{ }^{0} \mathrm{C}$ for $3 \mathrm{hrs}$. Store in a desiccators until the analysis time (Moisture in the original sample shall be determined, if results need to be expressed on wet weight basis).

\subsection{Interference:}

12.1 Spectral interferences can be categorized as 1) overlap of spectral line from another element; 2) unresolved overlap of molecular band spectra; 3) background contribution from continuous or recombination phenomena, and 4) background contribution from stray light from the line emission of high concentration elements. The first of these effects can be compensated by utilizing a computer correction of 
the raw data, requiring the monitoring and measurement of the interfering element. The second effect may require selection of an alternate wavelength. The third and fourth effects can be compensated by a background correction. In addition, users of simultaneous multi-element instrumentation must assume the responsibility of verifying the absence of spectral interference from an element that could occur in a sample but for which there is no channel in the instrument array. The interferences of the recommended wavelengths are expressed as concentration equivalents (i.e., false analyte concentrations) arising from $100 \mathrm{ppm}$.

12.2 The effect of physical interferences is generally associated with the sample nebulization. Such properties as change in viscosity and surface tension can cause significant inaccuracies especially in samples that may contain high dissolved solids or acid concentrations. The use of peristaltic pump may decrease these interferences. If these types of interferences are operative, they must be reduced by dilution of the sample and/or utilization of standard addition techniques. Another challenge that can occur from high dissolved solids is salt build up at the tip of the nebulizer. The salt build up affects the aerosol flow rate causing instrumental drift. Wetting the argon prior to nebulization, the use of a tip washer, or sample dilution has been used to control this problem. In addition, it has been reported that better control of the argon flow rate improves instrument performance that is accomplished with the use of mass flow controllers.

12.3 Molecular compound formation, ionization effects and solute vaporization characterize chemical interferences. Normally these effects are not pronounced with the ICP technique, however if observed they can be minimized by careful selection 
of operating conditions. The operating conditions, such as incident power and observation position matrix matching, standard addition and spiking. The interference effects must be evaluated for each individual system.

12.4 Total elements are determined after appropriate digestion procedures. Since digestion techniques increase the dissolved solids contents in the sample, appropriate steps must be taken to correct for potential interference effects.

\subsection{Procedure}

\subsection{Sample Preparation using Microwave for Total Metals:}

13.1.1 Weigh accurately $0.25 \pm 0.05 \mathrm{~g}$ of soil or sediment sample in TFM pressure vessel. Add $9 \mathrm{ml} \mathrm{HNO3} \mathrm{(65 \% )} \mathrm{followed} \mathrm{by} 3 \mathrm{ml}$ of HF while slight shaking carefully in Fume hood until the reaction is over. Place the lid on vessel and close it hand-tight with coupling cap. Keep the vessels in Rotor symmetrically.

13.1.2 Insert the prepared Rotor inside oven so that the position of glass turn table is not disturbed.

13.1.3 Insert the vent tube already connected to vent treatment system from above reaching to top.

13.1.4 Run the programmed microwave oven for digestion.

13.1.5 Take the Rotor out of microwave oven and keep it in fume hood until cools down to room temperature.

13.1.6 Replace the digestion cap with evaporation cap on each pressure vessel. Return the Rotor back to microwave oven and run evaporation program. 
13.1.7 Cool the Rotor so that the solution comes to room temperature, Open the Vessel, transfer solution to $50 \mathrm{ml}$ marked flask.

\subsubsection{Microwave Program}

$\begin{array}{llll}\text { Step } & \text { Time } & \text { Temperature } & \text { Microwave power } \\ 1 & 20 \text { minutes } & 210^{\circ} \mathrm{C} & 1000 \text { Watt } \\ 2 & 30 \text { minutes } & 190^{\circ} \mathrm{C} & 1000 \text { Watt } \\ 3 & 30 \text { minutes } & 185^{\circ} \mathrm{C} & 1000 \text { Watt }\end{array}$

\subsection{Sample Preparation using Microwave for Acid Extractable Metals:}

13.2.1 Weigh accurately $0.25 \pm 0.05 \mathrm{~g}$ of soil or sediment sample (dry weight) into TFM pressure vessel. Moisten the sample with about $5 \mathrm{ml}$ of de-ionized water, add $9 \mathrm{ml} \mathrm{HCl}+3 \mathrm{ml} \mathrm{HNO} 3$ Place the lid on vessel and close it handtight with coupling cap. Keep the vessels in Rotor symmetrically and follow 13.1.2 to 13.1.8.

\subsection{Sample Preparation using Hotplate/Heating Block for Acid Extractable Metals:}

13.3.1 Weigh accurately $0.25 \pm 0.05 \mathrm{~g}$ of soil or sediment sample (dry weight) into a PTFE or glass vessel. Sample weight can be increased depending on the metals concentrations.

Moisten the sample with about $5 \mathrm{ml}$ of de-ionized water, add $9 \mathrm{ml} \mathrm{HCl}+3 \mathrm{ml}$ HNO3 and digest the sample on a hot plate in a fume cupboard. Adjust the temperature of the hot plate so that the sample solution 
will not spurt. Repeat addition of acids ( $\mathrm{HCl}$ and $\mathrm{HNO} 3)$ and continue digestion until a clear solution is obtained.

13.3.2 Cool and quantitatively transfer into a $50 \mathrm{ml}$ volumetric flask and make up to volume with de ionized water.

13.3.3 Filter the solution through Whatman 42 filter paper, if required or otherwise decant carefully. The sample is now ready for analysis.

\subsection{Sample Preparation by using Heating Block for Total metals:}

13.4.1 Weigh accurately $0.25 \pm 0.05 \mathrm{~g}$ of soil or sediment sample in TFM vessel. and follow the below given steps for digestion.

\subsubsection{Heating Block digestion Program for total metals:}

\begin{tabular}{|c|c|c|c|}
\hline Steps & Time & Temperature & To be digested \\
\hline 1 & 30 minutes & $95^{\circ} \mathrm{C}$ & Sample $+9 \mathrm{ml}$ HNO3 \\
\hline 2 & 30 minutes & $95^{\circ} \mathrm{C}$ & Mixture $+3 \mathrm{ml} \mathrm{HF}$ \\
\hline 3 & 60 minutes & $135^{\circ} \mathrm{C}$ & Evaporate to reduce \\
\hline & & $155^{\circ} \mathrm{C}$ & Evaporate to almost dryness \\
\hline
\end{tabular}

13.4.3 Add 3ml $\mathrm{HNO} 3$ followed by $40 \mathrm{ml}$ de ionized water, boil until clear, Cool and quantitatively transfer into a $100 \mathrm{ml}$ volumetric flask, make up to volume with de ionized water.

\subsection{Instrument setup:}

Follow the ICP (Perkin-Elmer, Optima 5300 DV, Simultaneous) instruction manual for instrument set up and operation.

\subsection{Construction of calibration curves:}




\subsubsection{A suitable program was built using ICP WINLAB 32 software}

Selecting the analyte elements with respective wavelengths, sensitivities, interferences and linear regression equation.

13.6.2 Aspirate the prepared mixed calibration standard solutions to construct calibration curves for each element simultaneously.

13.6.3 Aspirate deionized water to remove the memory effects.

13.6.4 The square of correlation coefficient $\left(\mathrm{R}^{2}\right)$ shall not be less than 0.99 for each calibration curve at least up to $20 \mu \mathrm{g} / \mathrm{ml}$. If $\mathrm{R}^{2}$ is less than 0.99 , construct the calibration curve again.

\subsection{Checking calibration curves with calibration mixed standards:}

Aspirate calibration check standard solutions (10.2.2,10.2.3 and record the values. The calibration check standards shall read 100 $\pm 5,50 \pm 2.5 \mu \mathrm{g} / \mathrm{l}$ respectively. In case of any deviation, construct the calibration curve again. If the deviation persists, construct a new calibration curve with freshly prepared standards.

\subsection{Analysis of samples:}

Aspirate prepared sample solutions and determine the concentration from the calibration curve. For some trace elements linearity range is less than $50(\mu \mathrm{g} / \mathrm{ml})$. The analysis of samples for such elements shall be carried out within the linear range by diluting the sample to fall within the calibration range. 


\section{Quality Assurance:}

\subsection{Precautions and controls:}

14.1.1 Glassware shall be thoroughly cleaned, rinsed with water, 2\% nitric acid and deionized water prior to use.

14.1.2 Standards shall easily get contaminated. Proper care shall be taken during their preparation and storage.

14.1.3 Samples containing high dissolved solids (e.g. Ground water) may have different viscosity than that of standards and have a different nebulization rate which affects the results. In such cases, the samples shall be diluted.

\subsection{Internal Quality control:}

14.2.1 Quality Checks: A blank and duplicate is included with each batch (typical of 10 samples). Refer Quality Control Procedure (VPR-QP-5.9, Table-2) for the number and type of checks required for the determination of trace elements by ICP.

14.2.2 Issue of check samples: The Quality Manager issues Quality Control Check sample (8.11) as per IQC schedule /when required. The analyst analyzes the samples following the procedure and reports the results to Quality Manager. The Quality Manager reviews the results, enters the results in the control chart for element and analyzes trends.

\subsubsection{External Quality Control:}

The laboratory participates in the proficiency testing program inter laboratory comparison and the results are falling within the specified values. 


\section{References:}

15.1 US EPA 6010b, Inductively Coupled Plasma- Atomic Emission Spectrometry.

15.2 US EPA 200.7, Determination of trace elements in water and waste by ICP OES

15.3 USEPA 3051A, Acid Digestion of Sediments, sludges and Soils for acid extractable/total recoverable metals.

15.4 USEPA 3052, Acid Digestion of Sediments, sludges and Soils.

15.5 Quality Control Procedure (QP-VPR- 5.9) for internal quality control.

15.6 Method validation Data for minerals and heavy metals in soil and sediments.

15.7 Selection and validation of test methods (QP-VPR- 5.4) for performance criteria. 


\section{Appendix D : Contour Maps of Selected Heavy Metals}

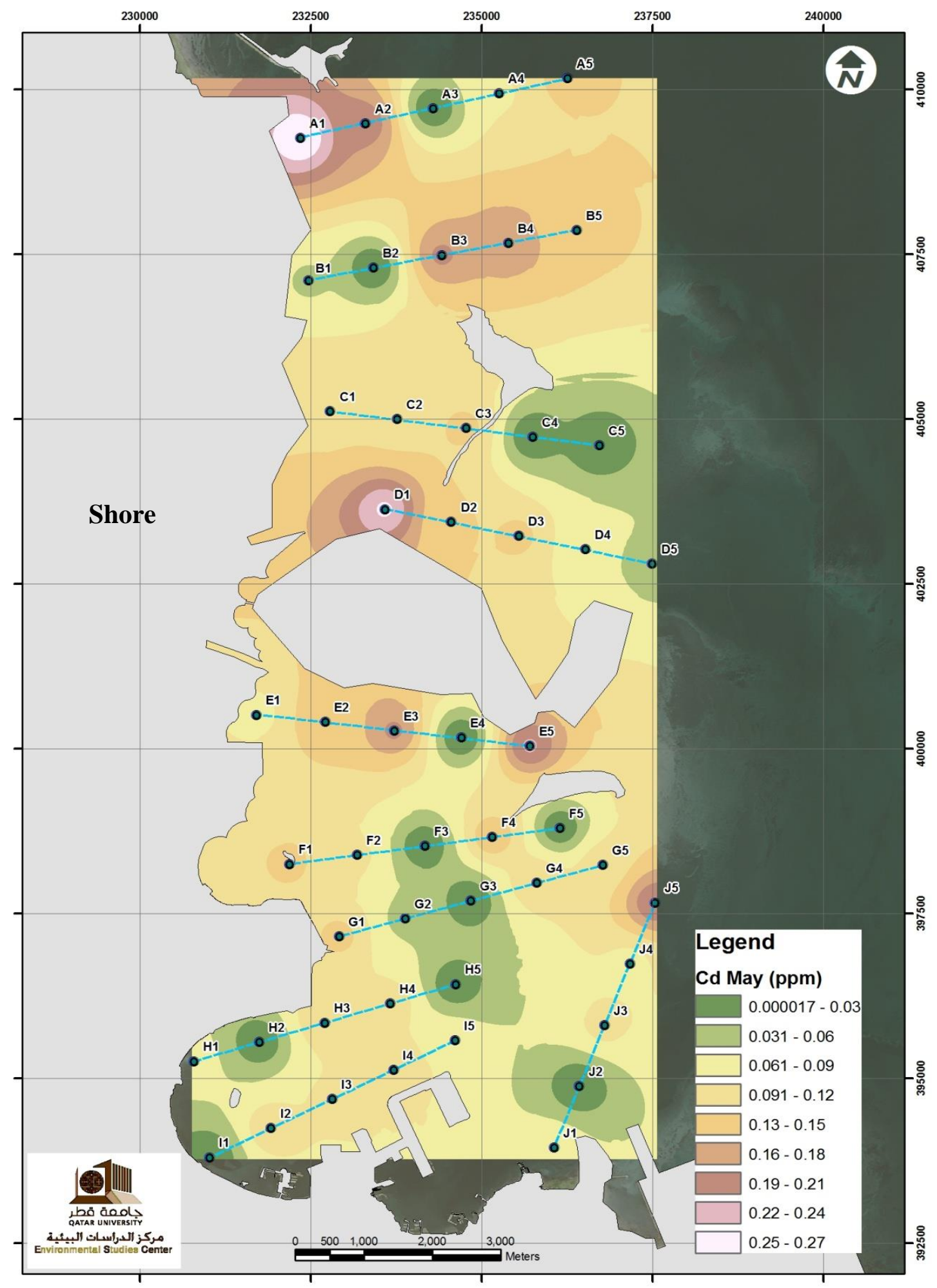

Figure 1: Contour Map showing the distribution of Cadmium metal around Doha Bay during May 2012. 


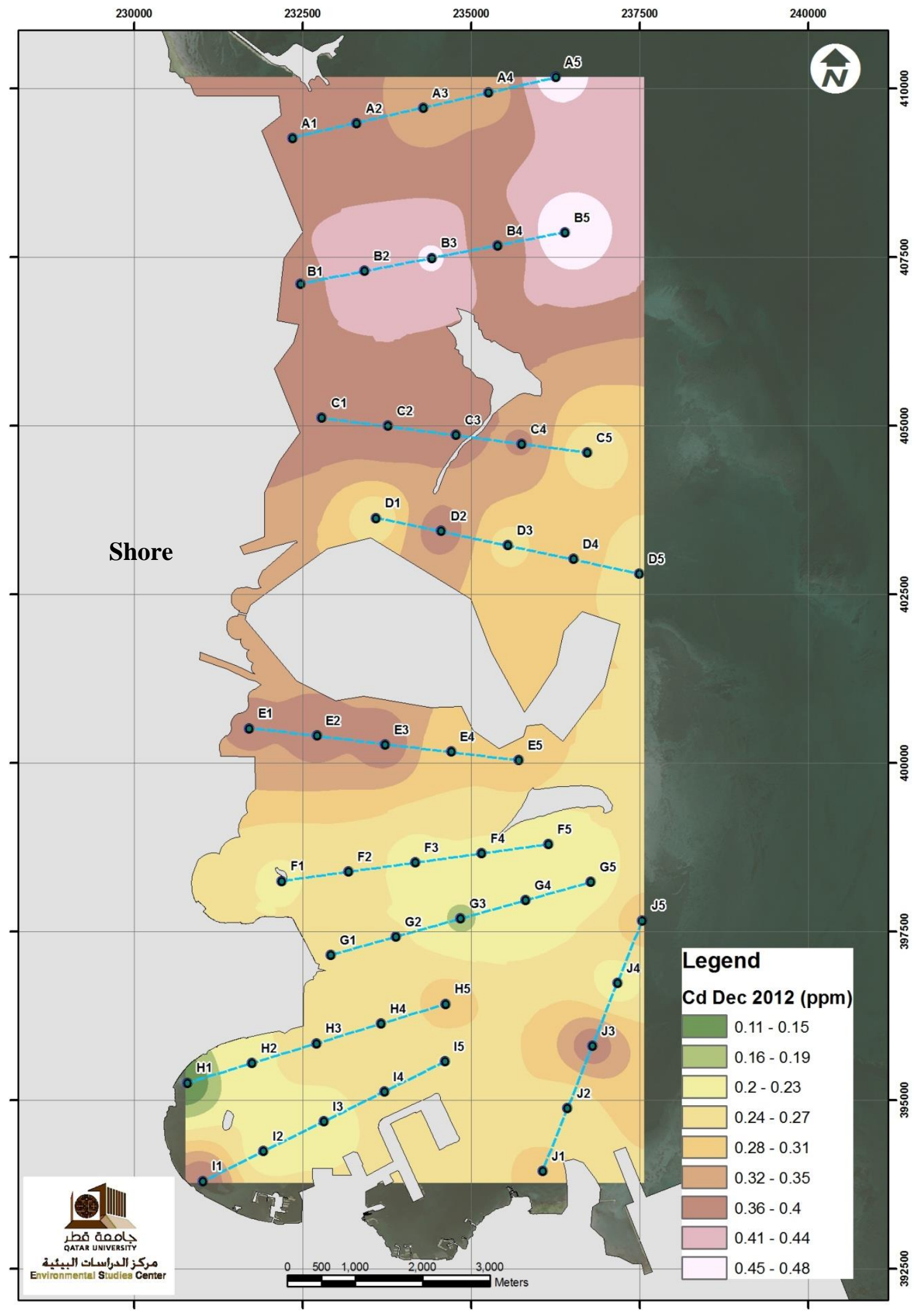

Figure2 : Contour Map showing the distribution of Cadmium metal around Doha Bay during December 2012. 


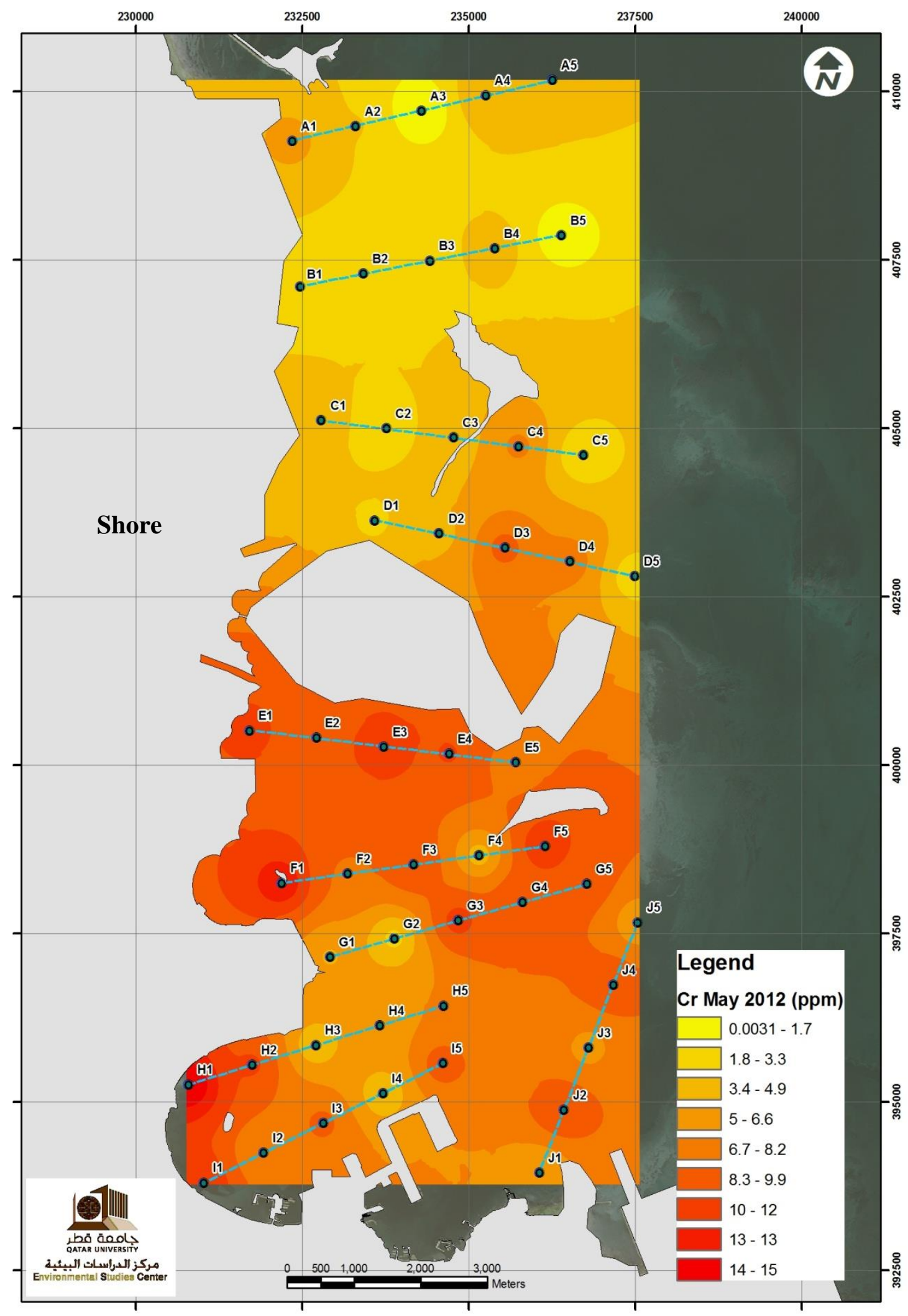

Figure 3: Contour Map showing the distribution of Chromium metal around Doha Bay during May 2012. 


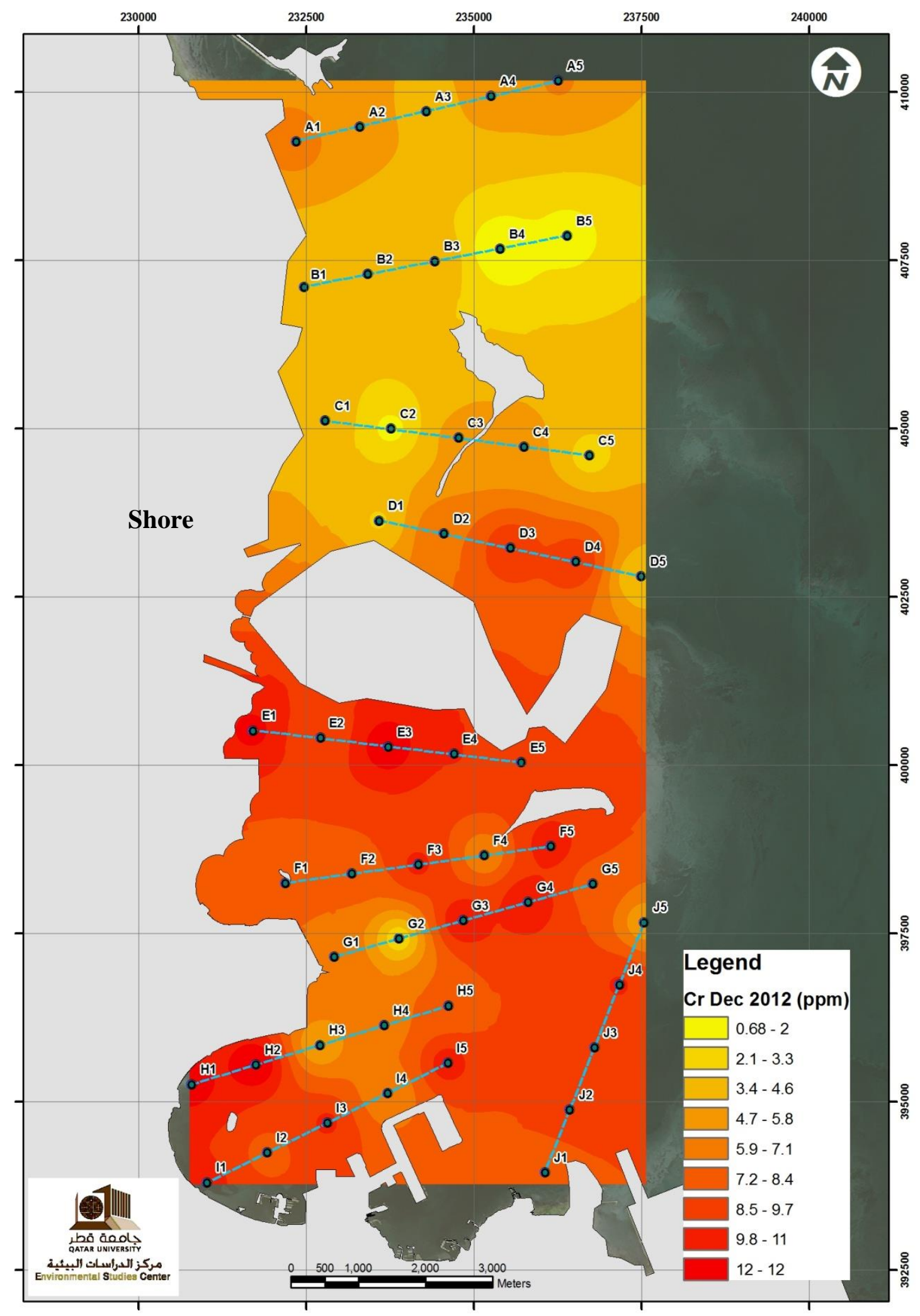

Figure 4: Contour Map showing the distribution of Chromium metal around Doha Bay during December 2012. 


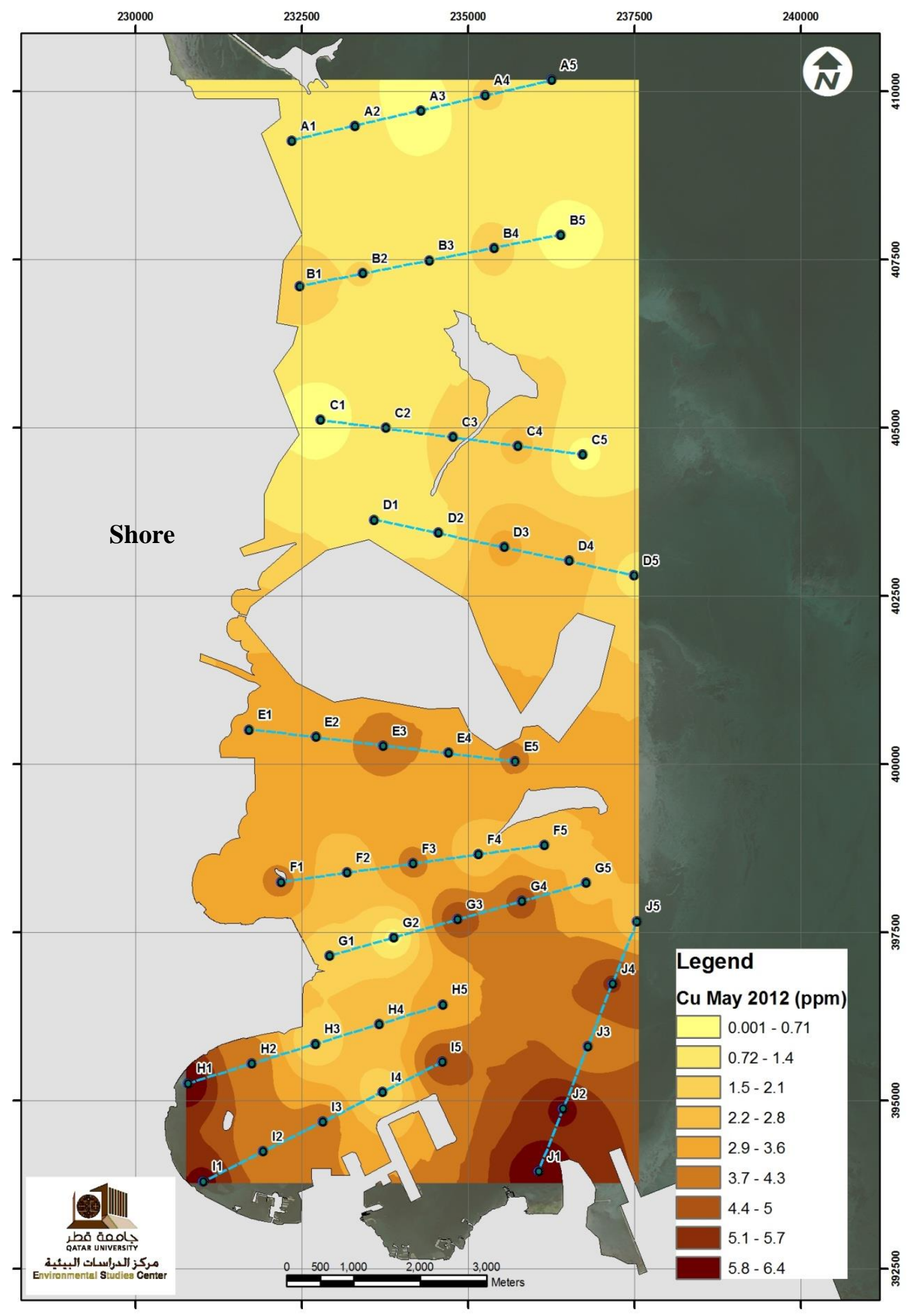

Figure 5: Contour Map showing the distribution of Copper metal around Doha Bay during May 2012. 


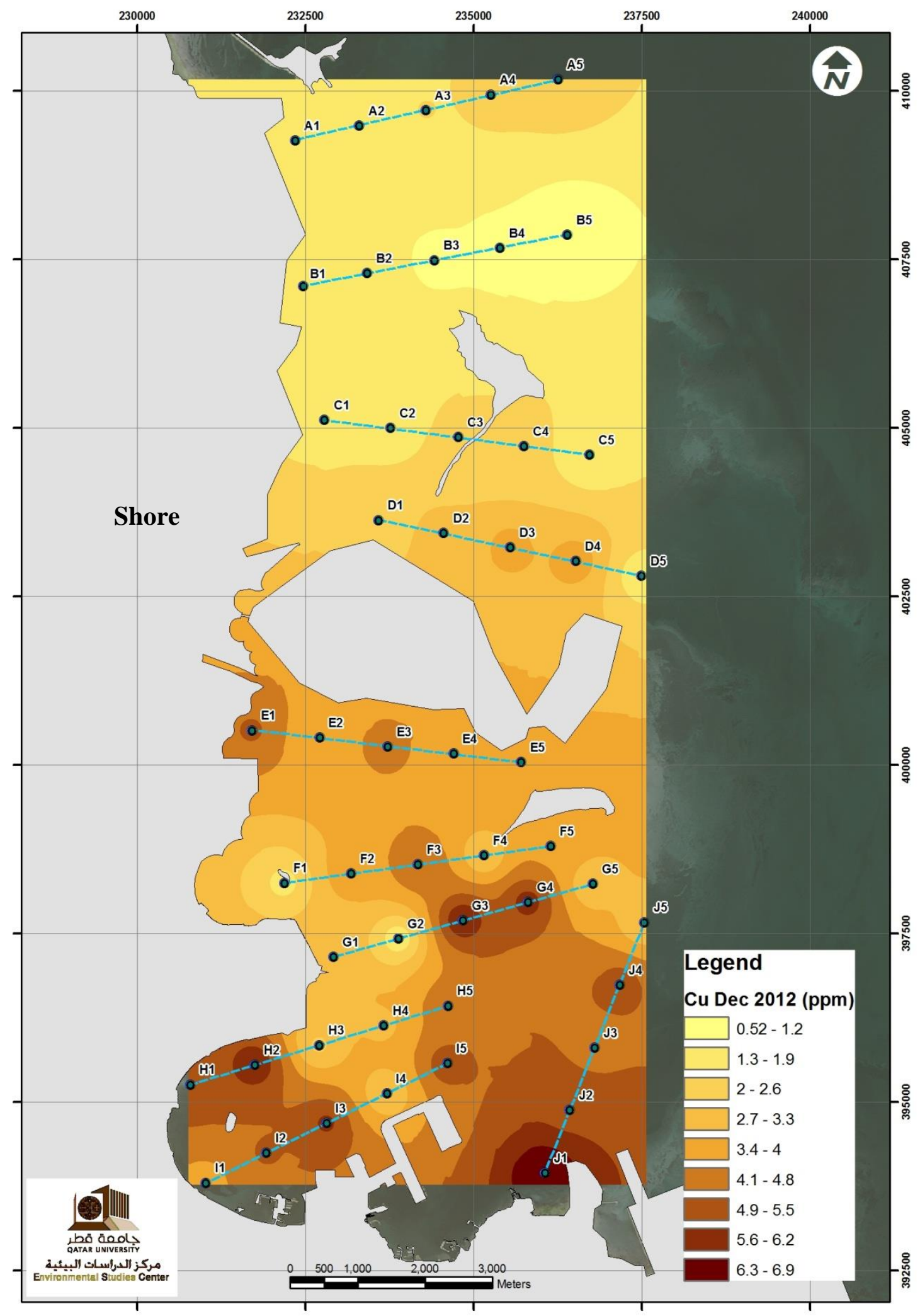

Figure 6: Contour Map showing the distribution of Copper metal around Doha Bay during December 2012. 


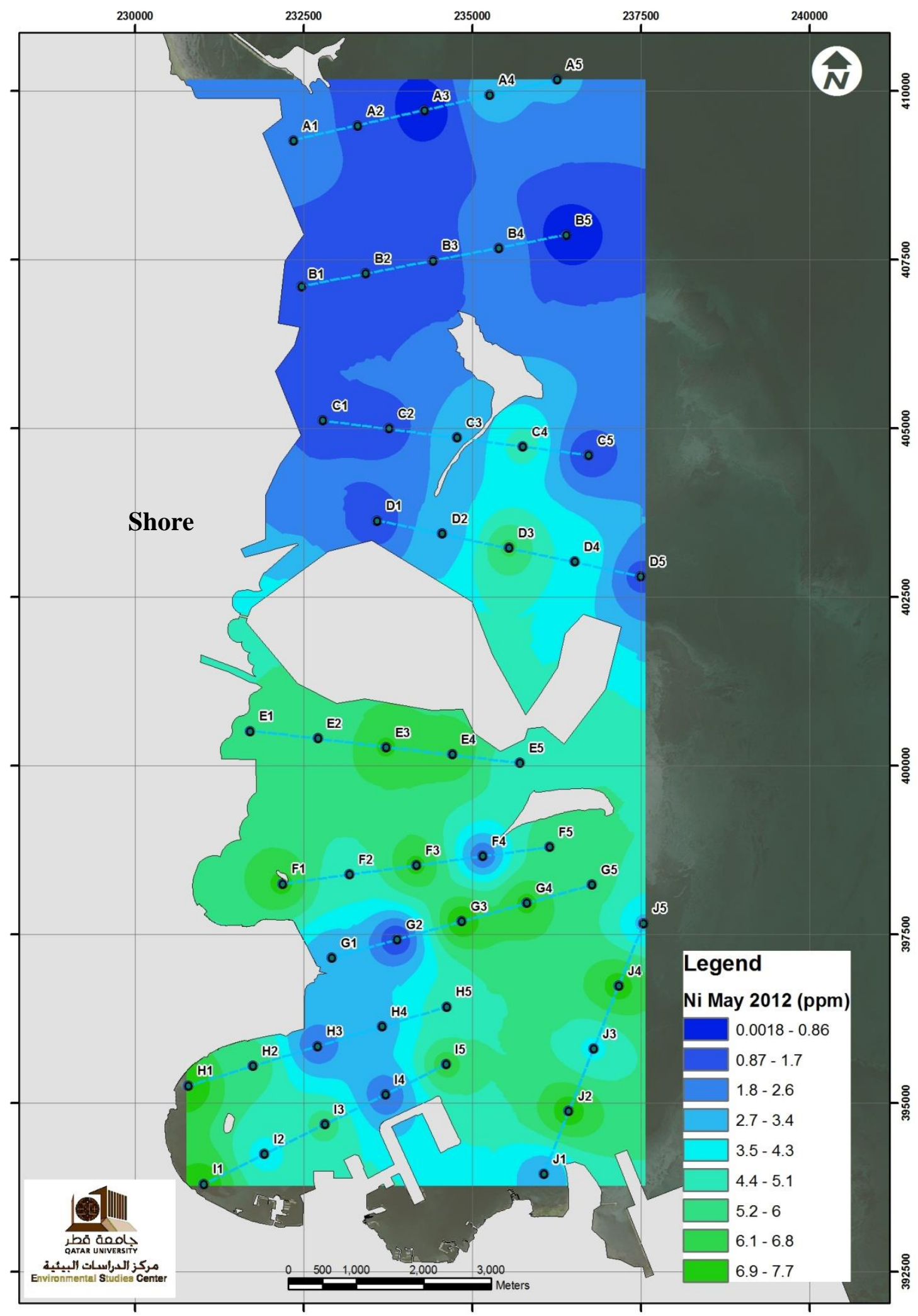

Figure 7: Contour Map showing the distribution of Nickel metal around Doha Bay during May 2012. 


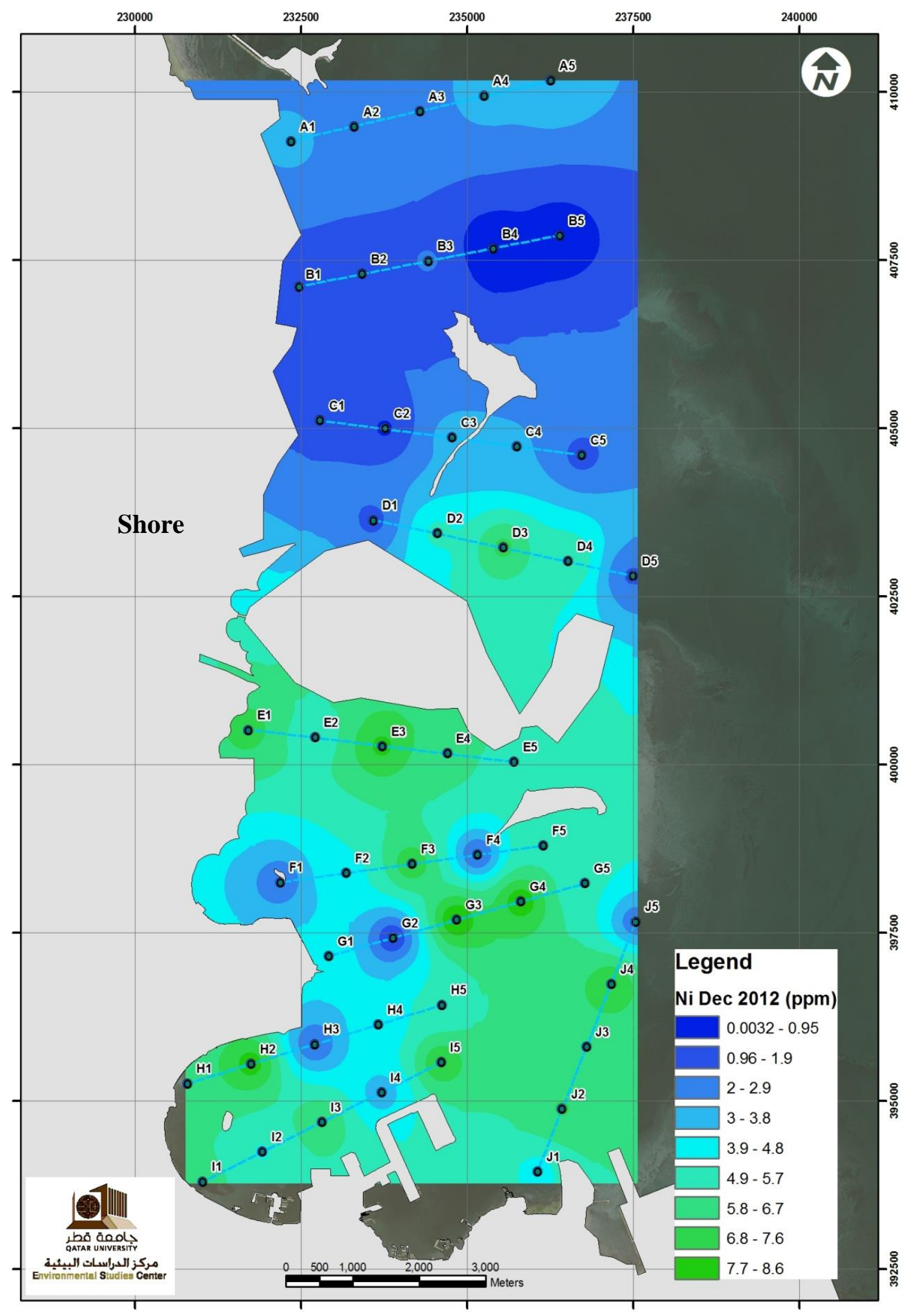

Figure 8: Contour Map showing the distribution of Nickel metal around Doha Bay during December 2012. 


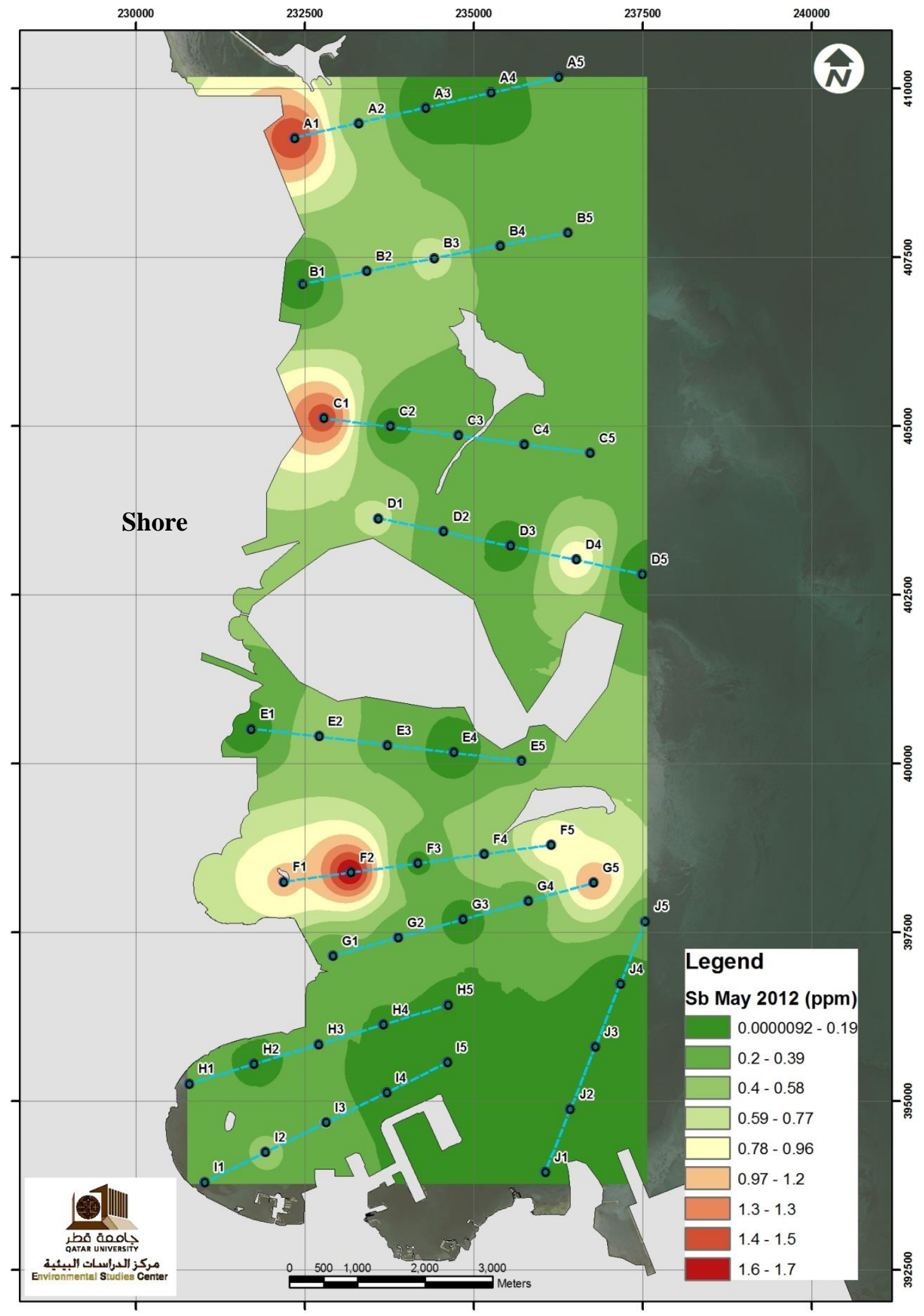

Figure 9: Contour Map showing the distribution of Antimony metal around Doha Bay during May 2012. 


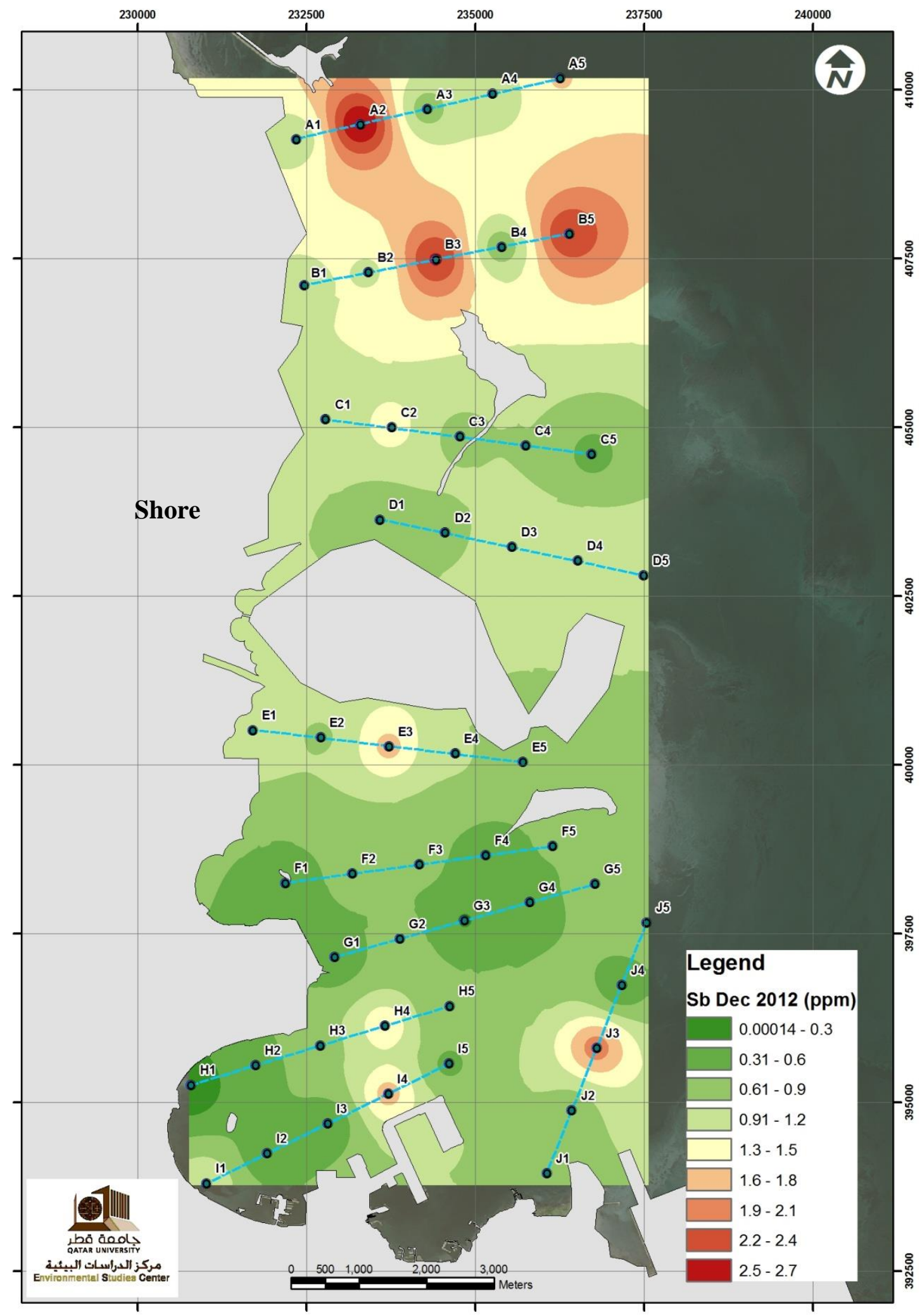

Figure 10: Contour Map showing the distribution of Antimony metal around Doha Bay during December 2012. 


\section{Appendix E : Images of Equipment and Instruments}
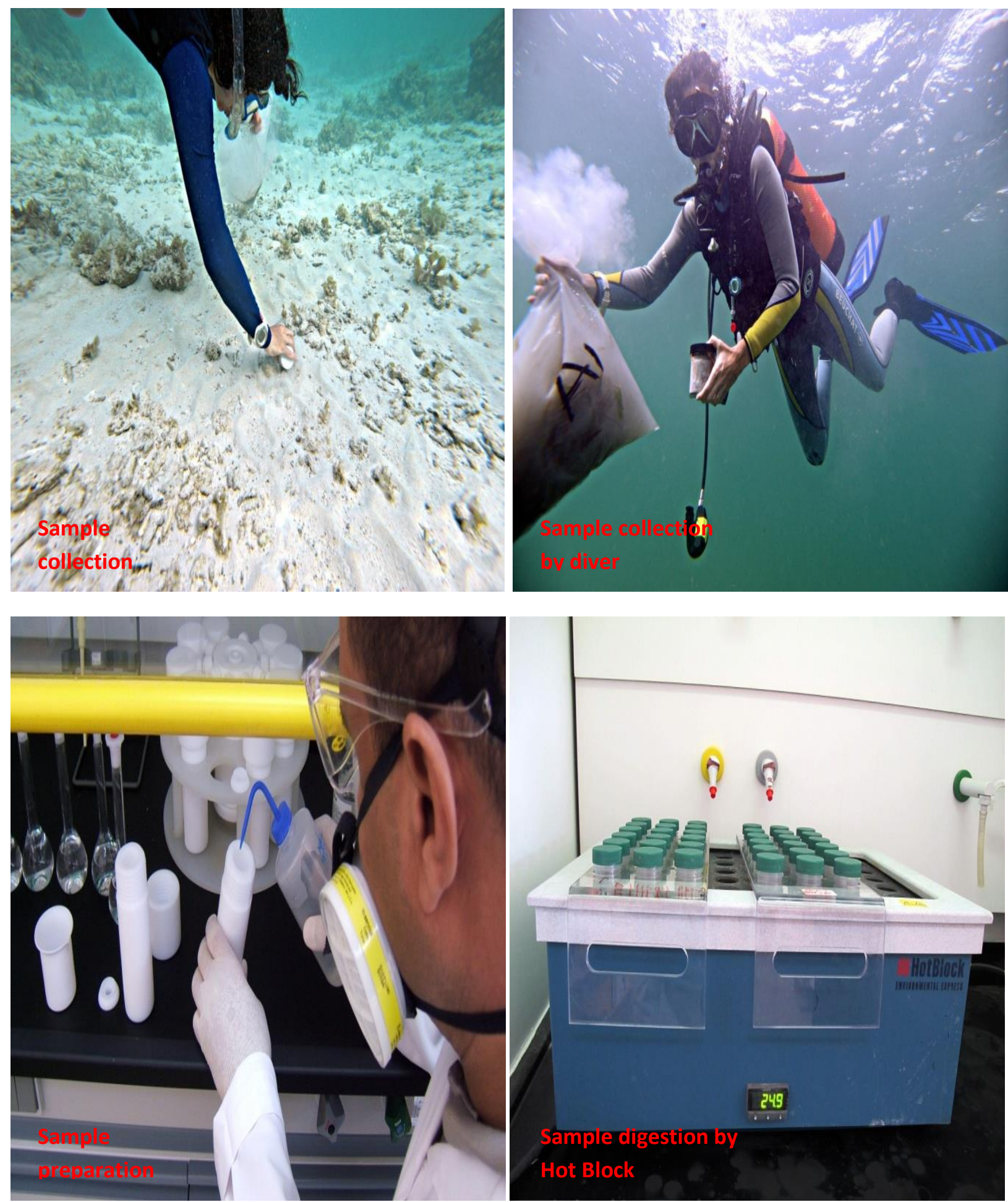
Cont. Appendix C
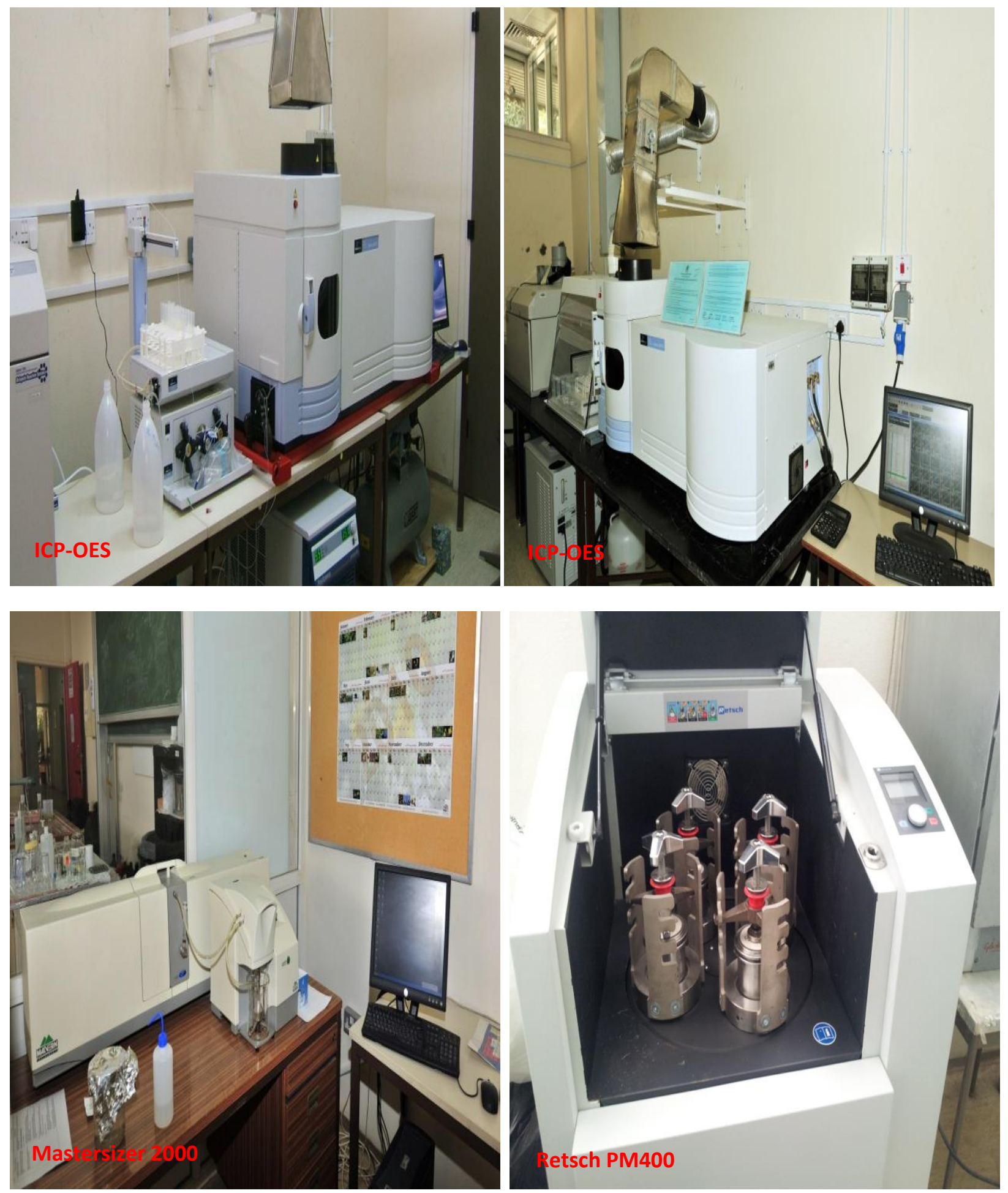